\title{
Safeguarding children: a comparison of England's data with that of Australia, Norway and the United States
}

Emily R. Munro* and Esmeranda Manful* *

*Childhood Wellbeing Research Centre

In association with the **Centre for Research in Social Policy, Loughborough University

Department for Education 
The Childhood Wellbeing Research Centre is a partnership between the Thomas Coram Research Unit (TCRU) and other centres at the Institute of Education, the *Centre for Child and Family Research (CCFR) at Loughborough University and the Personal Social Services Research Unit (PSSRU) at the University of Kent. 
This research report was commissioned before the new UK Government took office on 11 May 2010. As a result the content may not reflect current Government policy and may make reference to the Department for Children, Schools and Families (DCSF) which has now been replaced by the Department for Education (DFE).

The views expressed in this report are the authors' and do not necessarily reflect those of the Department for Education. 


\section{Contents}

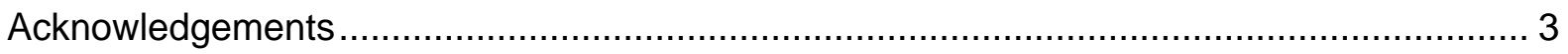

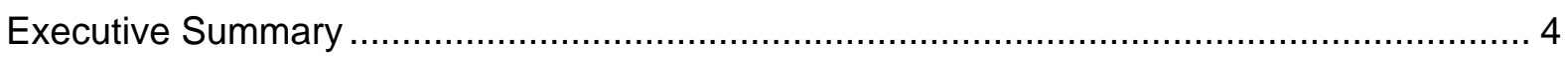

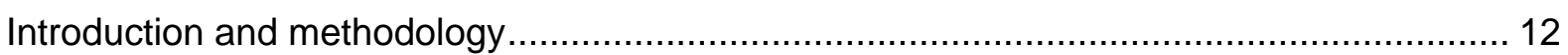

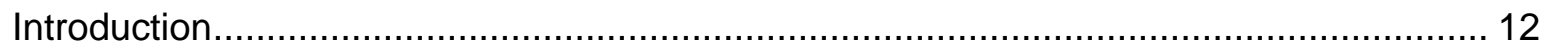

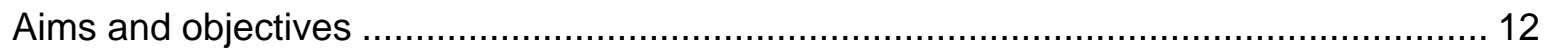

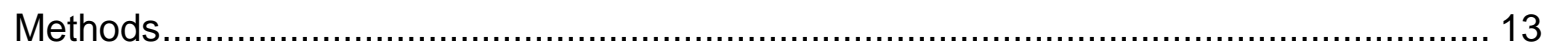

Challenges and limitations of using administrative child welfare data........................... 16

Similarities and differences in child welfare systems and their implications.................... 17

Legal and policy frameworks governing child welfare ............................................. 18

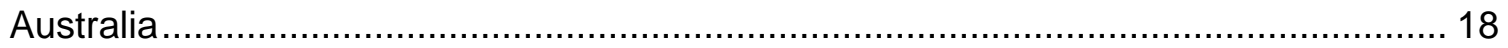

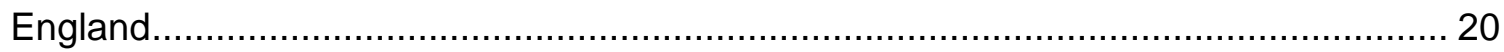

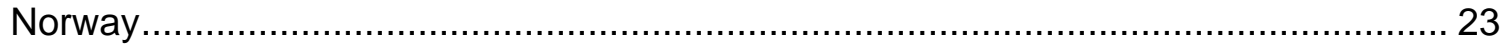

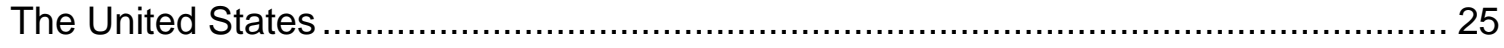

Definitions of abuse and neglect and percentage of children affected by different types of

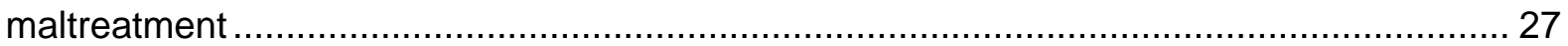

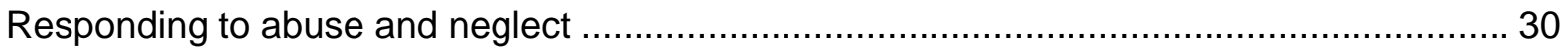

Referrals, assessments and substantiation of abuse and neglect .............................. 30

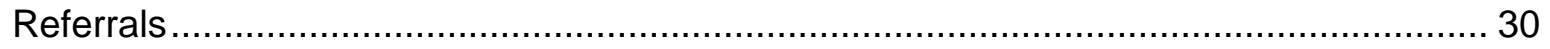

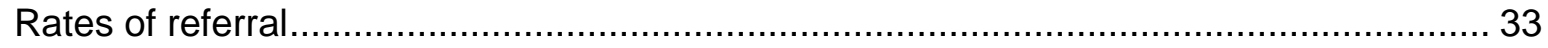

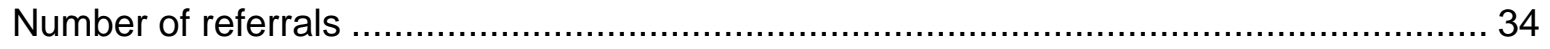

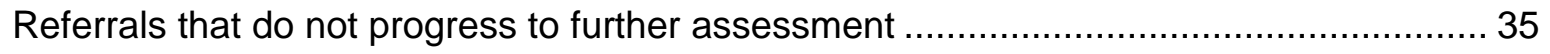

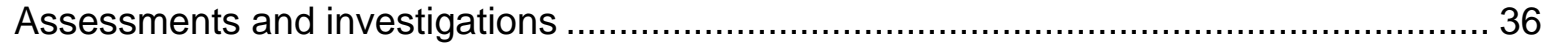

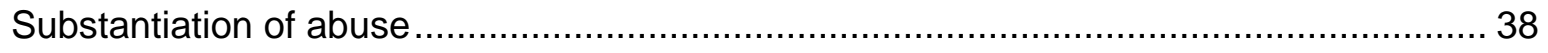

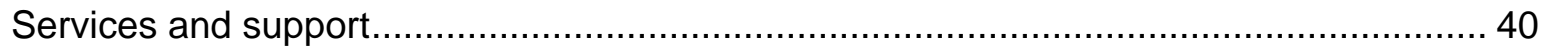

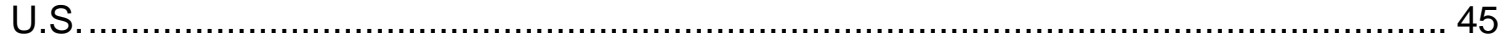

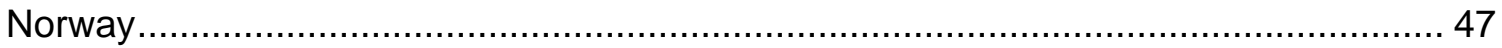

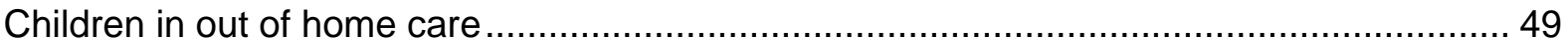

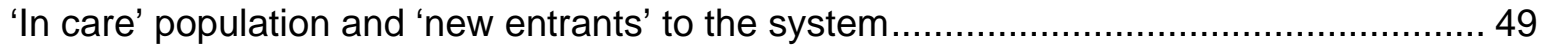

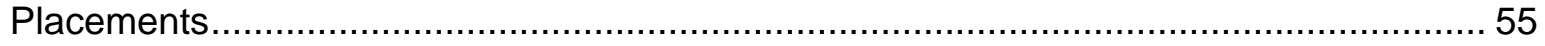

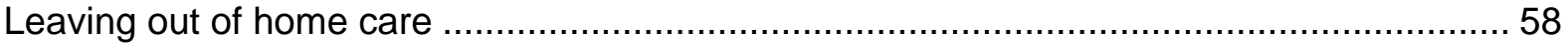

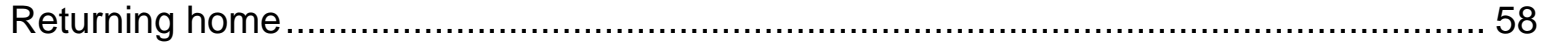

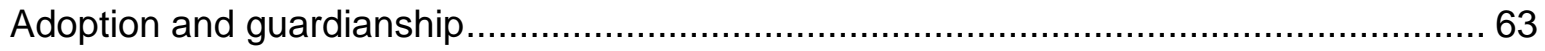

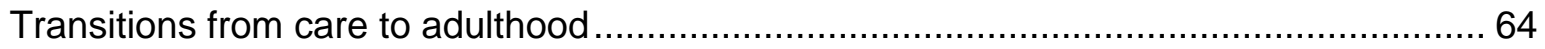

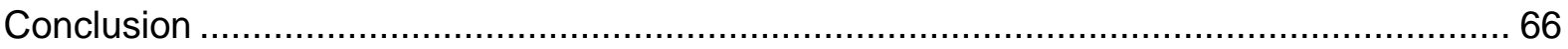


Appendices

\section{Table of tables}

Table 1: Main sources of children's social care services data used for the report.

Table 2: Role of the state vis-a-vis child and family in orientations to child maltreatment: child

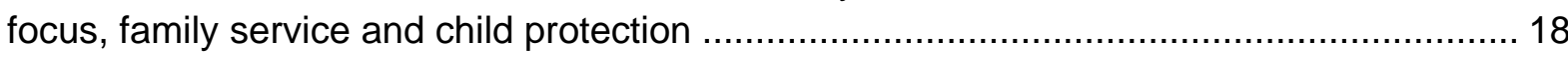

Table 3: Total number of cases referred to children's social care services in a given year.. 32

Table 4: Number of cases of substantiated abuse per year ........................................... 39

Table 5: Number of children by number of services, at 31 March 2010 ............................ 43

Table 6: Number of children by type of services by service provider, at 31 March.............. 44

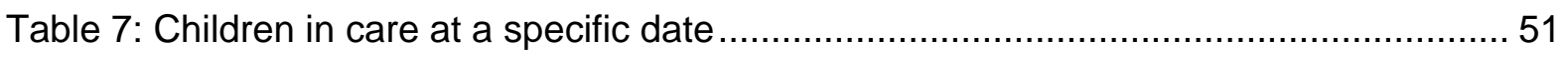

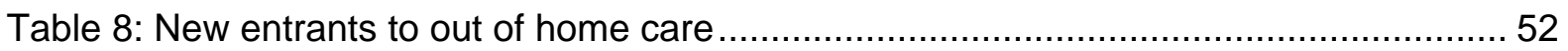

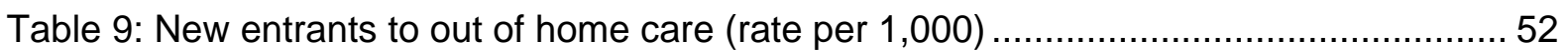

Table 10: Duration of time children remain in out of home care (percentages) ................... 54

Table 11: England: Reason child placement episode ceased during the year ending 31

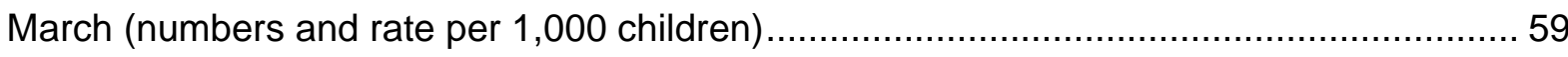

Table 12: U.S: Children Exiting Foster Care During the Financial Year (FY) (numbers and rates per 1,000 children) 


\section{Acknowledgements}

The study was funded by the Department for Education. The authors would like to thank all the members of the Research Advisory Group for their help and support. They would also like to acknowledge the important contribution of an international expert working group including the following members:

- Elisabeth Backe-Hansen (NOVA, Norwegian Social Research)

- Rick Barth (School of Social Work, University of Maryland)

- Tim Beard (Australian Institute of Health and Welfare)

- Leah Bromfield (Australian Centre for Child Protection, University of South Australia)

- Isabella Craig (Department for Education, England)

- John Fluke (Graduate School of Social Work, University of Denver)

- Ilan Katz (Social Policy Research Centre, University of New South Wales)

- Tarja Pösö (Department of Social Work Research University of Tampere Finland)

- Kate Valentine (Australian Institute of Health and Welfare)

We also wish to thank Rebecca Brown for her work on the scoping review that served as the foundation for this report and Harriet Lowe for her administrative support throughout the project. 


\section{Executive Summary}

\section{Introduction}

In recent years increasing attention has been given to the value of cross-national research and analysis to illuminate strengths and weaknesses in child welfare systems (Freymond and Cameron, 2006; Gilbert, Parton and Skivenes, 2011a; Hetherington et al., 1997; Stein and Munro, 2008). International comparisons of child maltreatment may allow policy and practice in one or more countries to be benchmarked against others; and may also assist in the identification of alternative strategies to protect children from harm and promote their welfare (Freymond and Cameron, 2006; Hetherington, et al., 1997; Munro et al., 2005). However, a recent OECD report concluded that:

child maltreatment (abuse and neglect) - has received less attention [than child wellbeing in international comparisons]. This is an important gap since the effect of maltreatment on individual children cannot be understated (OECD, 2011, p.246).

In this context it is valuable to explore the role and contribution that existing datasets may make to understanding variations in the recognition of and responses to abuse and neglect in different jurisdictions.

\section{Aims and objectives}

The Childhood Wellbeing Research Centre (CWRC) was commissioned by the Department for Education to undertake a study with the overarching aim of drawing together existing aggregate administrative data on safeguarding children and child protection and exploring the availability and comparability of these data as a tool for comparing England's performance against that of other countries. The objective was to consider how different institutional and cultural approaches alongside different forms of provision and support may influence rates of abuse and neglect and the responses of public authorities. The study:

1) reviews the literature on child welfare data and recent policy and practice developments in England, Australia, Norway and the United States (U.S.);

2) offers analysis and interpretation of the aggregate administrative data available in the countries above to explore changes in recognition of, and responses to, abuse and neglect over time;

3) maps changes in responses to children coming to the attention of child welfare agencies against significant events and key policy and practice developments; and 
4) examines the strengths and limitations of relying on administrative datasets to compare England's child welfare policy and practice with other countries and key issues that need to be taken into account when interpreting these data.

The study builds on a scoping review on the availability and comparability of child injury and safeguarding data collected and published (in English) in a sample of developed countries ${ }^{1}$, (Munro et al., 2011a) as well as a review of the comparability of statistical returns in England, Wales, Scotland and Northern Ireland (Munro, Brown and Manful, 2011).

\section{Methods}

Published aggregate administrative data ${ }^{2}$ on children coming to the attention of children's social care services during the period 1999-2010 have been collated for England, Australia, Norway and the U.S ${ }^{3}$. These countries were purposively selected because preliminary research demonstrated that they collected sufficient administrative aggregate data to facilitate comparisons and because of the orientation of their child welfare systems; the sample includes countries that have historically been categorised as operating a child protection approach and those operating a family or welfare orientated approach (see below for further details).

In recognition of the importance of interpreting quantitative data with reference to similarities and differences in social, political, legal and economic frameworks and policy and practice developments a scoping review of the literature was undertaken. In addition, an international working group of academics and data experts was established to verify the accuracy and interpretation of the administrative data and to explore trends and developments over time.

\section{Key findings}

Challenges and limitations of using aggregate administrative datasets

- The datasets supply data on children who come to the attention of children's social care; these children and young people reflect the tip of the iceberg as harm may go unrecognised or unreported (Gilbert et al., 2009a; Davies and Ward, 2012).

- The information countries choose to collect on child maltreatment varies. There are also differences in what is routinely published and thus what can be compared.

\footnotetext{
1 A wider range of data items may be collected but these are not necessarily accessible to the public.

2 The study did not examine relative expenditure data.

3 This approach means that rounded figures have been used throughout. Initially the research team had also planned to collate data from New Zealand but was not able to as these data are not publically available (see p. 16 for further details).
} 
- Differences in definitions of maltreatment, thresholds for action, child protection processes and recording conventions mean that data from different countries or jurisdictions may not be comparable (Bromfield and Higgins, 2004; ChildOnEurope, 2009; ISPCAN, 2010; Munro et al., 2011a; Munro, Brown and Manful, 2011).

Similarities and differences in child welfare systems and their implications

- Typologies of child welfare systems assist in understanding similarities and differences in the number of children who come to the attention of statutory children's social care services and subsequent service responses to meet their needs.

- In the 1990s Anglo-American countries including England, the U.S. and Canada were classified as adopting a child protection approach whereas Nordic and Continental European countries were classified as adopting a family service approach (Gilbert, 1997; Gilbert et al., 2009a; Hetherington et al., 1997).

- Countries adopting a child protection orientation tend to view child protection as distinct from a wider continuum of services for children with lower levels of need, to delay intervention and adopt a more legalistic approach. In contrast the family service approach is essentially needs based; child protection investigations are seen as part of a continuum of services for children in need and their families, and agencies respond to allegations of maltreatment alongside referrals for family support services for children who may be in need but not likely to suffer significant harm.

- Policy and practice developments have served to challenge traditional ideologies and orientations (Gilbert, Parton and Skivenes, 2011). Gilbert and colleagues (2011) suggest that as countries have sought to strike a new balance between child protection and family services a new orientation has emerged which is child-focused and the object of concern is the child's overall wellbeing and development.

Definitions of abuse and neglect and percentage of children affected by different types of maltreatment

- There is greatest definitional ambiguity at an international level concerning neglect and emotional abuse. These two types of maltreatment accounted for between $49 \%$ (Australia) and $54 \%{ }^{4}$ (England) of identified cases of maltreatment in 1999; and 64\% (Australia) and $72 \%$ (England) in $2010^{5}$.

\footnotetext{
${ }^{4}$ In England in 1999 if mixed categories of abuse applied then each category of abuse was recorded. Therefore, the percentage cited is the percentage of recorded categories of abuse rather than the percentage of cases.

${ }^{5}$ Percentages have been rounded.
} 
- Data reveal that in England, Australia, and the U.S. the majority of maltreated children ${ }^{6}$ are now classified under the category of neglect (England and the U.S.) or emotional abuse (Australia) ${ }^{7}$.

- In the last decade there has been an increase in the percentage of children categorised under emotional abuse in England, Australia and Norway. This appears to reflect increasing recognition of the detrimental impact of this form of abuse on children's wellbeing and development and corresponding efforts to promote improved recognition and responses through changes in reporting triggers or legislation.

\section{Referrals}

- England has a high but stable referral rate (at around 50 per 1,000 children) when compared to both Australia and the U.S. In interpreting these data it is important to note that in England referrals include requests for services thus inflating figures relative to the U.S. where referrals are concerned with allegations of maltreatment.

- In the U.S rates have ranged from a low of 35.9 in 2002 to a high of 44.1 in 2008; since 2004 rates have been fairly constant. In contrast, Australia's referral rate had increased significantly over the last ten years from 23.6 per 1,000 in 1999 to 67 in 2009 and declining to 56.2 in 2010.

- In Norway between 1994 and 2008 there was a year on year increase in referrals investigated per 1,000 children; from 13.2 in 1994 to 25.2 in 2008. Consistent with the Nordic family services child welfare orientation, investigations are not limited to concerns regarding child protection. Over half of cases open to investigation are triggered by 'conditions in the home'.

- In general, data on numbers of referrals show an upward trend in each country between the late 1990s and 2010.

- Between 1999 and 2009 notifications in Australia more than tripled from 103,302 to 339,454 . Child welfare statistics and enquiries into child protection assisted in raising awareness that the Australian child welfare system was overburdened and that considerable resources were being invested in referral and assessment rather than support services and interventions (Bromfield and Katz, personal communication; Council of Australian Governments, 2009; Holzer and Bromfield, 2008). In recent years policy initiatives have been implemented that aim to re-focus the system on prevention and early intervention and these have contributed to the sharp decline in

\footnotetext{
${ }^{6}$ Substantiated cases in Australia and the U.S., children who are the subject of a child protection plan in England and children placed under protection in Norway.

${ }^{7}$ There are variations between territories; in Western Australia and the Northern Territory neglect was the most commonly substantiated maltreatment type in 2009-10 (AlHW, 2011; Lamont, 2011).
} 
notifications (Australian Research Alliance for Children and Youth, 2008; Wood inquiry, 2008).

- In England between 2002 and 2010 there was a steady decline in the percentage of referrals that resulted in no further action, from $54 \%$ in 2002 to $34 \%$ in 2010 . This could reflect improvements in recognition and responses to safeguarding concerns amongst professionals resulting in more appropriate referrals; or that social workers have progressed more cases to initial assessment because of anxiety within the system

- The percentage of referrals that were 'screened' out of the U.S. child welfare system remained fairly consistent over time at around 40\%. In Australia there have been fluctuations in the percentage of referrals perceived not to require further action; more than $55 \%$ of referrals resulted in no further action (2002-2004).

\section{Assessments and investigations}

- Difficulties are encountered drawing meaningful comparisons between data on assessments due to differences in the processes undertaken and thresholds for instigating them.

- Overall the rate of assessment appears to have been on the rise in every country since 1999; although in Australia proactive efforts have been made to try and respond to difficulties encountered as a result of the $18.9 \%$ annual increase in the rate of change in the number of assessments undertaken during the period 2003-7.

- There are similarities in expectations of when initial assessments in England and investigations in Norway should be undertaken. In both countries assessments are undertaken if it is considered that the child may be a child in need (which includes children with special needs or disabilities) and requires services (section 17, Children Act 1989; section 4.4, Child Welfare Act 1992). Data reveal that the rate of assessments in both countries has been on the increase but overall England has the highest rate, which stood at 35.9 per 1,000 in 2010 compared to 29.5 per 1,000 in Norway.

\section{Substantiation of abuse}

- In the U.S. both the number of cases and rate of substantiation per 1,000 children have fallen since 1999 (488,073 and 7 per 1,000 in 1999 compared to 443,005 and 5.9 per 1,000 in 2009). The implementation of differential responses in 20 States 
may have contributed to this (Berrick, 2011) ${ }^{8}$. In Australia a more changeable picture emerges with fluctuations in numbers and rates of substantiation over the past ten years. Since 2005 the rate of substantiation has been falling and stood at 6.1 per 1,000 children in 2010 . One reason for this may be implementation of programmes such as Brighter Futures, a child protection prevention programme which is targeted at families most at risk of entering the child protection system (Wood, 2008).

- In England the total number of children who were the subject of a child protection plan declined gradually from 1999 to $2005^{9}$ (annual rate change of $-1.2 \%$ ). Since then there has been a year on year increase in the number of children who have become the subject of a child protection plan.

\section{Out of home care}

- There has been an upward trend in the number of children in out of home care over the period 1999-2010 in every country except the U.S. (where there was a decline from 567,000 in 1999 to 408,452 in 2010).

- The stock population in Australia more than doubled over the period from 15,674 in 1999 to 35,895 in 2010, whereas in England numbers increased fairly gradually in the period 1999-2005, fell slightly in 2006-8 before an unprecedented increase in the wake of media attention surrounding the Peter Connelly case.

- In Norway, despite heavy investment and a marked increase in the provision of assistance or in-home services the care population has risen by $48 \%$ in the past ten years.

- Although each country operates in a unique social, political and economic context in 2006-7 the rate per 1,000 of children in out of home care in England, Australia and Norway converged at around five per 1,000.

- Data on new entrants to out of home care reveals a different picture to that on the in care population and illustrates that the rate of new entrants to out of home care is much lower in Norway than elsewhere (0.5 in 2007 compared to 2.2, 2.8 and 3.7 in England, Australia and the U.S. respectively) but that children tend to stay longer. One reason for this is that in Norway maintaining the blood tie between biological parents and children is presumed to be a moral and legal right and therefore adoption is rarely used (Skivenes, 2011; Weyland, 1997).

\footnotetext{
${ }^{8}$ Under this alternative system families reported for child maltreatment and identified as low to moderate risk are offered an assessment rather than an investigation and notions of substantiation are eliminated when possible and appropriate (Berrick, 2011).

${ }^{9}$ With the exception of 2003.
} 
- In each of the four countries under review foster care has been the most common placement type since 1999. In 2010 between 73 and 92 percent of children were in foster placements. However, there are marked differences in the proportion of children in care placed with relatives, kinship carers or friends: 11\% in England, 25\% in the U.S. and $46 \%$ in Australia, although in each of these countries as well as Norway there have been policy initiatives designed to promote the use of these placements.

- In both England and the U.S. efforts have been made to promote permanency for children who cannot safely return home. Since 2002 the adoption rate per 1,000 children in the U.S. has remained stable at 0.7. A similar pattern emerges in England. The Adoption and Children Act 2002 aimed to improve planning for permanence and increase the number of children adopted from care (Department of Health, 2000). Although there was a small increase in the number of children adopted from care in 2003-2005 the rates per 1,000 children adopted have remained constant at 0.3.

- Guardianship offers an alternative permanence arrangement to adoption for children who cannot return home; in the U.S. between 3 and 7 percent of children exiting care, leave under these arrangements. Since its implementation in England in 2005, the number of children who achieve permanence through this means has increased; in 2010,5 percent $(1,260)$ of children ceased to be looked after when a Special Guardianship Order was granted.

\section{Conclusion}

In the last decade both central and local administrations in England, Australia, Norway and the U.S. have implemented multiple reforms and programmes that have served to change the structure and delivery of services aimed at safeguarding children from harm and promoting their welfare. Routinely collected child maltreatment datasets offer a readily accessible source of data to assist in exploring similarities and differences in recognition of and responses to abuse and neglect and how these have changed over time. However, the study highlights that variations in the data collected, recording practices, definitions of abuse and neglect, thresholds for formal intervention by children's social care services and subsequent systems and processes to respond to these concerns make drawing meaningful comparisons challenging. That said the analysis serves to highlight an upward trend in referrals, assessments and in the out of home care population in England, Australia and Norway, even though reforms have been implemented to promote early intervention and prevention. In contrast, in the U.S there has been a decline in the number of cases of substantiated abuse and in the number of children in out of home care. Reasons for this 
include an increase in the use of 'voluntary' or informal kinship care which diverts children from the formal child welfare system. In addition, efforts have been made to promote timely permanence via adoption or legal guardianship ${ }^{10}$ for children who cannot return to live with their birth parents (Berrick, 2011; Gilbert, 2012).

${ }^{10}$ The transfers the child's custody from the state to relatives (Gilbert, 2012). 


\section{Introduction and methodology}

\section{Introduction}

In recent years increasing attention has been given to the value of cross-national research and analysis to illuminate strengths and weaknesses in child welfare systems (Freymond and Cameron, 2006; Gilbert, Parton and Skivenes, 2011a; Hetherington,et al., 1997; Stein and Munro, 2008). International comparisons of child maltreatment may allow policy and practice in one or more countries to be benchmarked against others; and may also assist in the identification of alternative strategies to protect children from harm and promote their welfare (Freymond and Cameron, 2006; Hetherington, 1997; Munro et al., 2005). However, it has also been recognised that:

child maltreatment (abuse and neglect) - has received less attention [than child wellbeing in international comparisons]. This is an important gap since the effect of maltreatment on individual children cannot be understated (OECD, 2011, p.246).

Administrative datasets on children in contact with children's social care services are a 'convenient and inexpensive source for examining policy relevant questions on a longitudinal as well as cross-sectional basis' as they also offer large datasets to facilitate accurate population estimates (Yampolskaya and Banks, 2006, p.343; see also, Drake and JohnsonReid; English, Brandford and Coghlan, 2000; Fluke et al., 2000). In this context it is valuable to explore the role and contribution that existing datasets may make to understanding variations in the recognition of and responses to abuse and neglect in different jurisdictions. This is of particular interest given that there have been shifts in policy and practice in recent years and these data have the potential to facilitate exploration of changes in service responses within and between different countries.

\section{Aims and objectives}

The Childhood Wellbeing Research Centre (CWRC) was commissioned by the Department for Education to undertake a study with the overarching aim of drawing together existing aggregate administrative data on safeguarding children and child protection and exploring the availability and comparability of these data as a tool for comparing England's performance against that of other countries. The objective was to consider how different institutional and cultural approaches alongside different forms of provision and support may influence rates of abuse and neglect and the responses of public authorities. The study: 
1) reviews the literature on child welfare data and recent policy and practice developments in England, Australia, Norway and the United States (U.S.);

2) offers analysis and interpretation of the aggregate administrative data available in the countries above to explore changes in recognition of, and responses to, abuse and neglect over time;

3) maps changes in responses to children coming to the attention of child welfare agencies against significant events and key policy and practice developments; and

4) examines the strengths and limitations of relying on administrative datasets to compare England's child welfare policy and practice with other countries and key issues that need to be taken into account when interpreting these data.

The study builds on a scoping review of the availability and comparability of child injury and safeguarding data collected and subsequently published in English in a sample of developed countries $^{11}$, (Munro et al., 2011a) as well as a review of the comparability of statistical returns in England, Wales, Scotland and Northern Ireland (Munro, Brown and Manful, 2011).

\section{Methods}

At the outset five countries, England, Australia, New Zealand, Norway and the U.S. were selected for the study. They were purposively selected because preliminary research demonstrated that they collected sufficient administrative aggregate data to facilitate comparisons $^{12}$ and because of the orientation of their child welfare systems; the sample includes countries that have historically been categorised as operating a child protection approach and those operating a family or welfare orientated approach (see p.18 for further details). However, data from New Zealand have not been presented for two reasons. Firstly, although a wealth of child protection data are collected in New Zealand much of this is not published. Secondly, it did not prove possible to gain the views and perspectives of academic and data experts on trends in the data that were available. These difficulties highlight the challenges of international comparison and the difficulties of accessing data even when it is collected. Overall, this meant that insufficient data were publically available to facilitate meaningful comparison of the trends in New Zealand compared to other sample countries.

In recognition of the importance of interpreting quantitative data with reference to similarities and differences in social, political, legal and economic frameworks and policy and practice developments a scoping review of the literature was undertaken. Key bibliographic

\footnotetext{
${ }^{11} \mathrm{~A}$ wider range of data items may be collected but these are not necessarily accessible to the public.

${ }^{12}$ The study did not examine relative expenditure data.
} 
databases were searched, including: ArticleFirst (OCLC), ASSIA, Applied Social Sciences Index and Abstracts (CSA Illumina), Social Services Abstracts (CSA Illumina), Sociological Abstracts (CSA Illumina), Web of Science and Zetoc. Articles were also sought on the role and contribution of administrative aggregate datasets as a means of understanding demand for services and the populations receiving child welfare provision. The administrative aggregate data on referrals, investigations, substantiations, service provision and children in out of home care in each country were collated from routinely accessible datasets or reports for the period $1999-2010^{13}$. In addition, an international expert working group was established. This was comprised of leading child welfare academics and data experts in each country. Conference calls were undertaken with members of the group to verify the accuracy and interpretation of the data and to explore trends and developments over time. The contributions of these experts promoted a more nuanced understanding of similarities and differences in the data within the wider policy context. Table 1 below outlines the main sources of children's social care data analysed in the report ${ }^{14}$. Details on the population estimates used for calculations are provided in Appendix 2.

\footnotetext{
${ }^{13}$ With more time and resources it might have been possible to seek access to child level data which can be used to undertake more complex analysis of children and young people's care pathways (Holmes and Thoburn, 2011; McDermid, 2008). However, it remains valuable to see what use can be made of existing published data that are routinely available and freely accessible. This may be particularly useful to respond to or refute the accuracy of media reports on child welfare issues or to offer insight into priority issues on the policy agenda.

${ }^{14}$ England had published data for the year ending $31^{\text {st }}$ March 2011 by study completion but this was not included in analysis as 2010 - 2011 data were not available for all sample countries.
} 
Table 1: Main sources of children's social care services data used for the report

\begin{tabular}{|c|c|c|}
\hline & $\begin{array}{l}\text { Department } \\
\text { responsible }\end{array}$ & Main statistical publications on children's social care services \\
\hline England & $\begin{array}{l}\text { Department for } \\
\text { Education, } \\
\text { England }\end{array}$ & $\begin{array}{l}\text { Department for Education (1999-2009) Referrals, Assessments and } \\
\text { Children and Young People who are the subject of a Child Protection } \\
\text { Plan. Available at: } \\
\text { http://www.education.gov.uk/rsgateway/catego.shtml\#m9 } \\
\text { Department for Education (2010) Children In Need in England, inc/uding } \\
\text { their characteristics and further information on children who were the } \\
\text { subject of a child protection plan (Children in Need census, Final). } \\
\text { Available at: } \\
\text { http://www.education.gov.uk/rsgateway/DB/STR/d000970/index.shtml } \\
\text { Department for Education (1999-2010) Children Looked After by Local } \\
\text { Authorities in England (including adoption and care leavers) year ending } \\
31 \text { March. Available at: Health, Well-being and Care } \\
\text { http://www.education.gov.uk/rsgateway/catego.shtml\#m9 }\end{array}$ \\
\hline Australia & $\begin{array}{l}\text { Australian } \\
\text { Institute of Health } \\
\text { and Welfare } \\
\text { (AlHW) }\end{array}$ & $\begin{array}{l}\text { Australian Institute of Health and Welfare (AIHW). Child protection } \\
\text { Australia (1998/99-2009/10 reports). Available at: } \\
\text { http://www.aihw.gov.au/child-protection-publications/ }\end{array}$ \\
\hline Norway & $\begin{array}{l}\text { Statistics Norway } \\
\text { on behalf of the } \\
\text { Ministry of } \\
\text { Children and } \\
\text { Family Affairs }\end{array}$ & $\begin{array}{l}\text { Statistics Norway (2000 - 2009), Child Welfare. Available at: } \\
\text { http://www.ssb.no/barneverng_en/. }\end{array}$ \\
\hline U.S. & $\begin{array}{l}\text { The Children's } \\
\text { Bureau }\end{array}$ & $\begin{array}{l}\text { U.S. Department of Health and Human Services, Administration for } \\
\text { Children and Families, Administration on Children, Youth and Families, } \\
\text { Children's Bureau (1999-2009a) Child Maltreatment. } \\
\text { Available at: } \\
\text { http://www.acf.hhs.gov/programs/cb/stats_research/index.htm\#afcars } \\
\text { U.S. Department of Health and Human Services, Administration for } \\
\text { Children and Families, Administration on Children, Youth and Families, } \\
\text { Children's Bureau (1999-2009b) Adoption and Foster Care Analysis and } \\
\text { Reporting System (AFCARS) annual data } \\
\text { Available } \\
\text { at:http://www.acf.hhs.gov/programs/cb/stats_research/index.htm\#afcars }\end{array}$ \\
\hline
\end{tabular}




\section{Challenges and limitations of using administrative child welfare data}

There is considerable potential to make use of aggregate administrative datasets to explore trends and variations in policy and practice and to assist in learning. However, it is also necessary to acknowledge some potential limitations of these as tools to aid understanding of trends in maltreatment. Firstly, they do not assist in determining the prevalence of abuse and neglect as they only supply data on children who come to the attention of children's social care; these children and young people reflect the tip of the iceberg as harm may go unrecognised or unreported (Gilbert et al., 2009a; Davies and Ward, 2012). Secondly, differences in definitions of maltreatment, thresholds for action, child protection processes and recording conventions mean that data from different countries or jurisdictions may not be comparable (Bromfield and Higgins, 2004; ChildOnEurope, 2009; ISPCAN, 2010; Munro et al., 2011a; Munro, Brown and Manful, 2011). Bromfield and Higgins (2004) identify that the likelihood of compromised reliability and validity increases when data from several jurisdictions are amalgamated (p. 28). Thirdly, rates of maltreatment may be inflated when children in need or 'at risk' of abuse but who have not necessarily suffered significant harm are included in the datasets (Bromfield and Higgins, 2004; Munro, Brown and Manful, 2011). Fourthly, data may be missing or incomplete and databases may not be designed appropriately for follow-up studies (Simpson et al., 2000). Findings from this study also highlight differences in the data that countries collect and what they routinely publish and thus what is readily available for analysis without having to negotiate with gatekeepers to access data that have been collected but are not in the public domain.

Finally, use of a combination of administrative data and other data sources can distort comparisons and result in wide variations in the figures cited at key points in the child protection process for different countries. For example, the OECD report Doing Better for Families (OECD, 2011) suggest that 'annual reported child maltreatment to child protection agencies range from $1.5 \%$ in England, $3.3 \%$ in Australia to $4.8 \%$ in the United States' (OECD, 2011, p.427). The figures cited are taken from Gilbert and colleagues' (2009b) article on the burden and consequences of child maltreatment in high-income countries (p.68-81). The 1.5\% referral figure quoted for England excludes neglect and intimate-partner violence and is taken from Cleaver et al's (2004) research study on assessing children's needs and circumstances. The rate of $3.3 \%$ cited for Australia is based on administrative data rate of referrals for Victoria (AlHW, 2004) and the U.S. figure that is cited is from a National Incidence Study cited by Euser et al. (2010). This reinforces the importance of examining variations in data sources and considering the implications these have before drawing comparisons. 


\section{Child welfare: a changing landscape}

This Chapter begins with an exploration of the similarities and differences in the child welfare systems in operation in England, Australia, Norway and the U.S. and then goes on to provide a broad overview of developments in policy and practice in each of these countries over the last decade. This serves as a foundation to assist in understanding the social, political and economic context in which child welfare operates and the rationale behind key reforms aimed at protecting and promoting the welfare of children.

\section{Similarities and differences in child welfare systems and their implications}

Typologies of child welfare systems assist in understanding similarities and differences in the number of children who come to the attention of statutory children's social care services and subsequent service responses to meet their needs. Comparisons of social policy and practice in the 1990s revealed two key approaches (Gilbert, 1997; Gilbert et al., 2009a; Hetherington et al., 1997). Anglo-American countries including England, the U.S. and Canada were classified as adopting a child protection approach whereas Nordic and Continental European countries were classified as adopting a family service approach. Countries adopting a child protection orientation tend to view child protection as distinct from a wider continuum of services for children with lower levels of need, to delay intervention and adopt a more legalistic approach. In contrast the family service approach is essentially needs based; child protection investigations are seen as part of a continuum of services for children in need and their families, and agencies respond to allegations of maltreatment alongside referrals for family support services for children who may be in need but not likely to suffer significant harm. This model lends itself to an ecological approach to assessment, and provides a rationale for early interventions, and the strengthening of primary and secondary level services (Gilbert, 1997; Gilbert et al., 2009a; Hetherington, 2006). However, these models do not neatly categorise all aspects of child welfare systems and perspectives differ on some countries classifications (Freymond and Cameron, 2006). For example, England has been classified as operating a child protection approach by some, while others suggest it operates a family service model (Hetherington, 2006; Gilbert et al., 2009a) ${ }^{15}$. More broadly, questions have been raised as to whether these orientations apply to child welfare systems beyond the 1990s; policy and practice developments have served to challenge traditional ideologies and orientations (Gilbert, Parton and Skivenes, 2011). Gilbert

\footnotetext{
${ }^{15}$ Since the late 1990s there have been efforts to refocus on holistic family support rather than child protection responses to children and their families and on safeguarding and promoting the welfare of children; the pendulum has shifted back towards child protection since media coverage of the death of Peter Connelly in 2008 (Department of Health, 1999; Department of Health 2000; France et al., 2011; Holmes, Munro and Soper,2010; Laming, 2009; Parton and Berridge, 2011;Platt, 2005).
} 
and colleagues (2011) suggest that as countries have sought to strike a new balance between child protection and family services that a new orientation has emerged which is child-focused and the object of concern is the child's overall wellbeing and development. Gilbert et al. (2011. p.255-6) outline their interpretation of variations between orientations (Table 2 below). They also argue that 'although some countries might emphasize one or more of the orientations more than another in their approach to child maltreatment, all countries contain some mix of these orientations'.

Table 2: Role of the state vis-a-vis child and family in orientations to child maltreatment: child focus, family service and child protection

\begin{tabular}{|l|l|l|l|}
\hline & Child Focus & Family Service & Child Protection \\
\hline $\begin{array}{l}\text { Driver for } \\
\text { intervention }\end{array}$ & $\begin{array}{l}\text { The individual child's needs in } \\
\text { a present and future } \\
\text { perspective; society's need } \\
\text { for healthy and contributory } \\
\text { citizens }\end{array}$ & $\begin{array}{l}\text { The family unit } \\
\text { needs assistance }\end{array}$ & $\begin{array}{l}\text { Parents being } \\
\text { neglectful and } \\
\text { abusive towards } \\
\text { children } \\
\text { (maltreatment) }\end{array}$ \\
\hline $\begin{array}{l}\text { Role of the } \\
\text { state }\end{array}$ & $\begin{array}{l}\text { Paternalistic/defamilialization- } \\
\text { state assumes parent role; } \\
\text { but seeks to refamilialize child } \\
\text { by foster home/kinship } \\
\text { care/adoption }\end{array}$ & $\begin{array}{l}\text { Parental support; the } \\
\text { state seeks to } \\
\text { strengthen family } \\
\text { relations }\end{array}$ & $\begin{array}{l}\text { Sanctioning; the } \\
\text { state functions as } \\
\text { 'watchdog' to } \\
\text { ensure child's safety }\end{array}$ \\
\hline $\begin{array}{l}\text { Problem } \\
\text { frame }\end{array}$ & $\begin{array}{l}\text { Child's development and } \\
\text { unequal outcomes for } \\
\text { children }\end{array}$ & $\begin{array}{l}\text { Social/psychological } \\
\text { (such as system, } \\
\text { poverty and racism) }\end{array}$ & Individual/moralistic \\
\hline $\begin{array}{l}\text { Aim of } \\
\text { intervention }\end{array}$ & $\begin{array}{l}\text { Promote wellbeing via social } \\
\text { investment and/or equal } \\
\text { opportunity }\end{array}$ & $\begin{array}{l}\text { Prevention/social } \\
\text { bonding }\end{array}$ & $\begin{array}{l}\text { Protection/harm } \\
\text { reduction }\end{array}$ \\
\hline $\begin{array}{l}\text { State-parent } \\
\text { relationship }\end{array}$ & Substitutive/partnership & Partnership & Adversarial \\
\hline $\begin{array}{l}\text { Balance of } \\
\text { rights }\end{array}$ & $\begin{array}{l}\text { Children's rights/parents' } \\
\text { responsibility }\end{array}$ & $\begin{array}{l}\text { Parents' rights to } \\
\text { family life mediated } \\
\text { by professional } \\
\text { social workers }\end{array}$ & $\begin{array}{l}\text { Children's/parents' } \\
\text { rights enforced } \\
\text { through legal means }\end{array}$ \\
\hline
\end{tabular}

Source: Gilbert, Parton and Skivenes, 2011b, Table 12.2, p. 255

\section{Legal and policy frameworks governing child welfare}

\section{Australia}

In Australia, child protection is a state and territory government responsibility, and there are significant differences in how each deals with and reports child protection issues (AIHW, 2011; Bromfield and Holzer, 2008). Each territory has legislation that defines whether children are in 'need of care and protection' and the threshold for placement away from home (see AlHW, Appendix 4 for full details). Although there are variations in definitions, Bromfield and Holzer's (2008) exploration of similarities and differences in systems and services identified a series of common guiding principles across jurisdictions. These include: 
- The best interests principle;

- Use of early intervention services with the goal of preventing entry/re-entry in the statutory system (although delivery of such services varies);

- Young people's participation in the decision-making process;

- Aboriginal Child Placement Principles (placement principles for Aboriginal and Torres Strait Islander children).

Greater divergence was identified in respect of the principles governing permanence and placement stability as well as service responses to meet the needs of young people making the transition from care to adulthood (Bromfield and Holzer, 2008; Cashmore and Mendes, 2008).

Although there are variations between jurisdictions, Australia has traditionally been viewed as a 'child protection' system. However, since around 2002 territories have been embarking on reforms designed to build capacity and strengthen families with a view to preventing abuse and neglect (Bromfield and Holzer, 2008; Higgins and Katz, 2008). Although jurisdictions are at different stages of implementation reforms have been orientated towards developing early intervention services to reduce the escalation of problems within families and reducing the need for more intrusive intervention into family life. A number of areas have implemented cross-departmental strategies with an aim to assist families in a more holistic way, by coordinating service delivery and providing access to different types of child and family services (Bromfield and Holzer, 2008). Community engagement models have also developed with a view to promoting engagements and ensuring that responses are culturally appropriate (Lonne et al., 2008; O’Donnell et al., 2008; Scott, 2005). In 2009 these developments were endorsed in the first National Framework for Protecting Australia's Children 2009-2020 (Council of Australian Governments, 2009)) which provides an overarching conceptual framework for developments in policy and practice. This acknowledges that:

Australia needs to move from seeing 'protecting children' merely as a response to abuse and neglect to one of promoting the safety and wellbeing of children (p.7).

The framework recognised the importance of early prevention and intervention programmes in protecting Australia's children and also emphasises that protecting children is a shared responsibility, within families, and across communities, professions, services, and governments. 


\section{England}

The Children Act 1989 introduced the concept of significant harm as the threshold that justifies compulsory intervention in family life to safeguard or promote the welfare of a child who is suffering, or likely to suffer, significant harm. Under section 31(9) of the Children Act 1989, as amended by the Adoption and Children Act 2002:

- 'harm' means ill-treatment or the impairment of health or development, including for example impairment suffered from seeing or hearing the ill-treatment of another;

- 'development' means physical, intellectual, emotional, social or behavioural development;

- 'health' means physical or mental health; and

- 'ill-treatment' includes sexual abuse and forms of ill-treatment that are not physical.

Under section 31(10) of the Act:

Where the question of whether harm suffered by a child is significant turns on the child's health and development, his or her health and development shall be compared with that which could reasonably be expected of a similar child.

The underpinning principles of the Act are that:

- The welfare of the child is the paramount consideration;

- Wherever possible, children should be brought up and cared for within their own families;

- Authorities should work in partnership with parents;

- Orders under the Act should not be made unless it can be shown that this is better for the child than not making an order ('no order' principle);

- Delays in decision-making are detrimental and likely to prejudice the welfare of children.

In the mid-1990s a series of research studies provided an insight into how the Children Act 1989 and its underlying principles were being applied in practice. Child Protection:

Messages from Research revealed that the system was focused upon child protection at the expense of providing for the broader welfare needs of children and families (Department of Health, 1995). In response efforts were made to adopt a less adversarial approach and 'refocusing' upon supporting families and providing services for children under section 17 of the Children Act (services for 'children in need'). This can be understood as a direct attempt to shift away from a child protection response towards a more family service orientated 
approach (Parton and Berridge, 2011). Working Together to Safeguard Children (1999) reiterated that 'effective measures to safeguard children should not be seen in isolation from the wider range of support and services available to meet the needs of children' (Department of Health et al., 1999, 1.9). The Framework for Assessment of Children in Need and their Families (Department for Health, 2000) was also implemented to assist professionals in assessing children in need within their family and environment. These reforms also need to be understood with reference to wider developments. The New Labour government elected in 1997 implemented a series of wider reforms underpinned by a belief in the importance of investing in children to maximise their contribution to society and the economy as citizenworkers of the future (Williams 2004, see also Dobrowolsky 2002; Fawcett al., 2003; Lister $2003,2006)$. Early intervention and prevention were seen to be cost effective as a means of improving children's life chances and forestalling anti-social behaviour, crime and unemployment. Although emphasis was placed upon investing in and safeguarding all children, specific groups were also targeted to receive additional support because they have been identified as being at high risk of experiencing adverse outcomes and social exclusion.

The Green Paper Every Child Matters was published alongside the formal response to the tragic death of Victoria Climbié, who although known to four different social services departments, two hospitals, two child protection teams and a family centre, suffered abuse and neglect and was killed by her great-aunt and her partner (Cm 5730, 2003; HM Government, 2003). The event accelerated reforms that were already underway (Davies and Ward, 2012). They reflected the ethos of early intervention and prevention as well as outlining universal ambitions for every child and young person (be healthy, stay safe, enjoy and achieve, make a positive contribution, achieve economic wellbeing). The Children Act 2004 was also introduced to provide the legal underpinning for the reforms and to support changes in the organisation and delivery of services, with emphasis placed upon interagency working and 'joined up' services. These reforms were subject to review in 2008 in the wake of the death of Peter Connelly, who died at the hands of his carers even though he was the subject of a child protection plan and seen by over 60 health and social care professionals (Lord Laming, 2009). At this juncture the pendulum shifted away from the broader concept of safeguarding and promoting the welfare of children which had become central to policy and back towards child protection (France et al, 2010; HM Government 2009). This change in emphasis was also fuelled by media and public hostility towards children's social care professionals as well as anxiety amongst social workers about the consequences of failing to protect children and the risk of media and public vilification (Munro, 2011; Holmes, Munro and Soper, 2010; Parton and Berridge, 2011). Matters were also exacerbated by the global economic crisis and associated pressures on families. 
The social, political and economic landscape altered again in 2010 when the Coalition government came to power. Professor Eileen Munro was commissioned to undertake another review of child protection on the grounds that:

the reforms led by the previous administration were well-intentioned...But the child protection system in our country is not working as well as it should (Tim Loughton, MP, Parliamentary Undersecretary of State, 2011).

The Munro review of child protection concluded that the child protection system had been shaped by four key driving forces:

- the importance of the safety and welfare of children and young people and the understandable strong reaction when a child is killed or seriously harmed;

- a commonly held belief that the complexity and associated uncertainty of child protection work can be eradicated;

- a readiness, in high profile public inquiries into the death of a child, to focus on professional error without looking deeply enough into its causes; and

- the undue importance given to performance indicators and targets which provide only part of the picture of practice, and which have skewed attention to process over the quality and effectiveness of help given (Cm 8062, p. 6).

It was identified that these factors had:

come together to create a defensive system that puts so much emphasis on procedures and recording that insufficient attention is given to developing and supporting the expertise to work effectively with children, young people and families (Cm 8062, p. 6).

In response Munro recommended changes to reduce bureaucracy and establish a more child-centred system. However, it is too early to say whether these ambitions will be realised and whether they will serve to improve outcomes for children and families in England.

\section{Looked after children and adoption}

Since 1999 a range of legal and policy developments have been implemented with the aim of improving outcomes for looked after children. These include: the Quality Protects and Choice Protects initiatives; the Children (Leaving Care) Act 2000; the Adoption and Children Act 2002 and the Children and Young Persons Act 2008. The Coalition government have signalled that improving the lives of looked after children continues to be a key priority. They 
have also committed to ensure that the adoption system works more effectively and efficiently and delays in the decision making process are reduced $(\mathrm{Cm} 8273,2012)$.

\section{Norway}

In Norway maltreatment is understood to be 'treating a person cruelly or with violence; incest, sexual and physical abuse are criminal acts' (Kairys and Johnson, 2002, p.1; Skivenes, 2011). Care orders may be granted if the following threshold for intervention is crossed:

- there are serious deficiencies in the daily care received by the child, or serious deficiencies in terms of the personal contact and security needed by a child of his or her age and development;

- the parents fail to ensure that a child who is ill, disabled, or in special need of assistance received the treatment and training required;

- the child is maltreated or subjected to other serious abuses at home; or

- there is every probability that the child's health or development may be seriously harmed because the parents are incapable of taking adequate responsibility for the child.

An order may only be made pursuant to the first paragraph when required by the child's situation. Hence, such an order may not be made if satisfactory conditions can be created for the child by assistance measures pursuant to section $4.4^{16}$ or by measures pursuant to section 4.10 or 4.11 (Section 4.12, Child Welfare Act 1992, in Skivenes, 2011, p.161).

The principles of the legislation are:

- Measures should be in the best interests of the child;

- The biological principle; ideally children should be raised by their biological parents and within the family;

- The least intrusive form of intervention should be adopted;

- Promotion of stability and continuity.

The Child Welfare Act 1992 law has been described as marking a new era in child welfare; it 'tried to make the child welfare system more service oriented and to remove some of the stigma of being a service user by associating the child welfare system with the positive

${ }^{16}$ Services for children with special needs. 
connotations of the welfare state' (Skivenes, 2011, p.158) ${ }^{17}$. Emphasis was placed on lowering thresholds for intervention and promoting early intervention and prevention through the provision of support and promotion of equality of opportunities (Healy and Oltedal, 2010; Kojan, 2011; Tjelflaat, 2001). It was anticipated that this approach would secure children's rights and that offering services earlier would prevent the escalation of difficulties and thus reduce incidents of serious maltreatment and the demand or need for out of home placements.

In a summary of trends and changes in child welfare in Norway the following are highlighted:

- Implementation of family-orientated evidence based programmes, including multisystemic therapy (MST) aimed at young people and parent management training (PMT) with a focus on children with behaviour problems. However, it should be noted that these programmes reach a fairly small number of children and young people each year; on average 700-750 children benefit from MST each year and although the use of PMT is rising it reached just under 1000 in $2010^{18}$;

- A child-centred approach, including the incorporation of the UNCRC into Norwegian Human Rights legislation in 2003, giving an increased impetus to including children and young people in decisions concerning them. This ensures that children are viewed as individuals rather than citizen workers of the future (Archard and Skivenes, 2009; Lister 2006);

- Improved provision of services for young people making the transition from care to adulthood (services provided before a child reaches 18 can be maintained or substituted by other services until the young person reaches the age of 23 , amendment implemented in 1998) (Skivenes, 2011; Storo, 2008) ${ }^{19}$.

However, Skivenes (2011) also highlights that many of the services offered are 'compensatory', for example, the provision of day care; these do not directly address issues affecting parenting capacity or the interaction between children and their families. There are also wide variations in the quality of case work and services implemented by the Norwegian municipalities that have responsibility for administering child welfare services.

\footnotetext{
${ }^{17}$ The Norwegian welfare state tries to distribute services according to universal principles of human dignity and justice and seeks to guarantee citizens minimum standards of income, livelihood, housing accommodation, and education' (Eriksen and Loftager, 1996, p.2; Skivenes, 2011).

${ }^{18}$ The number of children receiving services is around 50,000 and many of these are of more limited scope, for example, home-based services, including economic subsidies, respite care, kindergarten (Backe-Hansen, personal communication).

${ }_{19}$ These provisions are mainly for 18 and 19 year olds and service rates decrease sharply for those aged 20+ (Backe-Hansen, personal communication).
} 


\section{The United States}

Relative to other post-industrialised democracies the U.S. has a relatively residual and decentralised welfare state (Courtney, 2008). Federal law shapes minimum standards for child welfare in the U.S. and each state has considerable autonomy in how they operate (Berrick, 2011; Courtney, 2008). At the Federal level it is acknowledged that child maltreatment includes, at a minimum:

- any recent act or failure to act on the part of a parent or caretaker which results in death, serious physical or emotional harm, sexual abuse or exploitation; or

- an act or failure to act which presents an imminent risk or serious harm (Child Abuse Prevention and Treatment Act, 1974).

All states are required to make 'reasonable efforts' to prevent children's removal from their parents and if children are removed services must be offered to families to support reunification and children must be placed in the 'least restrictive' setting possible (U.S. Department of Health and Human Services, 2009). Federal law acknowledges the importance of securing permanence for children; ideally with birth parents but if they are unable to provide a safe home then measures should be taken to secure alternative permanent arrangements with relatives, via adoption, or legal guardianship. The Adoption and Safe Families Act 1997 (ASFA-P.L. 105-89) sought to expedite adoption by placing timescales on parents to address the matters placing their child at risk (12 months with a possible six month extension). Policy developments continue to promote the use of adoption. Under the Fostering Connections to Success and Increasing Adoption Act 2008 (P.L. 110351) states were given financial incentives for each adopted child over and above the state's base number of adoptions from the year 2002 (Fostering Connections to Success, 2008). Federal support has also been given to the use of legal guardianship with kin (Berrick, 2011). However, 'child maltreatment reporting laws, system response activities, social worker practice, and standards for care all vary substantially depending on local law and custom' (Berrick, 2011, p.17). In this context providing a national picture of child welfare changes and developments is problematic. However, there are some general trends and issues that commentators identify as influencing the general direction of travel in the U.S.

The 1990s saw a rapid expansion in the use of out of home care which has been attributed, in part at least, to a rise in the number of very young children coming to the attention of child welfare agencies because of parental crack cocaine use. This placed increasing demand on fostering services, reunification rates dropped and adoption stagnated (Berrick et al., 1998). In addition there was a rise in litigation against child welfare authorities (Kosanovich and 
Joseph, 2005). In this context states and local jurisdictions have increasingly sought to implement reform efforts which aim to promote early intervention and prevention through the development of family-centred practice and greater use of community partnerships (Berrick, 2011; Schene, 2006). Schene (2006) suggests that this has been influenced by growing recognition of the limitations of existing systems, heightened awareness and willingness on the part of the community to play a greater role in protecting children and increased focus on outcomes and accountability that are challenging to realise without utilisation of a range of services and supports that partnerships assist in delivering (p.88-9).

Overall, these overviews illustrate how countries' responses to child maltreatment are evolving. They illustrate some common features but it is also important to acknowledge that there are still considerable variations within and between countries. Differences in definitions of abuse and neglect, which will influence referrals and notifications to children's social care services are explored below. 


\section{Definitions of abuse and neglect and percentage of children affected by different types of maltreatment}

There are cross-national variations in the operational definitions of physical, sexual, emotional abuse and neglect that countries (states or territories) employ, reflecting different legislative frameworks and social and cultural influences (Gilbert et al., 2009; Munro et al., 2011a; OECD, 2001; Schwartz-Kenney et al., 2001). Such variations will influence the recognition of abuse and the relative percentage of children classified as suffering from different types of maltreatment. In a review of similarities and differences Munro and colleagues (2011) concluded that definitions of physical and sexual abuse were fairly consistent but there was less agreement concerning what constitutes emotional abuse and neglect, in part due to the overlap between these two phenomena and their complex and multifaceted nature (Ward et al., 2004; Iwaniec, 1995; Davies and Ward, 2012). Appendix 1 provides further detail.

The figures below show the relative distributions of different categories of abuse in England $^{20}$, Australia, the U.S. and Norway. To facilitate comparisons some data items were re-coded: the U.S. medical neglect category was incorporated with other types of neglect. Norway collects and publishes detailed information on children's needs under 18 categories. For this report the following: disabilities, drug use, psychological problems and behavioural difficulties were reclassified under 'child's behavioural issues' and issues affecting parenting capacity: parent's somatic ${ }^{21}$ illness, parents' mental suffering, parents' drug excess, parents' inability of care and domestic conditions were reclassified as 'issues affecting parenting capacity'.

\footnotetext{
${ }^{20}$ In England prior to 2002 the main categories of abuse incorporated mixed categories of abuse under each category which was cited. From 2002 onwards mixed categories of abuse were published under a separate category, which is included within "other" in the charts below.

${ }^{21}$ Psychosocial stress.
} 

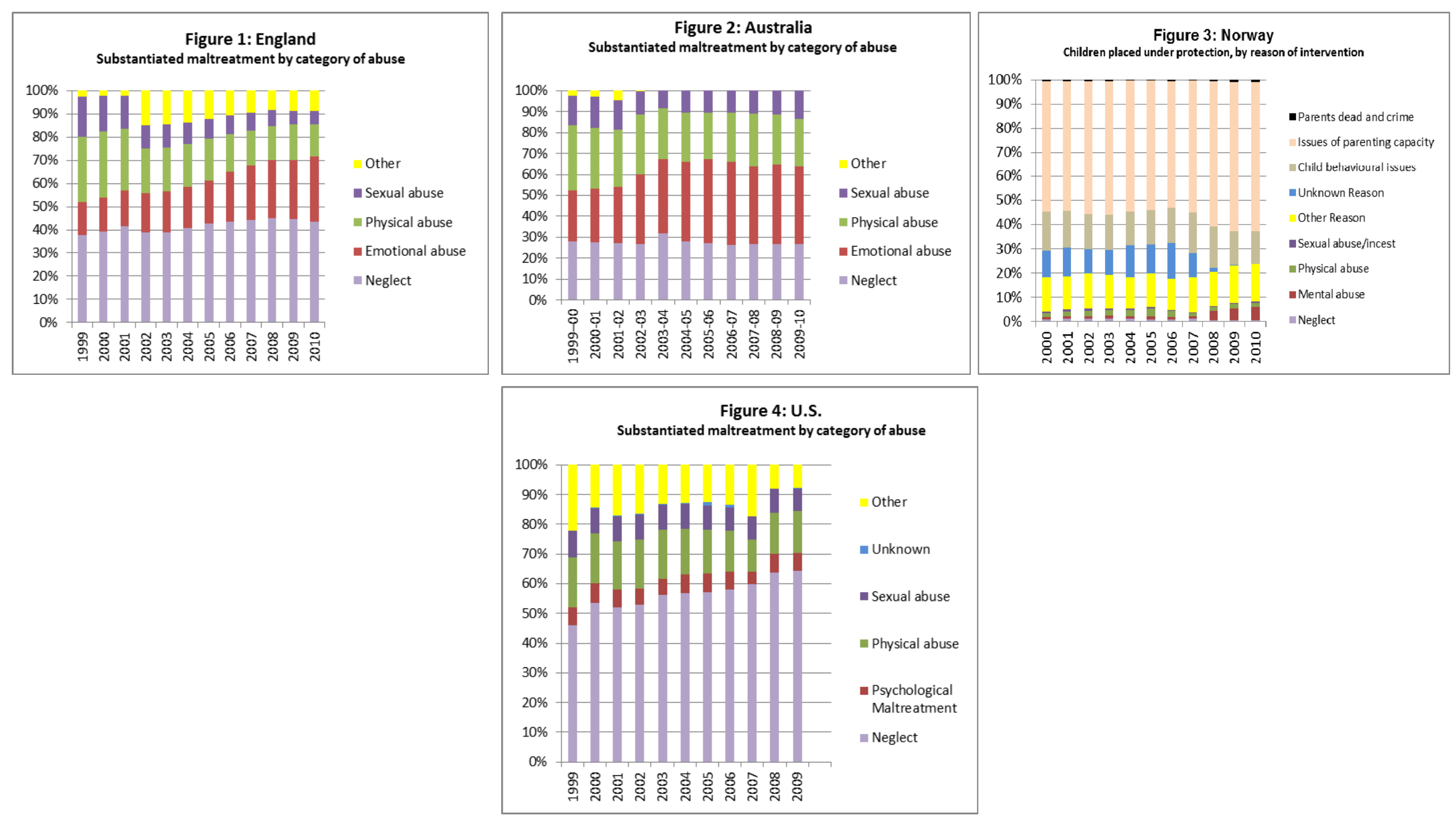
The figures above show that there is a downward trend in the percentage of cases being categorised under physical abuse in each county; the percentage of sexual abuse substantiations are also on the decline everywhere except in Australia. A number of factors may contribute to understanding this, including: changes in public awareness and attitudes, prohibition of corporal punishment in some jurisdictions, more aggressive prosecution and incarceration policies and dissemination of new treatment options (Finkelhor, 2011; Parton and Berridge, 2011). The data also reveal that in England, Australia, and the U.S. the majority of maltreated children ${ }^{22}$ are now classified under the category of neglect (England and the U.S.) or emotional abuse (Australia) ${ }^{23}$. The trend in reported maltreatment types differed in Norway due to the different categorisation it employs; the proportion of cases reported as neglect is low yet the majority of cases reported are due to issues affecting parenting capacity, including mental ill health, drug misuse, inability to care and domestic conditions which may contribute to neglectful parenting.

As outlined above, there is greatest definitional ambiguity at an international level concerning neglect and emotional abuse. These two types of maltreatment accounted for between $49 \%$ (Australia) and $54 \%{ }^{24}$ (England) of identified cases of maltreatment in 1999; and 64\% (Australia) and $72 \%$ (England) in $2010^{25}$. It is also noteworthy that in the last decade there has been an increase in the percentage of children categorised under emotional abuse in England, Australia and Norway. This appears to reflect increasing recognition of the detrimental impact of this form of abuse on children's wellbeing and development and corresponding efforts to promote improved recognition and responses through changes in reporting triggers or legislation (Adoption and Children Act 2002; Bromfield and Holzer, 2008). For example, in England amendments were introduced under the Adoption and Children Act 2002 to extend the definition of significant harm (section 31, Children Act 1989) to include 'impairment suffered from seeing or hearing the ill-treatment of another'. Since then the proportion of children who became the subject of a child protection plan due to emotional abuse has risen by approximately $80 \%$ (from 6,000 in 2006 to 10,800 in 2010). More recently, measures have been taken in Norway to improve recognition of this type of abuse. In 2009 the mandatory reporting provision of the Criminal Code was changed to require citizens to notify the police if they suspect domestic violence (Skivenes, 2011).

\footnotetext{
${ }^{22}$ Substantiated cases in England, Australia and the U.S. and children placed under protection in Norway.

${ }^{23}$ There are variations between territories; in Western Australia and the Northern Territory neglect was the most commonly substantiated maltreatment type in 2009-10 (AlHW, 2011; Lamont, 2011).

${ }^{24}$ In England in 1999 if mixed categories of abuse applied then each category of abuse was recorded. Therefore, the percentage cited is the percentage of recorded categories of abuse rather than the percentage of cases.

${ }^{25}$ Percentages have been rounded.
} 
Again, this demonstrates how influential changing organisational and professional responses to different types of abuse can be. The contribution of such changes to the number of children and families supported by children's social care services are explored further in the remainder of the report.

\section{Responding to abuse and neglect}

\section{Referrals, assessments and substantiation of abuse and neglect}

Interpreting the meaning of changes in numbers and rates of referrals, assessments and substantiation of maltreatment over time is complex: a wide range of factors may play a part. Although these may influence the volume of cases coming to the attention of children's social care services and subsequent service responses to protect and promote the welfare of children, it is not always immediately apparent how they interact, or whether the changes are beneficial. For example, increasing referrals may be perceived to be positive, reflecting improved recognition of abuse or neglect; or negative, if cases coming to the attention of children's social care services are not deemed to require statutory investigation. This section explores cross-national variations in the number and rates of referrals and assessments and how often abuse is substantiated. It goes on to explore similarities and differences in the recognition of, and responses to, abuse and neglect over time within and between countries.

\section{Referrals}

Referral data may be collected on the total number of referrals entering the child welfare system (which may include multiple referrals for a given child in a given year) and/or the number of children who are the subject of a referra| ${ }^{26}$. Australia and the U.S. collect child-

\footnotetext{
${ }^{26}$ Definitions and terminology vary. In Australia the term referral is associated with diverting cases away from the statutory system. Notification is the term used to describe cases entering the child protection system, although definitions vary across jurisdictions. For example, in some jurisdictions notifications are 'caller-defined'; that is, all contacts to the authorised department regarding concerns for children (and child protection reports) are considered to be a notification. In other jurisdictions notifications are 'agency-defined'. In these cases the initial report is subject to an assessment and considered a notification only when the information received suggests that a child needs care or protection. In England a referral is defined as: 'a request for services to be provided by the social services department.' This is in respect of a case where the child is not previously known to the council, or where the case was previously open but is now closed. Norway: In 1997 changes were made to the child welfare statistics form and the number of reports to child welfare authorities (referral cases) was not included. U.S: Referral is defined as an allegation of abuse and neglect received by a Child Protection Services agency.
} 
level data on the number of children who are the subject of a referral in a given year. In 2009-10 England started collecting child-level referral data. 
Figure 5 and Table 3 below utilise data on the total number of cases referred to children's social care services in a given year.

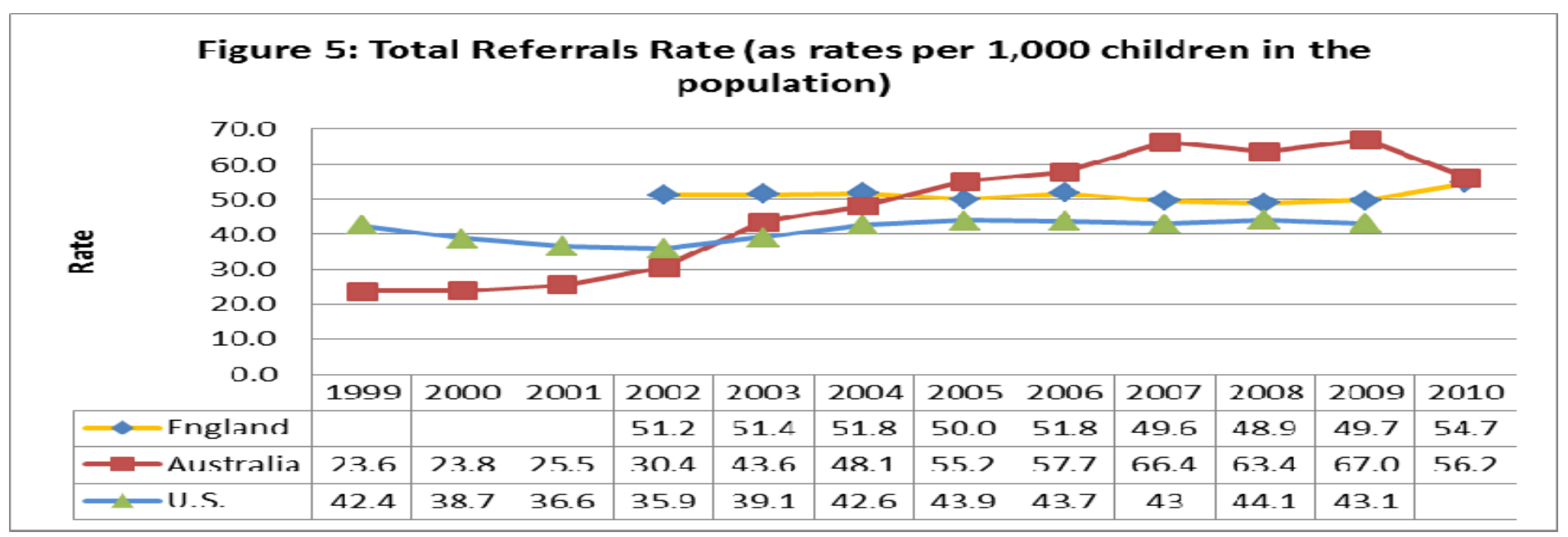

Table 3: Total number of cases referred to children's social care services in a given year

\begin{tabular}{|c|c|c|c|c|c|c|c|c|c|c|c|c|}
\hline $\begin{array}{l}\text { Referrals } \\
\text { received }\end{array}$ & 1999 & 2000 & 2001 & 2002 & 2003 & 2004 & 2005 & 2006 & 2007 & 2008 & 2009 & 2010 \\
\hline England* & & & & 569,400 & 570,200 & 572,700 & 552,000 & 569,300 & 545,000 & 538,500 & 547,000 & 603,700 \\
\hline Australia** & 103,302 & 107,134 & 115,471 & 137,938 & 198,355 & 219,384 & 252,831 & 266,745 & 309,448 & 317,526 & 339,454 & 286,437 \\
\hline U.S. & $2,975,797$ & $2,795,220$ & $2,673,000$ & $1,701,780$ & $1,390,330$ & $2,043,523$ & $2,176,425$ & $2,271,160$ & $2,085,443$ & $2,356,724$ & $2,569,547$ & \\
\hline
\end{tabular}

* The total figures for England in 2010 include estimates for missing data and are rounded to the nearest 100

**Data in 2004 excludes New South Wales because a new data system was implemented 


\section{Rates of referral}

As figure 5 above shows, England has the highest but also most consistently stable referral rate of the three countries for which data are presented, at around 50 per 1,000 children. In the U.S rates have ranged from a low of 35.9 in 2002 to a high of 44.1 in 2008; since 2004 rates have been fairly constant. In contrast, Australia's referral rate had increased significantly over the last ten years from 23.6 per 1,000 in 1999 to 67 in 2009 and declining to 56.2 in 2010 . This has been influenced by changes in policies and practices in state child protection systems, including mandatory reporting, broadening definitions of child abuse, increased reporting by professionals and increased community awareness concerning child maltreatment (AlHW, 2010).

In interpreting the data it is important to note that in England referrals include requests for services thus inflating figures relative to the U.S. where referrals are concerned with allegations of maltreatment. Mandatory reporting requirements also need to be taken into consideration. Research suggests that mandatory reporting requirements increase the volume of referrals into child welfare systems (even though these may not meet the threshold for further investigation) (Harries and Clare, 2002; Lonne et al., 2008; Mathews and Kenny, 2008). Australia, the U.S. and Norway all have mandatory reporting requirements, although there are variations in the threshold for referral and in who is required to report concerns. Although there is not a mandatory reporting requirement in England in addition to the statutory guidance Working Together, central government issued detailed practice guidance outlining 'What to do if you're worried a child is being abused?' to assist professionals to safeguard and promote the welfare of children. It is unclear what impact this had on referrals (Department of Health, 2003; HM Government, 2006).

Data on all referrals received by children's social care are not collected in Norway. However, data on referrals investigated reveals that between 1994 and 2008 there was a year on year increase in referrals investigated per 1,000 children; from 13.2 in 1994 to 25.2 in 2008. This has been attributed to implementation of the Child Welfare Act 1992 which encouraged lower thresholds and earlier intervention and use of in-home services with the aim of reducing the number of children in out of home placements (Skivenes, 2011). It is important to note that, consistent with the Nordic family services child welfare orientation that investigations are not limited to concerns regarding child protection. Indeed over half of cases open to investigation are triggered by 'conditions in the home' which tends to imply relatively minor problems (ibid). This also reflects variations in the thresholds for assessment and intervention in different countries. 


\section{Number of referrals}

In general, data on numbers of referrals show an upward trend in each country between the late 1990s and 2010. England saw around a 10\% increase in the number of referrals received between 2009 and 2010. An additional 56,700 referrals were received in the year ending 31 March 2010 compared to the year before. This has been attributed to the economic downturn, heightened anxiety in the system due to the death of Peter Connelly and associated media coverage. In 2009-10 there was also a move from aggregate to childlevel data collection which may have affected the data (Association of the Directors of Children's Services, 2010; Brookes, 2010; Department for Education, 2010; Holmes, Munro and Soper, 2010). Lord Laming's review of child protection recommended (among other things) that an initial assessment should be undertaken on all referrals from professionals and that all police, probation, adult mental health and adult drug and alcohol services should automatically refer cases where domestic violence or drug or alcohol abuse may put a child at risk of abuse or neglect (Lord Laming, 2009, Recommendations 19(1) and 20). Local authorities reported that full implementation of these proposals would have unintended and detrimental consequences and research highlighted the cost and capacity implications of initiating these changes (Holmes, Munro and Soper, 2010). The Government subsequently announced that social work discretion concerning case referral should remain (HM Government 2009; HM Government 2010).

Between 1999 and 2009 notifications in Australia more than tripled from 103,302 to 339,454. Child welfare statistics and enquiries into child protection assisted in raising awareness that the Australian child welfare system was overburdened and that considerable resources were being invested in referral and assessment rather than support services and interventions (Bromfield and Katz, personal communication; Council of Australian Governments, 2009; Holzer and Bromfield, 2008). In recent years policy initiatives have been implemented which aimed to re-focus the system on prevention and early intervention. These have contributed to the sharp decline in notifications (Australian Research Alliance for Children and Youth, 2008; Wood inquiry, 2008). The number of notifications received in 2010 fell by 53,017 cases (15.6 percent) from that of the previous year. For example, in New South Wales amendment of the Children and Young Persons (Care and Protection) Act 1998 raised the threshold for reporting concerns (from 'risk of harm' to 'risk of significant harm') and this contributed to a $27 \%$ decrease in reports of suspected abuse and neglect in 2009-10 (AIHW, 2011). 


\section{Referrals that do not progress to further assessment}

Not all referrals coming to the attention of children's social care services are deemed to require further action. Data from England, Australia and the U.S. are presented below. It is noteworthy that irrespective of the fluctuations in the number of children referred to child welfare services, the percentage of referrals that were 'screened' out of the U.S. child welfare system remained fairly consistent at around 40\%. In Australia there have been fluctuations in the percentage of referrals perceived not to require further action. In the period between 2002 and 2004 more than 55\% of referrals resulted in no further action. This could indicate that practitioners were referring inappropriate cases and/or that high thresholds for the receipt of services were in operation.

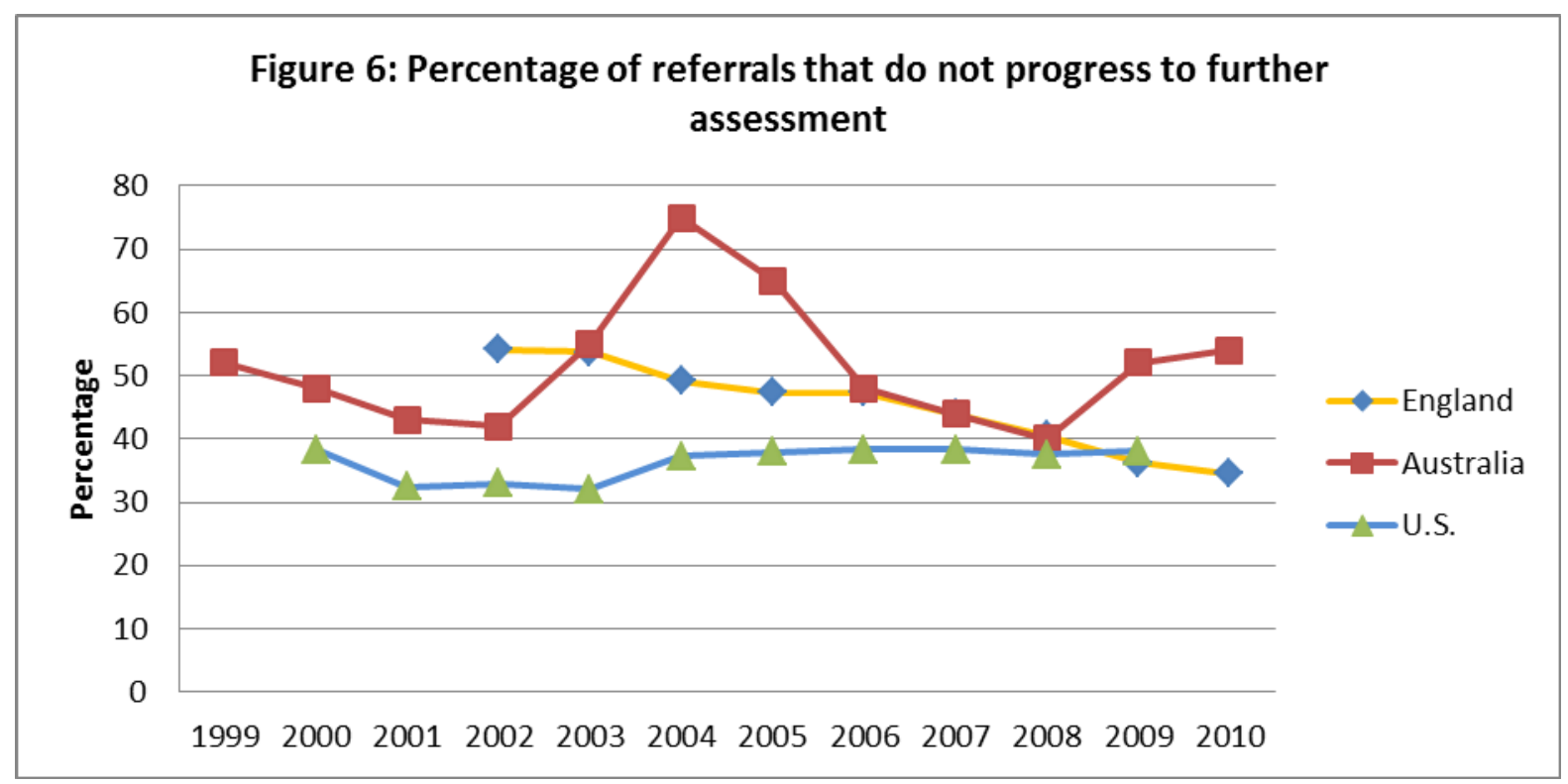

In England between 2002 and 2010 there was a steady decline in the percentage of referrals that resulted in no further action, from 54\% in 2002 to $35 \%$ in 2010 . This could reflect improvements in recognition and responses to safeguarding concerns amongst professionals resulting in more appropriate referrals; or that social workers have progressed more cases to initial assessment because of anxiety within the system. In practice it is also apparent that although local authorities are all governed by the same legal framework and statutory guidance there are wide variations in the decisions taken about case progression and these variations cannot be explained simply by virtue of variations in levels of need (Department for Children, Schools and Families, 2009; Munro, Soper and Holmes, 2010). 


\section{Assessments and investigations}

Difficulties are encountered drawing meaningful comparisons between data on assessments due to differences in the processes undertaken and thresholds for instigating them. In England and Norway actual or likely significant harm is not a prerequisite for undertaking an assessment of need (section 4-4, Child Welfare Act 1992; HM Government, 2010; Skivenes, 2011), while on the whole, investigations in the U.S and Australia are orientated towards determining whether maltreatment has occurred, thus influencing the volume of cases progressing through the child welfare system. Notwithstanding these issues it is also clear that even when practitioners are operating within the same legal framework and following the same statutory guidelines there will be variations in who they determine requires an assessment of need or an investigation to determine whether a child is at risk of maltreatment.

Figure 7, below shows the rate of assessments or investigations per 1,000 children in the population in each country. England has a multi-tier assessment process and therefore data are presented on each type of assessment.

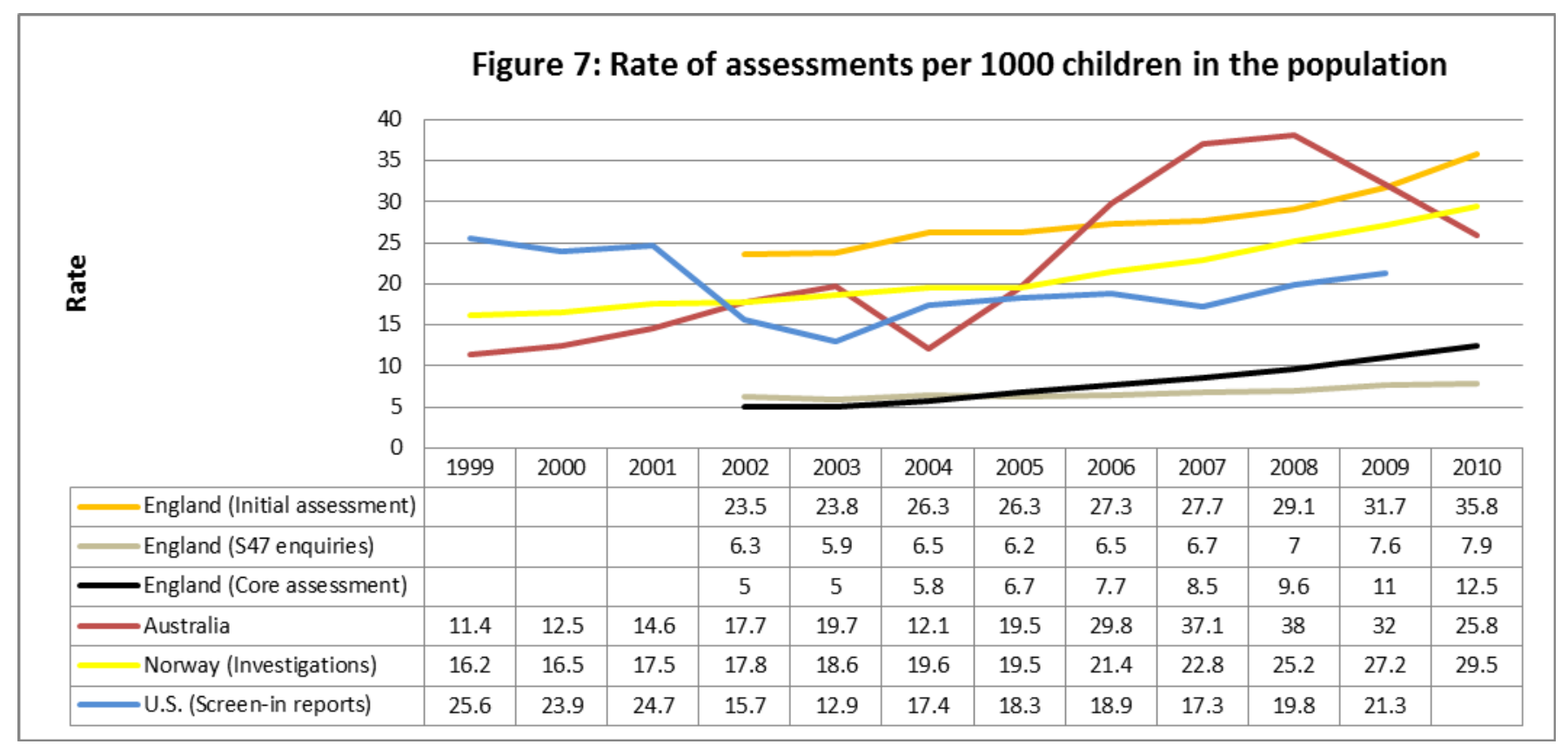

A complex picture emerges concerning changes in assessment rates. There are wide variations in the rate of assessments undertaken which means drawing valid comparisons between countries is problematic. In the U.S. and Australia there are intra-country variations concerning the conditions under which assessments should be undertaken. Even when practitioners are operating within the same legal framework and following the same statutory guidelines there will be variations in decisions concerning case progression. This relates not 
only to socio-demographic factors and levels of deprivation but also operational issues, including the culture within authorities and teams and resource and capacity issues (Munro et al., 2011a; Holmes, Munro and Soper, 2010). Overall the rate of assessment appears to have been on the rise in every country since 1999. In Australia, however, proactive efforts have been made to try and respond to difficulties encountered as a result of the $18.9 \%$ annual increase in the rate of change in the number of assessments undertaken during the period 2003-7. Legal and policy changes including, for example, implementation of the Care and Protection of Children Act 2007 (Northern Territory) and Children, Young Persons and their Families Amendment Act 2009 (Tasmania) and associated modifications in child welfare practices are likely to have influenced the declining rate of assessments since 2007 (37.1 per $1,000-25.8$ per 1,000 in 2010).

There are similarities in expectations of when initial assessments in England and investigations in Norway should be undertaken. In both countries assessments are undertaken if it is considered that the child may be a child in need (which includes children with special needs or disabilities) and requires services (section 17, Children Act 1989; section 4.4, Child Welfare Act 1992). Data reveal that the rate of assessment in both countries has been on the increase but overall England has the highest rate, which stood at 35.9 per 1,000 in 2010 compared to 29.5 per 1,000 in Norway. However, the English data also facilitate exploration of the number and rate per 1,000 of children deemed to require an in-depth core assessment. These may be undertaken for children in need ${ }^{27}$ (section 17 , Children Act 1989) (and where there are no substantiated concerns that the child may be suffering, or is likely to suffer, significant harm) if further information is required to understand the child's needs and circumstances and the capacity of his or her parents to respond appropriately to their needs within the wider family and community context. Core assessments are also the means by which section 47 (child protection) enquiries are carried out (HM Government, 2010). Between 2002 and 2009 the published rate of core assessments per 1,000 children rose from 5 to 11 . The published rate of section 47 (child protection) enquiries also increased from 6.3 to 7.6 in the same period. In the year ending $31^{\text {st }}$ March 2010 social workers initiated 3,600 more section 47 enquiries and 17,000 more core assessments than in the preceding year.

\footnotetext{
${ }^{27}$ Under section 17 of the Children Act 1989, a child is a child in need if: $\mathrm{He} / \mathrm{she}$ is unlikely to achieve or maintain, or have the opportunity of achieving or maintaining, a reasonable standard of health or development without the provision for him/her of services by a local authority;

His/her health or development is likely to be significantly impaired, or further impaired, without the provision for him/her of such services; or

$\mathrm{He} / \mathrm{she}$ is a disabled child.
} 


\section{Substantiation of abuse}

In Australia and the U.S. specific data are collected on whether alleged abuse is substantiated post assessment ${ }^{28}$. In England, children who are the subject of a child protection plan are deemed to have passed the threshold to be classified as 'substantiated cases' (agencies judge that a child may continue to suffer, or is likely to suffer significant harm). However, these thresholds do not map exactly. Katz (personal communication) identifies that if a child has suffered harm but it is judged that they are now safe from harm then they would not become the subject of a child protection plan in England but would be recognised as a case of substantiated abuse in Australia. In Norway there is not a unified approach to substantiating allegations of maltreatment; child protection is one of the several reasons for state intervention in the lives of children (Skivenes, 2011). Kojan (2011) suggests that many children who become clients of the child welfare system in Norway are 'socio-economically marginalised rather than in need of protection'.

\footnotetext{
${ }^{28}$ Australia: A notification will be substantiated where it is concluded (after investigation) that the child has been, is being, or is likely to be, abused, neglected or otherwise harmed. Norway: Terminology not used. U.S.: An investigation disposition that concludes that the allegation of maltreatment or risk of maltreatment was supported or founded by State law or policy.
} 
Table 4: Number of cases of substantiated abuse per year*

\begin{tabular}{|l|r|r|r|r|r|r|r|r|r|r|r|r|}
\hline & $\mathbf{1 9 9 9}$ & $\mathbf{2 0 0 0}$ & $\mathbf{2 0 0 1}$ & $\mathbf{2 0 0 2}$ & $\mathbf{2 0 0 3}$ & $\mathbf{2 0 0 4}$ & $\mathbf{2 0 0 5}$ & $\mathbf{2 0 0 6}$ & $\mathbf{2 0 0 7}$ & $\mathbf{2 0 0 8}$ & $\mathbf{2 0 0 9}$ & $\mathbf{2 0 1 0}$ \\
\hline England & 33,450 & 32,950 & 29,900 & 27,700 & 30,200 & 31,000 & 30,700 & 31,500 & 33,300 & 34,000 & 37,900 & 44,300 \\
\hline Australia & 21,582 & 20,954 & 23,635 & 25,569 & 30,953 & 23,959 & 34,046 & 34,517 & 32,585 & 32,098 & 32,641 & 31,295 \\
\hline U.S. & 488,073 & 489,944 & 492,108 & 486,288 & 419,962 & 477,755 & 483,695 & 480,332 & 448,407 & 446,037 & 442,005 & \\
\hline
\end{tabular}

* In for the year 2003/04 Australia's data did not include New South Wales data due to the introduction of a new client information system.

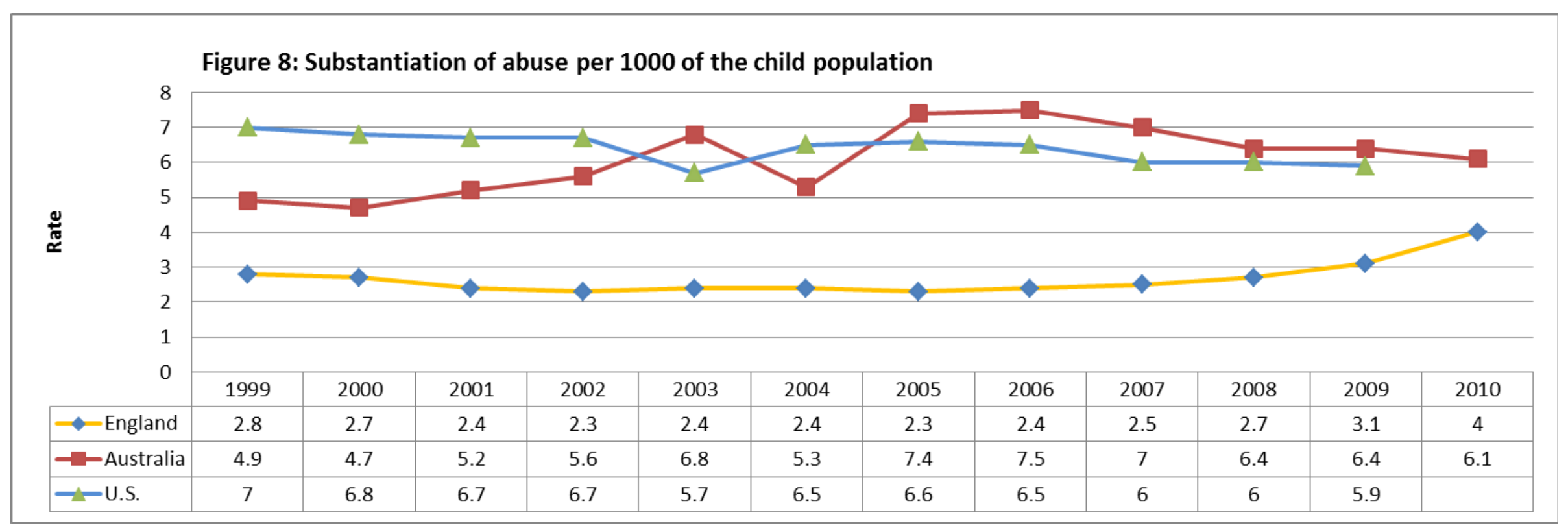


Table 4 above shows the number of children for whom abuse was substantiated in a given year and figure 8 shows changes in substantiation rates per 1,000 children. In the U.S. both the number of cases and rate of substantiation per 1,000 children have fallen since 1999 (488,073 and 7 per 1,000 in 1999 compared to 443,005 and 5.9 per 1,000 in 2009). The implementation of differential responses in 20 States may have contributed to this (Berrick, $2011)^{29}$. In Australia a more changeable picture emerges with fluctuations in numbers and rates of substantiation over the past ten years. Since 2005 the rate of substantiation has been falling and stood at 6.1 per 1,000 children in 2010 . One reason for this may be implementation of programmes such as Brighter Futures, a child protection prevention programme which is targeted at families most at risk of entering the child protection system (Wood, 2008).

In England the total number of children who were the subject of a child protection plan declined gradually from 1999 to $2005^{30}$ (annual rate change of $-1.2 \%$ ). Since then there has been a year on year increase in the number of children who have become the subject of a child protection plan. However, as Figure 8 above shows England has the lowest substantiation rate amongst the three countries. From 1999 to 2009 the rate was consistently below 3 per 1,000 children in the population at a time when a wide range of policy initiatives were implemented (see p. 21-24 for further detail) ${ }^{31}$. It appears that heightened anxiety within children's social care services following the death of Peter Connelly and negative media reporting concerning social work decision-making may have resulted in the marked rise in children who became the subject of a plan in the year ending 31 March 2010 (an additional 6,400 children started to be the subject of a plan compared to the preceding year; rate increase to 4 per 1,000$)^{32}$.

\section{Services and support}

Findings from a recent review of the availability and comparability of data on safeguarding children highlighted that in general limited data are collected on the provision of community based or in-home services for children and families and that there are significant challenges in undertaking meaningful comparisons of the data that are available due to variations in the

\footnotetext{
${ }^{29}$ Under this alternative system families reported for child maltreatment and identified as low to moderate risk are offered an assessment rather than an investigation and notions of substantiation are eliminated when possible and appropriate (Berrick, 2011).

${ }^{30}$ With the exception of 2003.

${ }^{31}$ One reason for the lower substantiation rate in England may be that in some circumstances concerns may be substantiated but it may be agreed between agencies that a plan for ensuring the child's future safety and welfare can be developed and implemented without a child protection plan (if for example, it is clear to the agencies involved that the child is not continuing to suffer, or be likely to suffer, significant harm (HM Government, 2010).

${ }^{32}$ Charts showing the changing trends of maltreatment types in relation to the rate of substantiation for each country are presented in Appendix 3.
} 
populations served and in the nature of the services provided (Munro et al., 2011a). This section explores what data are available and the strengths and limitations of this to assist in understanding patterns of service delivery and support for children coming to the attention of children's social care services in different countries.

The figures below show the relative proportions of children receiving different types of child welfare support in England, Norway and the U.S. ${ }^{33}$

In England the Children In Need ( $\mathrm{CiN}$ ) census provides child level data on all children who are referred to children's social care services. This has the potential to facilitate exploration of the volume of services provided, changes in patterns of service provision and the support children and young people receive as they move in and out of care (Holmes and McDermid, 2012). This statistical return reveals that in the year ending 31st March 2010 that there were 375,900 children in need (this includes looked after children, those supported in their families or independently and children who are the subject of a child protection plan); 44,300 were the subject of a child protection plan because it was assessed that they may continue to suffer, or be likely to suffer, significant harm) without the provision of services and the number of Looked After Children was 60,200 (the figure excludes those with placements with parents).

\footnotetext{
${ }^{33}$ Data on Australia have not been included as the AlHW only publish data on intensive family support services. Specifications are being developed to establish a minimum dataset in relation to treatment and support services (AlHW, 2011).
} 


\section{England}

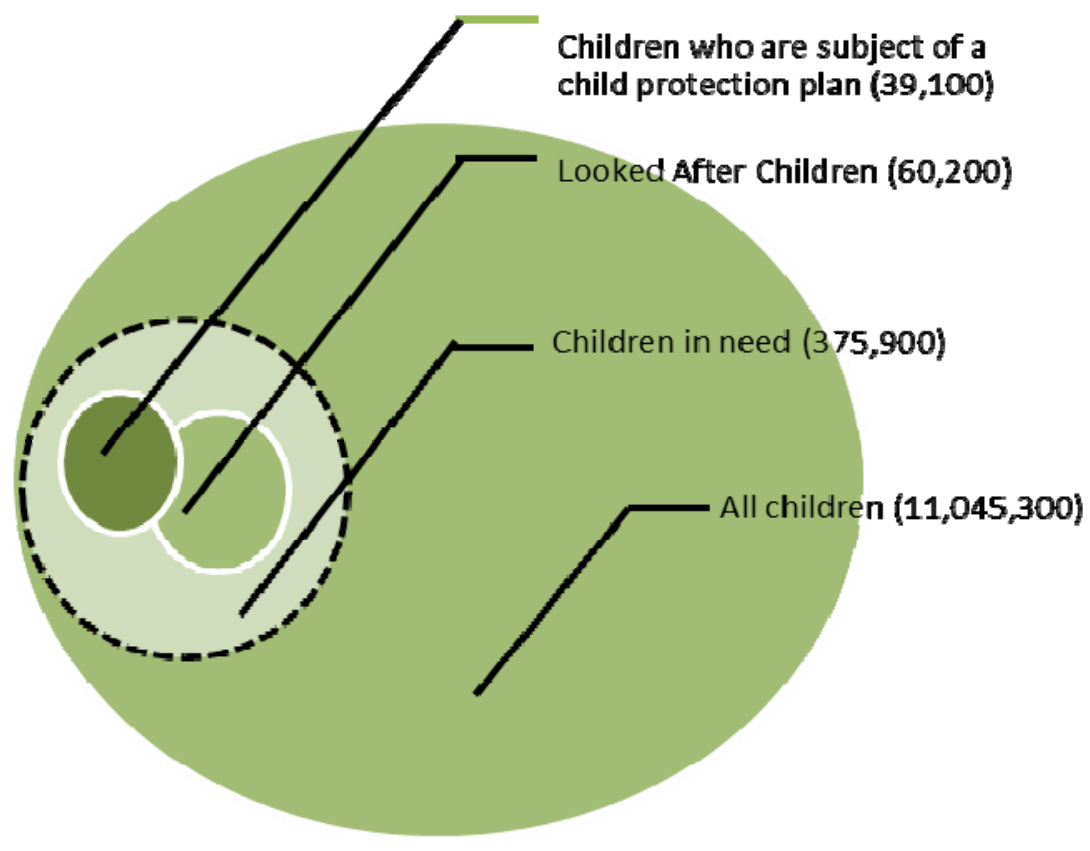

Figure 9: Representation of extent of children in need in England, 2010

All children: estimated number of $0-17^{34}$ years

- Children in need: a child in need is one who is unlikely to achieve or maintain, or have the opportunity of achieving or maintaining, a reasonable standard of health or development without the provision for him/her of services by a local authority.

This includes children looked after, those supported in their families and independently and children who are the subject of a child protection plan.

- Children who are subject of a child protection plan: equivalent of substantiated cases.

- Looked After Children: looked after children (care or accommodation by the local authority). Placements with parents have been excluded to facilitate comparisons.

In England further data are collected on the number and types of services children and their families receive. Details are provided in Tables 5 and 6 below.

${ }^{34}$ Estimate of all individuals below 18 years. 
However, it is important to acknowledge that obtaining robust and consistent data on additional services is problematic (Holmes and McDermid, 2012). CiN Census data are restricted to the collection of data on services provided or funded by local authority Children's Social Care Services so that activity from other providers, including health and education to promote the welfare of children are not accounted for. Irrespective of this restriction, many Local Authorities struggle to supply accurate data and others fail to provide the data required on services for the census. These and other challenges have resulted in the recommendation that collection of data on services provided be suspended for the next two years ${ }^{35}$. Research also demonstrates that seemingly similar services may offer different types of support. Recording of data on additional services has also been found to be variable and inconsistent (Holmes et al., 2010; Holmes, McDermid and Sempik, 2010; Ward et al., 2008; Gatehouse, Ward and Holmes, 2008). Similar challenges are encountered in the U.S. as the following section illustrates.

Table 5: Number of children by number of services, at 31 March 2010

\begin{tabular}{|l|r|r|}
\hline $\begin{array}{l}\text { Number of different } \\
\text { Services provided } \\
\text { per child }\end{array}$ & $\begin{array}{r}\text { Number of children } \\
\text { receiving Services }\end{array}$ & $\begin{array}{r}\text { Total number of Services } \\
\text { provided }\end{array}$ \\
\hline One service & 233,614 & 233,614 \\
\hline Two services & 13,612 & 27,224 \\
\hline Three or four services & 4,850 & 15,697 \\
\hline Five or six services & 330 & 1,725 \\
\hline More than seven & 44 & 333 \\
services & $\mathbf{2 5 2 , 4 5 0}$ & $\mathbf{2 7 8 , 5 9 3}$ \\
\hline Total & & \\
\hline
\end{tabular}

Source: Children in Need in England 2010 [available at:

http://www.education.gov.uk/rsgateway/DB/STR/d000970/index.shtml]

\footnotetext{
${ }^{35} \mathrm{http}: / /$ www.education.gov.uk/childrenandyoungpeople/strategy/laupdates/a0076006/streamliningthe-children-in-need-census.
} 
Table 6: Number of children by type of services by service provider, at 31 March

\begin{tabular}{|c|c|c|c|c|c|c|c|c|c|}
\hline $\begin{array}{l}\text { Services provided by } \\
\text { service provider }\end{array}$ & $\begin{array}{r}\text { Adoption } \\
\text { support }\end{array}$ & $\begin{array}{r}\text { Aids and } \\
\text { adaptations }\end{array}$ & $\begin{array}{r}\text { Disabled } \\
\text { children's } \\
\text { services } \\
\end{array}$ & $\begin{array}{r}\text { Special } \\
\text { guardianship } \\
\text { support } \\
\text { services }\end{array}$ & $\begin{array}{r}\text { Residence } \\
\text { order } \\
\text { payments }\end{array}$ & $\begin{array}{l}\text { Family } \\
\text { support }\end{array}$ & $\begin{array}{r}\text { Section } \\
24 \\
\text { support }\end{array}$ & $\begin{array}{r}\text { Other care and } \\
\text { accommodation }\end{array}$ & Total \\
\hline $\begin{array}{l}\text { Own Local Authority } \\
\text { provision }\end{array}$ & 2,628 & 1,566 & 19,287 & 1,084 & 3,113 & 194,672 & 14,312 & 14,277 & 250,940 \\
\hline $\begin{array}{l}\text { Other Local Authority } \\
\text { provision }\end{array}$ & 41 & 40 & 567 & 11 & 16 & 3,152 & 163 & 408 & 4,398 \\
\hline Other public provision & 35 & 60 & 882 & $x$ & 16 & 4,569 & $x$ & 719 & 6,601 \\
\hline Private provision & 64 & 456 & 2,211 & 113 & 288 & 3,510 & 1,681 & 2,676 & 10,999 \\
\hline $\begin{array}{l}\text { Voluntary/3rd Sector } \\
\text { provision }\end{array}$ & 45 & 13 & 1,344 & $x$ & 8 & $x$ & 1,241 & 362 & 5,537 \\
\hline Missing/unknown provider & 14 & 0 & 0 & 48 & 12 & $\mathrm{x}$ & $x$ & 41 & 118 \\
\hline Total & 2,827 & 2,135 & 24,291 & 1,269 & 3,453 & 208,425 & 17,708 & 18,483 & 278,593 \\
\hline
\end{tabular}

Source: Children in Need in England 2010 [available at: http://www.education.gov.uk/rsgateway/DB/STR/d000970/index.shtml] 


\section{U.S.}

The National Child Abuse and Neglect System (NCANDS) collects two types of service data. Aggregate data on preventative services are collected by funding source; these services may be received through CPS or through other agencies. These data are based on reporting from a number of different agencies to CPS. Data are also collected on postresponse or post-investigation services which may include in-home services or foster care services. It is acknowledged that collecting such data is challenging because:

Reporting on preventative services depends on the ability and capacity of many hundreds of providers to report data to State agencies, who also face issues of capacity. Reporting on post response services is challenging due to various typologies of services and also the subcontracting of services to private providers, who may also have an array of services under one program' (U.S. Department of Health and Human Services, Administration for Children and Families, Administration on Children, Youth and Families, Children's Bureau 2009, p.83). 
U.S.

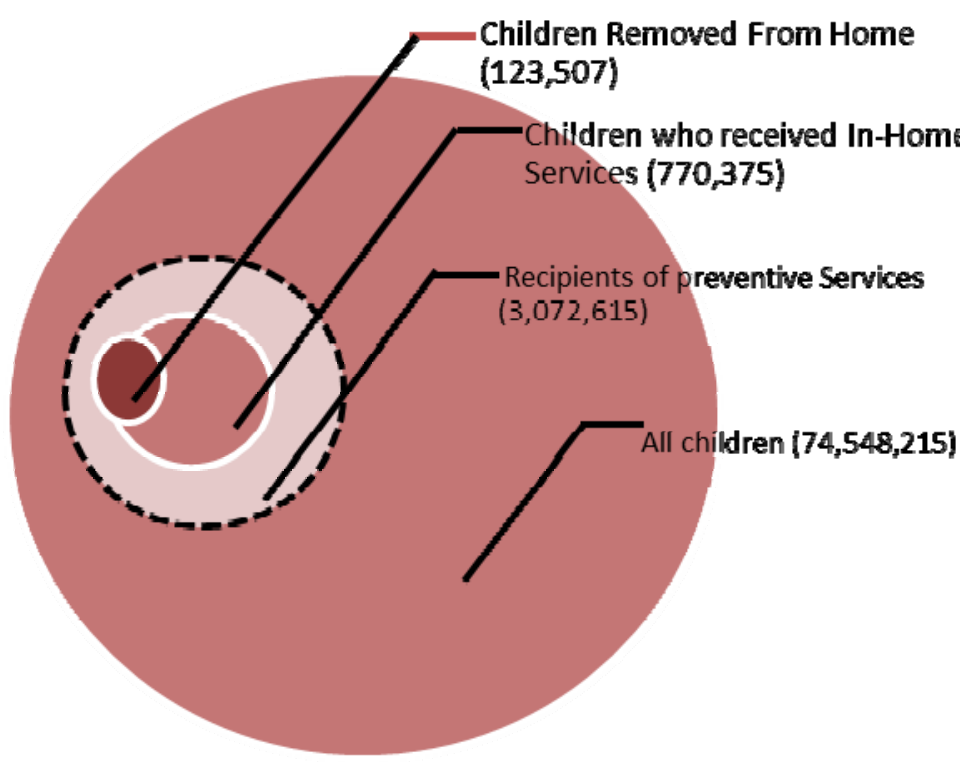

Figure 10: Representation of children receiving state assistance in the U.S., 2009

- All children: estimated number of 0-17 years

- Recipients of preventive services: preventive services are provided to parents whose children are at-risk of abuse and neglect. These services are designed to increase the understanding of parents and other caregivers of the developmental stages of childhood and to improve their child-rearing competencies. Examples include such services as family support, child day care, education and training, employment, housing, and information and referral.

Children may be counted more than once either under a single funding source or across funding sources.

- Children who received in-home services: in-home services include any service that is provided to the family-such as counselling, mental health services, substance abuse services, and other services-while the child is still living at home.

A child is counted each time that a CPS response was completed and in-home services were provided.

- Children removed from home: number of children removed as part of post response services. A child is counted each time that a CPS response was completed and was removed. The child or the family may also have received inhome services. 


\section{Norway}

The diagram below provides an overview of the numbers of families receiving child welfare services in Norway in 2009. More in-depth data on service provision is also published; this facilitates exploration of trends over time.

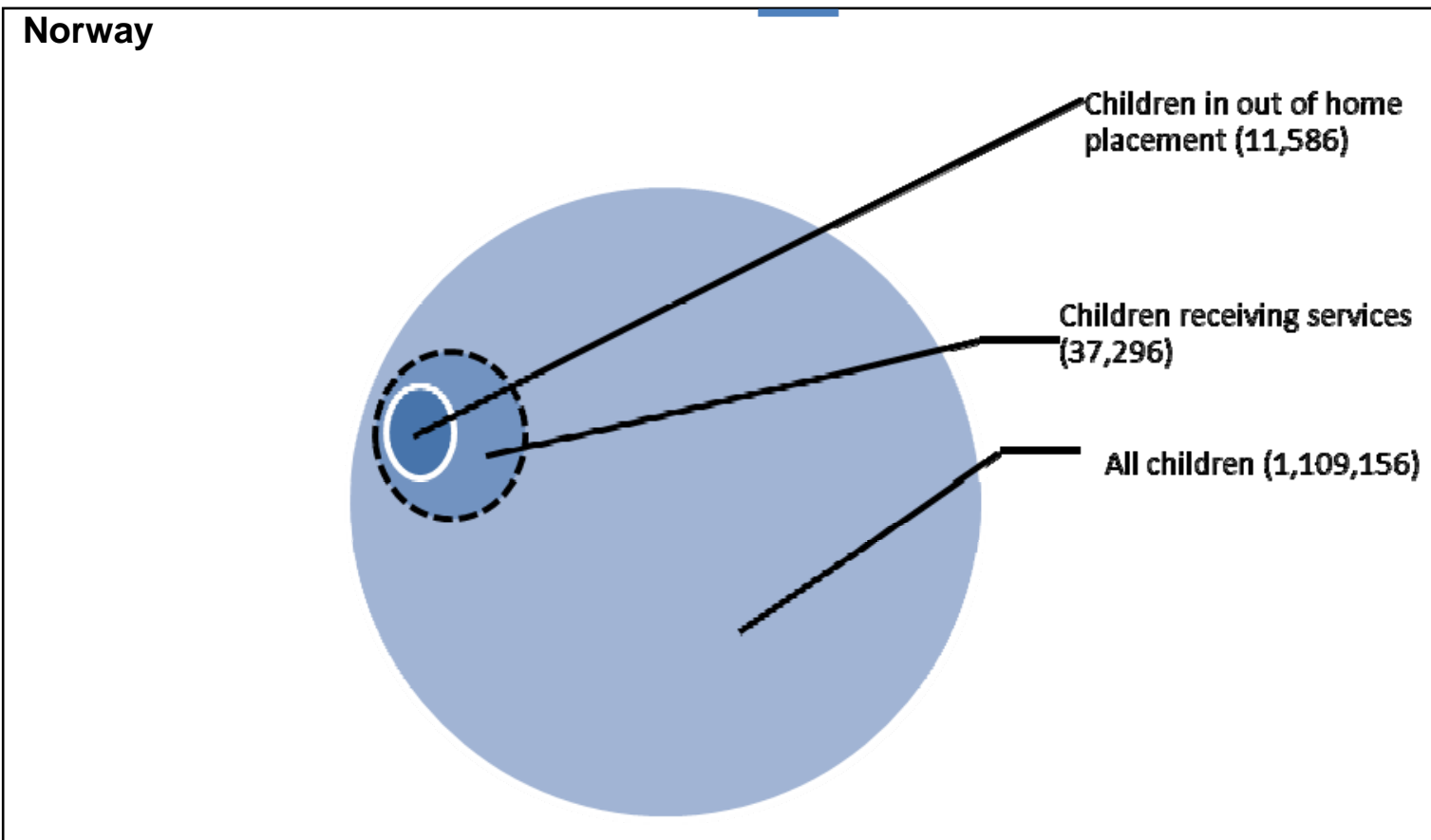

Figure 11: Representation of children receiving child welfare measures in Norway, 2010

- All children: estimated number of 0-17 years.

- Children receiving services: total number of children receiving services (either assistance or care) from Child Welfare Services on 31 December.

- Children in out of home care: number of children in out of home care on 31 December (excluding own housing/housing with support).

Norway collects data on over 20 types of services that are provided to children and families; this is much more detailed than other countries, including England, U.S. and Australia. The data illustrate the potential for exploring changing patterns of service provision over time. 


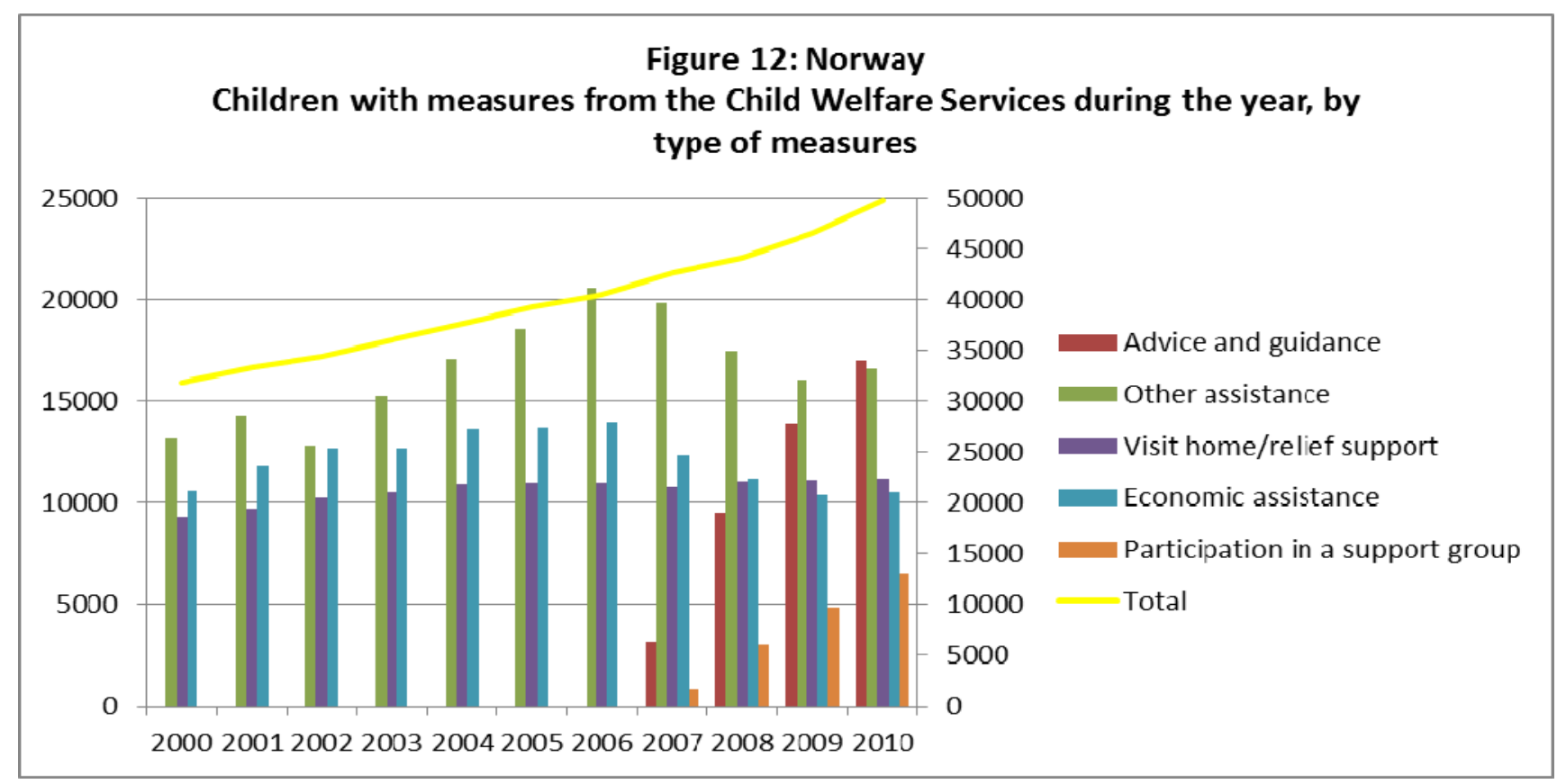

In 2010 the five most frequently used measures were: advice and guidance, other assistance, visit home/relief support, economic assistance and participation in a support group. Figure 12 shows the number of children receiving these services during the year between 2000 and 2010. This reveals that there have been changes in the provision of services over time. The number of families receiving economic assistance has been in decline since 2006, as has the provision of 'other assistance'. In contrast, there has been a significant increase in the numbers receiving advice and guidance: up from 3,148 in 2007 to 17,021 in 2010. Participation in support groups has also been on the rise. The data also reveal that new programmes have been implemented to try and promote the welfare of children; multi-systemic treatment services almost doubled from 385 in 2002 to 770 in 2010.

In conclusion, it is apparent that drawing meaningful comparisons about the services provided to support children and families in different countries is problematic. However, it is also recognised that understanding children's pathways and the child and family welfare services they receive is important to inform local policy development, strategic planning and to understand and assess the outcome of interventions and work is underway to try and address some of these issues (Holmes and Thoburn, unpublished; HM Government, 2011; McDermid, 2008). 


\section{Children in out of home care}

The majority of children who come to the attention of children's services receive no statutory social care services and where services are provided these tend to be offered to children and families at home or in the community. However, some children require out of home placements because the child's own family is unable, even with appropriate support, to provide adequate care for them. In these circumstances the State assumes responsibility for the provision of appropriate alternative care and ensuring their safety, wellbeing and development (General Assembly resolution A/RES/64/142, 2010). However, there are differences between jurisdictions in which children are defined as being in out of home placements. Key variations include whether:

- statistics include children placed under voluntary arrangements or only those on legal orders;

- children placed with their own parents are also classified under Looked After Children;

- temporary stays in respite care are included in the data;

- young offenders are counted as children in out-of-home care ${ }^{36}$; and

- if children cease to be categorised as being in out of home care when they reach legal adulthood.

There are also ideological differences governing perceptions of the role and purpose of care which serve to influence who enters the system and how long they stay (Fernandez and Barth, 2010; Thoburn, 2007; Munro and Stein, 2008).

\section{'In care' population and 'new entrants' to the system}

It is important to differentiate between three sets of data on children in out of home care:

- Those in care on a given date each year (referred to as 'in care', 'snapshot' or 'stock populations');

- Those who enter public care at any time during a 12 month period ('entrant' or 'flow' population);

- Those who experience the in-care service during the year (a combination of the first two but excluding those in care at the start of the year who left during the year to avoid double counting') (Thoburn, 2007, p.13).

\footnotetext{
${ }^{36}$ For example, in Norway out of home care includes children who would be in the youth justice system in England.
} 
Table 7 below shows the number of children in care on a given date in England, Australia, Norway and the U.S. and Figure 13 depicts the 'in care' rates per 1,000 children. Findings reveal an upward trend in the number of children in out of home care over the period 19992010 in every country except the U.S. (where there was a decline from 567,000 in 1999 to 408,452 in 2010). Factors contributing to the falling number of children in out of home care in the U.S. include an increase in the use of 'voluntary' or informal kinship care which diverts children from the formal child welfare system. In addition, efforts have been made to promote timely permanence via adoption or legal guardianship ${ }^{37}$ for children who cannot return to their birth parents (Berrick, 2011; Gilbert, 2012). The scale of the increase in the out of home care populations in the remaining countries varied. The stock population in Australia more than doubled over the period from 15,674 in 1999 to 35,895 in 2010, whereas in England numbers increased fairly gradually in the period 1999-2005, fell slightly in 2006-8 before an unprecedented increase in the wake of media attention surrounding the Peter Connelly case and the Government's subsequent response. In Norway, despite heavy investment and a marked increase in the provision of assistance or in-home services the care population has risen by $48 \%$ in the past ten years. It is also noteworthy that although each country operates in a unique social, political and economic context in 2006-7 the rate per 1,000 of children in out of home care in England, Australia and Norway converged at around five per 1,000 .

${ }^{37}$ The transfers the child's custody from the state to relatives (Gilbert, 2012). 
Table 7: Children in care at a specific date*

\begin{tabular}{|l|l|l|l|l|l|l|l|l|l|l|l|l|}
\hline & $\mathbf{1 9 9 9}$ & $\mathbf{2 0 0 0}$ & $\mathbf{2 0 0 1}$ & $\mathbf{2 0 0 2}$ & $\mathbf{2 0 0 3}$ & $\mathbf{2 0 0 4}$ & $\mathbf{2 0 0 5}$ & $\mathbf{2 0 0 6}$ & $\mathbf{2 0 0 7}$ & $\mathbf{2 0 0 8}$ & $\mathbf{2 0 0 9}$ & $\mathbf{2 0 1 0}$ \\
\hline England & 53,300 & 55,500 & 58,100 & 58,900 & 59,700 & 60,800 & 60,900 & 60,300 & 60,000 & 59,400 & 60,900 & 64,400 \\
\hline Australia & 15,674 & 16,923 & 18,241 & 18,880 & 20,297 & 21,795 & 23,695 & 25,454 & 28,379 & 31,166 & 34,069 & 35,895 \\
\hline Norway & 4715 & 4922 & 5033 & 5225 & 5494 & 5623 & 5776 & 5902 & 6301 & 6406 & 6603 & 6980 \\
\hline U.S. & 567,000 & 552,000 & 545,000 & 533,000 & 520,000 & 517,000 & 513,000 & 510,000 & 491,000 & 463,000 & 423,773 & 408,452 \\
\hline
\end{tabular}

*England: 31 March; Australia: 30 June; Norway: 31 December; U.S.: September 30

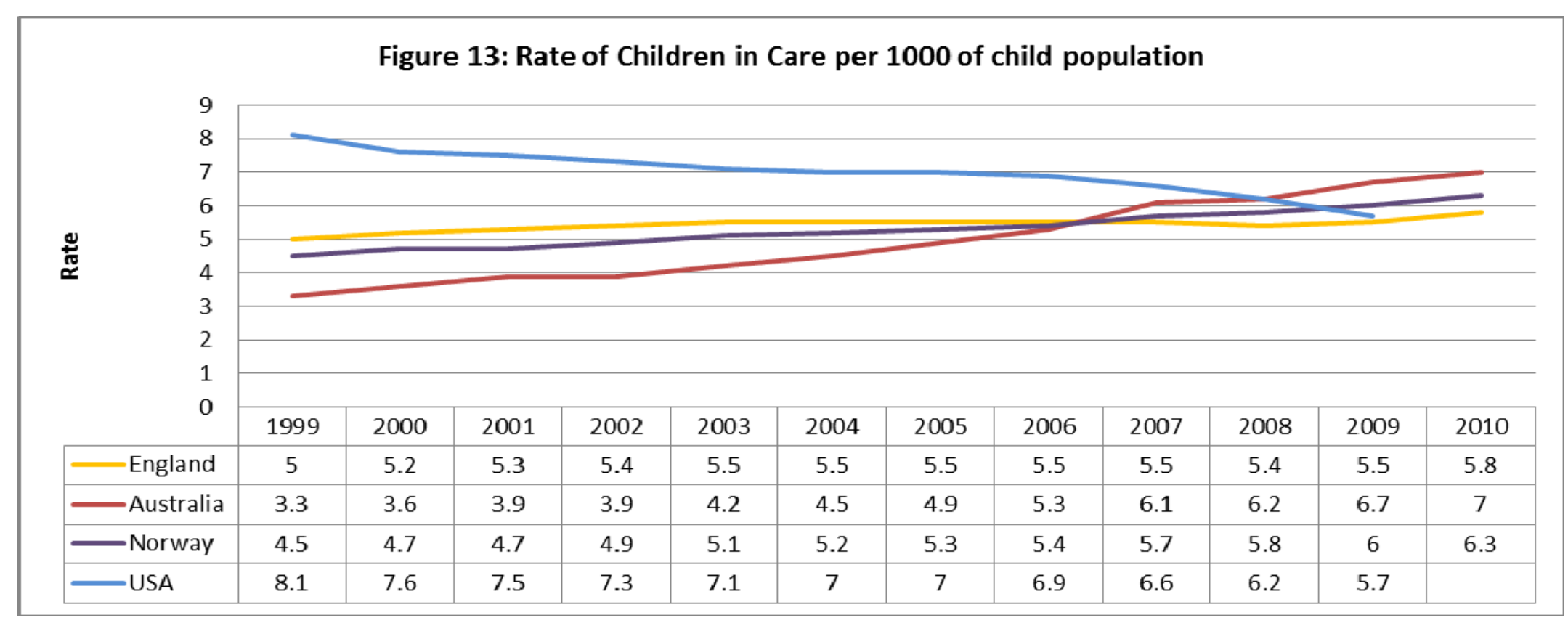


However, it is important to consider these findings with reference to data on who is entering and leaving out of home care. Similarities and differences in legal frameworks and ideological positions on the use of out of home care, as well as levels of need and economic factors will influence the figures and rates per 1,000. Table 8 and Table 9 provide data on new entrants to out of home care in each country.

Table 8: New entrants to out of home care

\begin{tabular}{|c|c|c|c|c|c|c|c|c|c|c|c|c|}
\hline & 1999 & 2000 & 2001 & 2002 & 2003 & 2004 & 2005 & 2006 & 2007 & 2008 & 2009 & 2010 \\
\hline England & 28,400 & 27,900 & 25,000 & 25,200 & 24,700 & 25,000 & 24,500 & 24,600 & 24,000 & 23,300 & 25,700 & 27,800 \\
\hline Australia & 8354 & 8216 & 12,030 & 12,840 & 12,819 & 9,214 & 12,531 & 12,546 & 12,906 & 12,891 & 12,883 & 12,002 \\
\hline Norway & 460 & 381 & 424 & 432 & 503 & 415 & 393 & 427 & 559 & 499 & 448 & 503 \\
\hline U.S. & 293,000 & 293,000 & 296,000 & 303,000 & 296,000 & 305,000 & 311,000 & 303,000 & 293,000 & 273,000 & 255,418 & 254,310 \\
\hline
\end{tabular}

Table 9: New entrants to out of home care (rate per 1,000)

\begin{tabular}{|c|c|c|c|c|c|c|c|c|c|c|c|c|}
\hline & 1999 & 2000 & 2001 & 2002 & 2003 & 2004 & 2005 & 2006 & 2007 & 2008 & 2009 & 2010 \\
\hline England & 2.5 & 2.5 & 2.2 & 2.3 & 2.2 & 2.3 & 2.2 & 2.2 & 2.2 & 2.1 & 2.3 & 2.5 \\
\hline Australia & 1.9 & 1.8 & 2.7 & 2.8 & 2.8 & 2.0 & 2.7 & 2.7 & 2.8 & 2.6 & 2.5 & 2.4 \\
\hline Norway & 0.4 & 0.4 & 0.4 & 0.4 & 0.5 & 0.4 & 0.4 & 0.4 & 0.5 & 0.5 & 0.4 & 0.5 \\
\hline U.S. & 4.2 & 4.1 & 4.1 & 4.2 & 4.1 & 4.2 & 4.2 & 4.1 & 3.9 & 3.7 & 3.4 & \\
\hline
\end{tabular}


Examination of the data on new entrants to out of home care reveals a different picture to that on the in care population and illustrates that the rate of new entrants to out of home care is much lower in Norway than elsewhere (0.5 in 2007 compared to 2.2, 2.8 and 3.7 in England, Australia and the U.S. respectively) but that children tend to stay longer. In Norway, less than $5 \%$ of entrants are aged under two years, which may reflect the strong focus placed on preventative work and the extensive use of in-home services to support families; the system is orientated towards caring for those aged six-17 who account for about $60 \%$ of entrants (Kojan, 2011; Skivenes, 2011). It is not clear whether this is at the expense of protecting very young infants ${ }^{38}$ (Backe-Hansen, personal communication). Skivenes (2011) also identifies that there has been an increase in the number of children in Norway that are placed in out of home care on a voluntary basis, and whilst this was intended to offer temporary care for relatively small numbers of children in practice many of these young people remain in placement for years (although data on the numbers involved and the duration of placements are not available) (p.165; Skivenes, 2002). One reason for this is that maintaining the blood tie between biological parents and children is presumed to be a moral and legal right for both parties and therefore adoption is rarely used in Norway (Skivenes, 2011; Weyland, 1997).

In England, Australia and the U.S., as Table 10 below shows, for many, the time spent in out of home care is short. Exploration of trends over time does also reveal that there has been a reduction in the proportion of children who remain in care for less than year; percentages fell from 58 to $48 \%$ in England; 51 to $46 \%$ in the U.S. and; 40 to 23\% in Australia.

\footnotetext{
${ }^{38}$ According to national statistics there have not be major changes in the age composition of the out of home care population over the last 20 years.
} 
Table 10: Duration of time children remain in out of home care (percentages)

\begin{tabular}{|c|c|c|c|c|c|c|c|c|c|c|c|c|c|c|c|}
\hline Duration $^{39}$ & \multicolumn{3}{|c|}{2001} & \multicolumn{3}{|c|}{2003} & \multicolumn{3}{|c|}{2005} & \multicolumn{3}{|c|}{2007} & \multicolumn{3}{|c|}{2009} \\
\hline & $E$ & $A$ & U.S. $^{40}$ & $E$ & A & U.S. & $E$ & A & U.S. & $E$ & A & U.S. & $E$ & $A$ & U.S. ${ }^{41}$ \\
\hline $\begin{array}{l}\text { Under } 6 \\
\text { months }\end{array}$ & 46 & 27 & 37 & 41 & 24 & 34 & 40 & 22 & 33 & 37 & 16 & 30 & 36 & 12 & 28 \\
\hline $\begin{array}{l}6 \text { months } \\
-1 \text { year }\end{array}$ & 12 & 13 & 14 & 12 & 12 & 16 & 12 & 11 & 17 & 13 & 13 & 18 & 12 & 11 & 18 \\
\hline $\begin{array}{l}13 \text { months } \\
-2 \text { years }\end{array}$ & 14 & 17 & 1 & 16 & 15 & 20 & 15 & 15 & 22 & 17 & 16 & 24 & 17 & 16 & 24 \\
\hline $\begin{array}{l}25 \text { months } \\
-5 \text { years }\end{array}$ & 18 & 24 & 22 & 20 & 28 & 21 & 20 & 26 & 20 & 19 & 25 & 21 & 19 & 28 & 22 \\
\hline $\begin{array}{l}61 \text { months } \\
+\end{array}$ & 10 & 19 & 9 & 11 & 22 & 9 & 13 & 26 & 8 & 14 & 30 & 7 & 16 & 33 & 7 \\
\hline
\end{tabular}

Key: $\mathrm{E}=$ England, $\mathrm{A}=$ Australia, U.S. = United States

It may be that new entrants are remaining in out of home care longer because higher thresholds for entry are in operation. Given that administrations have been investing in early intervention and prevention services which aim to prevent the escalation of problems one might hypothesise that new entrants to the system may be from families with more complex and intractable problems (Ombudsman Victoria, 2011; Parton and Berridge, 2011). There also appears to have been an increase in awareness and public and professional concern about the vulnerability of very young children and improved understanding of the impact of abuse and neglect on early brain development (Bromfield, personal communication; Ward, Brown and Westlake, 2012). This may serve to have influenced decision-making and the duration of time children remain looked after. In 1999 around 10\% of new entrants to out of home care were aged under one, in 2010 16.1, 17.1 and 19\% of entrants to care in the U.S., Australia and England respectively were very young children. In the U.S. and England policy supports timely adoption for those who cannot safely return home but the rising number of very young entrants places pressure on adoption services (see below for further discussion). In Australia ${ }^{42}$ there is not a tradition of domestic adoption which may contribute to an increase in their 'in care' population. The next section explores children's placements whilst they are in care.

\footnotetext{
${ }^{39}$ The timeframes used in each country vary slightly. To facilitate comparisons data from annual reports were cumulated to fit into these categories.

${ }^{40}$ In the data, percentages are calculated only for those children whose data are reported, excluding missing data. Further, the percentages in some tables may not total $100 \%$ due to rounding [source: http://www.acf.hhs.gov/programs/cb/stats_research/afcars/tar/report12.htm].

${ }^{41}$ Ibid.

${ }^{42}$ This is also true of Norway.
} 


\section{Placements}

In each of the four countries under review foster care has been the most common placement type since 1999. In 2010 between 73 and 92 percent of children were in foster placements. However, there are marked differences in the proportion of children in care placed with relatives, kinship carers or friends: $11 \%$ in England, 25\% in the U.S. and $46 \%$ in Australia, although in each of these countries as well as Norway there have been policy initiatives designed to promote the use of these placements. Use of such placements is consistent with the ethos of supporting family relationships and is also welcomed in the context of recruitment and retention difficulties in foster care (Spence, 2004; Clarke, 2009; 2010; Berrick 2011). However, research provides a mixed perspective on the quality of some kinship care placements; concerns have also been raised in some jurisdictions about the remuneration of kinship carers and the levels of support they receive from the state (Clarke, 2010; Farmer and Moyers, 2008; Hunt et al., 2008; Munby Judgment, 2001).

In Australia the use of relative/kinship care is on the rise and the percentage of children in these placements has doubled from 16,369 to 32,887 in the last ten years (although there are variations in its use in different territories). In New South Wales around $60 \%$ of children are placed with relatives and fees and allowances have been aligned with those of nonrelative carers as research revealed that kinship carers tended to be relatively poor financially. There are plans to cease this financial support in light of a consultant's report that it is expensive and that many families are willing to care for their own relatives without state support (Katz, personal communication). In England the use of kinship care has received growing attention over the last decade and local authorities are expected to promote permanence for children by seeking to enable those who cannot live with their parents to remain with members of their extended family (Children Act 1989; Adoption and Children Act 2002; Department for Education, 2011). However, as Figure 14 below illustrates the percentage of looked after children placed with friend and relative carers has remained fairly stable at 10-13\%. Formal kinship arrangements also remained fairly stable in the U.S. ranging from between 23 and 26\% of placements, although it should be acknowledged that there are variations in policy and practice governing kinship care; in some jurisdictions child welfare agencies have sought to identify family members who may be able to offer 'voluntary' care through informal arrangements as a diversion from the child welfare system (Malm and Geen, 2003). 


\section{England}

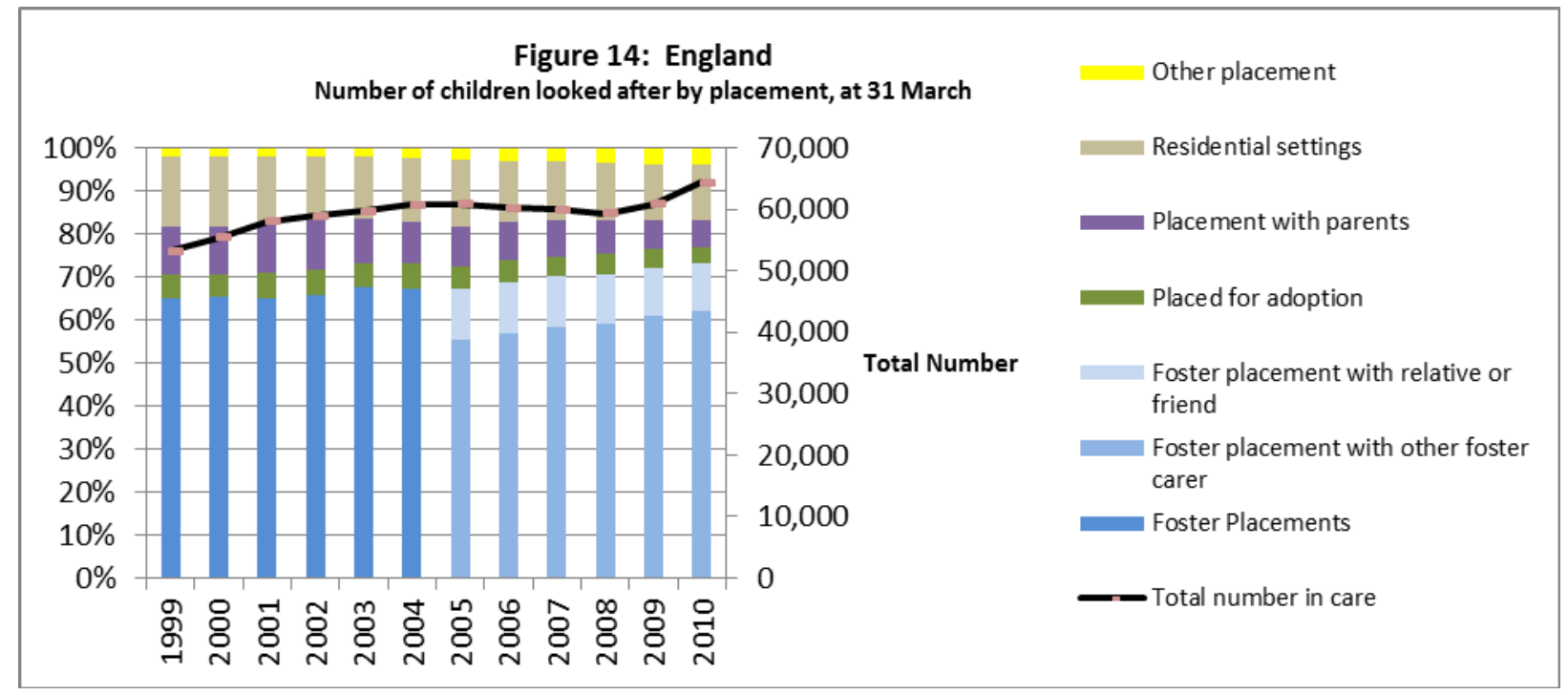

Australia $^{43}$

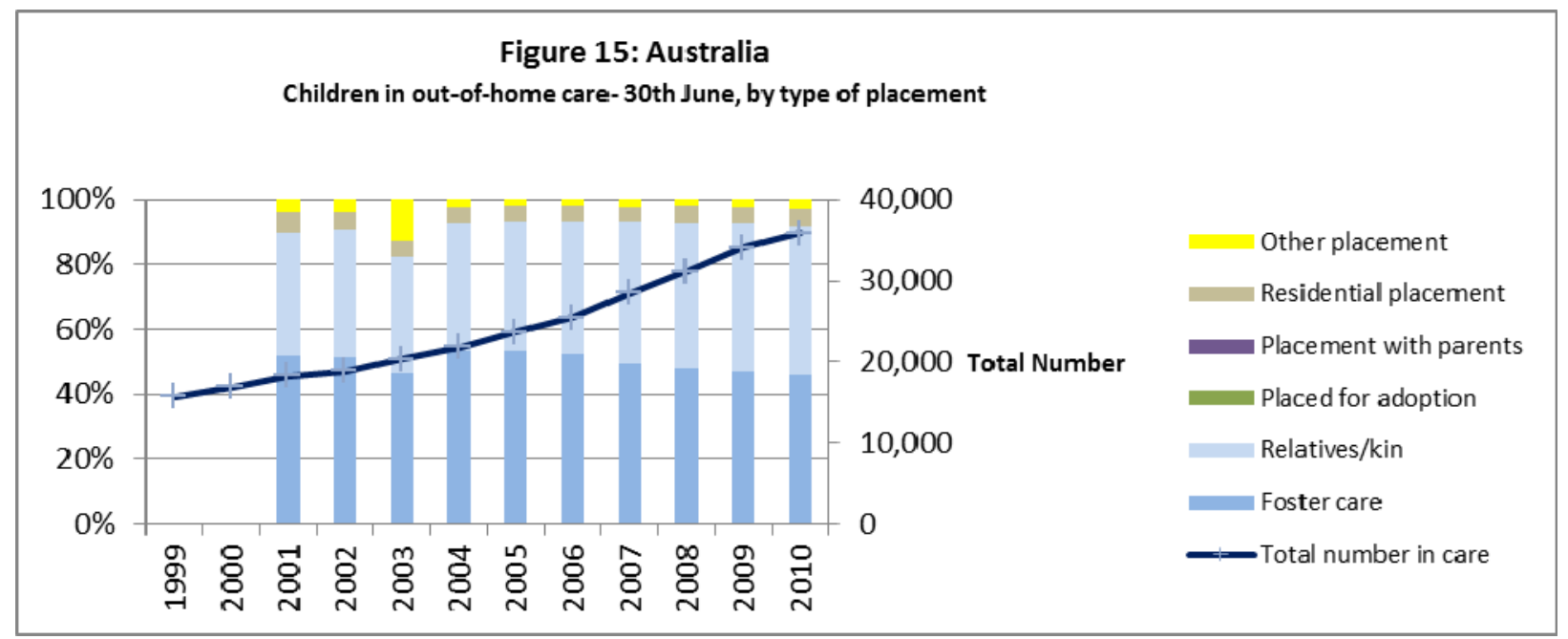

\section{Norway}

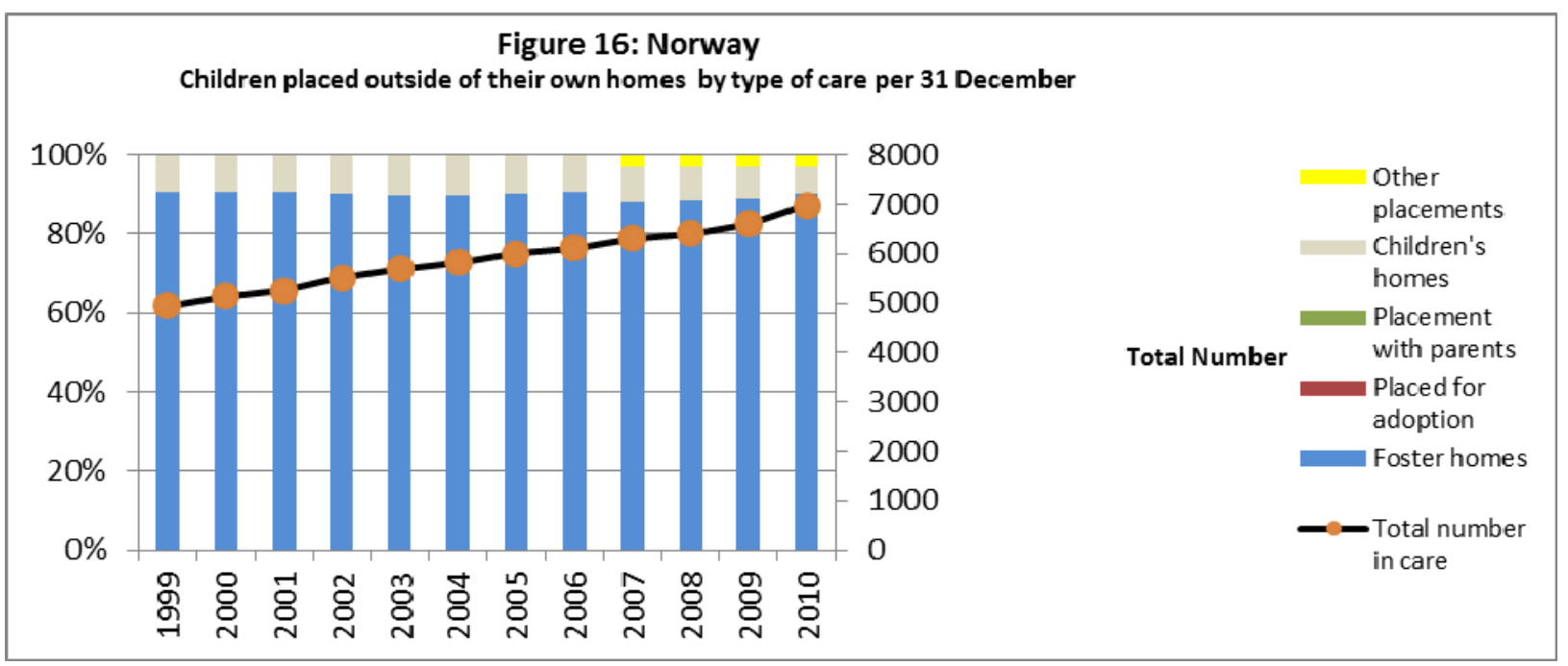

${ }^{43}$ Residential placement: includes Family group homes and Residential care Other placement: includes independent living, other home base care and other 
U.S. ${ }^{44}$

Figure 17: U.S.

Placement settings of children in foster care during FY

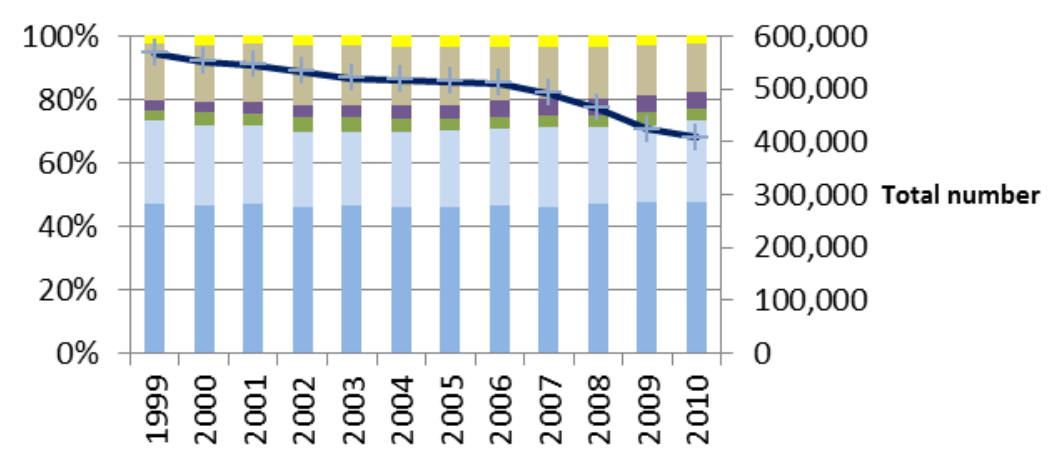

Other placement

Residential placement

Trial Home Visit

Pre-Adoptive Home

Foster Family Home (Relative)

Foster Family Home (Non-Relative)

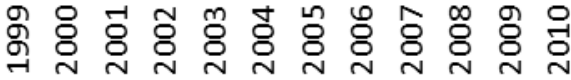

- Total number in care

\footnotetext{
${ }^{44}$ Residential placement: includes Group Home and institution Other placement: includes Runaway and supervised independent living
} 


\section{Leaving out of home care}

\section{Returning home}

England and the U.S. both publish data on the reasons why children and young people leave out of home care. Table 11 provides data on the number and rate per 1,000 children leaving out of home care according to the reason they left. Changes over time are also mapped against key legal and policy developments in figures 18 and 19. The data show that both countries have seen a decline in the numbers and rate per 1,000 children returning to live with their birth parents. In the U.S. 145,341 were reunified in 1999 and this fell to 128,775 in 2010 (2.1 per 1,000 in 1999 and 1.7 in 2010). In England 11,800 returned home during the year ending 2003 compared to 9,800 in 2010 (1.1 per 1,000 in 2003 and 0.9 per 1,000 in 2010). The data also show that over the last ten years the rate of reunification to birth families has been higher in the U.S. than in England (1.7 and 0.9 per 1,000 respectively). This may reflect different thresholds for entry and/or return and it is important to consider these data in the context of outcomes for children. Around $15-30 \%$ of reunifications in the U.S. result in re-entry to care and the more rapidly children return home the more likely re-entry will occur (Courtney, 1995; Fuller, 2005). A small scale study in England exploring life pathways and decision-making for infants suffering, or likely to suffer, significant harm found that around 35 percent were placed away from home but that at age three 43 percent of those who returned home and were still living with their birth families were considered to be at continuing risk of harm from parents whose situations had largely remained unchanged or had deteriorated (Ward, Brown and Westlake, 2012). 
Table 11: England: Reason child placement episode ceased during the year ending 31 March (numbers and rate per 1,000 children)

\begin{tabular}{|c|c|c|c|c|c|c|c|c|c|c|c|c|c|c|c|c|}
\hline \multirow{2}{*}{$\begin{array}{l}\text { England } \\
\text { Adopted }\end{array}$} & \multicolumn{2}{|c|}{2003} & \multicolumn{2}{|c|}{2004} & \multicolumn{2}{|c|}{2005} & \multicolumn{2}{|c|}{2006} & \multicolumn{2}{|l|}{2007} & \multicolumn{2}{|c|}{2008} & \multicolumn{2}{|c|}{2009} & \multicolumn{2}{|c|}{2010} \\
\hline & 3,700 & 0.3 & 3,800 & 0.3 & 3,800 & 0.3 & 3,700 & 0.3 & 3,300 & 0.3 & 3,200 & 0.3 & 3,300 & 0.3 & 3,200 & 0.3 \\
\hline Care taken by another LA & 210 & 0 & 220 & 0 & 230 & 0 & 240 & 0 & 240 & 0 & 190 & 0 & 170 & 0 & 170 & 0 \\
\hline $\begin{array}{l}\text { Returned home to live } \\
\text { with parents or relatives }\end{array}$ & 11,800 & 1.1 & 12,700 & 1.1 & 12,100 & 1.1 & 11,000 & 1 & 10,200 & 0.9 & 9,500 & 0.9 & 9,500 & 0.9 & 9,800 & 0.9 \\
\hline Residence order granted & & & & & & & 930 & 0.1 & 1,000 & 0.1 & 910 & 0.1 & 930 & 0.1 & 1,000 & 0.1 \\
\hline Special guardianship & & & & & & & 70 & 0.1 & 760 & 0.1 & 1,130 & 0.1 & 1,240 & 0.1 & 1,260 & 0.1 \\
\hline Transition to adulthood & 3,510 & 0.3 & 3,290 & 0.3 & 3,560 & 0.3 & 3,830 & 0.3 & 3,840 & 0.3 & 3,980 & 0.4 & 3,730 & 0.3 & 3,770 & 0.3 \\
\hline Sentenced to custody & & & & & & & & & 250 & 0 & 360 & 0 & 350 & 0 & 310 & 0 \\
\hline Other & 5,200 & 0.5 & 5,700 & 0.5 & 6,200 & 0.6 & 6,100 & 0.6 & 5,300 & 0.5 & 5,200 & 0.5 & 5,700 & 0.5 & 5,500 & 0.5 \\
\hline
\end{tabular}

*Adoption: includes application unopposed and consent dispensed with

*Special guardianship: Includes Special guardianship order made to former foster carers and order made to carers other than former foster carers

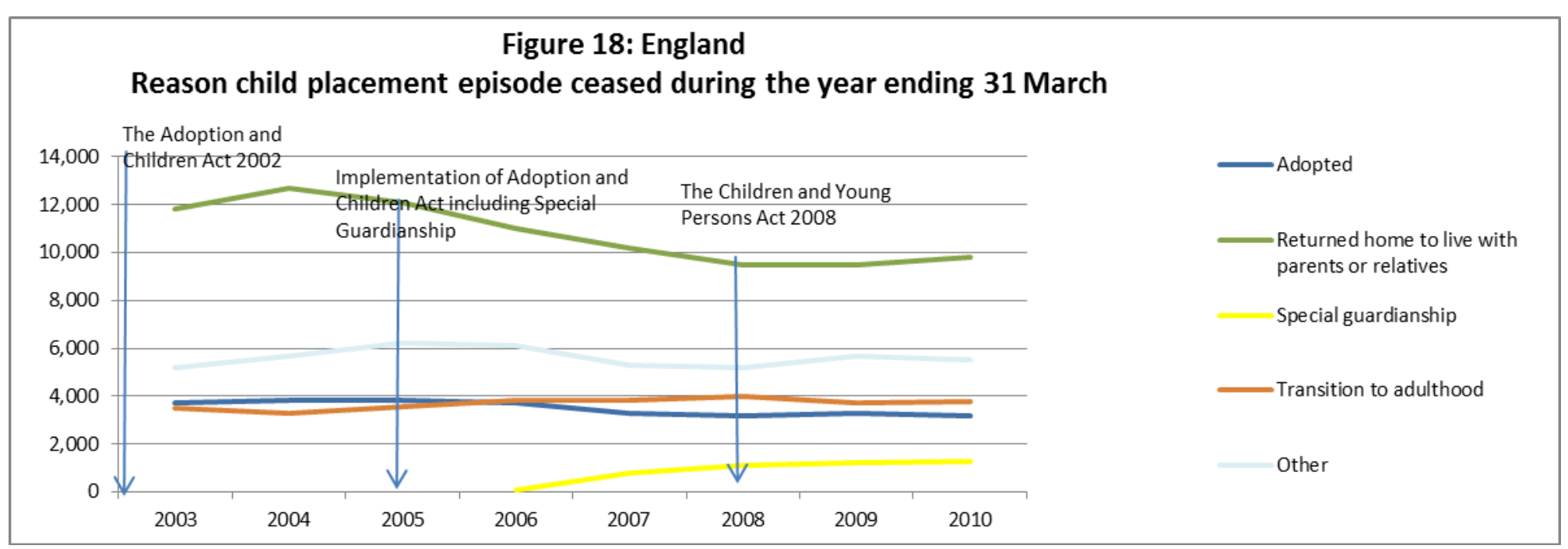




\section{England: Key legislative changes}

The Children (Leaving Care) Act 2000: the central aims of the act were to delay transitions from care, improve the preparation, planning and consistency of support for young people, and strengthen arrangements for financial assistance.

The Adoption and Children Act 2002: modernised the entire legal framework for adoption. The aims of the Act were to improve planning for permanence, increase the number of children adopted from care or otherwise placed permanently out of care, reduce delay in social work and court processes and improve adoption support services.

The Special Guardianship Regulations 2005 (England and Wales): special guardianship provides legal permanence for those children for whom adoption is not appropriate, and gives a special guardian clear responsibility for all aspects of caring for the child and for making decisions to do with his or her upbringing.

The Children and Young Persons Act 2008: the 2008 Act intends to improve the stability of placements and improve the educational experience and attainment of young people in local authority care or those about to leave care. 
Table 12: U.S: Children Exiting Foster Care During the Financial Year (FY) (numbers and rates per 1,000 children)

\begin{tabular}{|c|c|c|c|c|c|c|c|c|c|c|c|c|}
\hline U.S. & 1999 & & 2000 & & 2001 & & 2002 & & 2003 & & 2004 & \\
\hline Adoption & 41,692 & 0.6 & 47,040 & 0.7 & 46,778 & 0.6 & 51,124 & 0.7 & 50,355 & 0.7 & 51,413 & 0.7 \\
\hline Transfer to Another Agency & 7,335 & 0.1 & 7,461 & 0.1 & 7,765 & 0.1 & 7,052 & 0.1 & 6,439 & 0.1 & 6,126 & 0.1 \\
\hline $\begin{array}{l}\text { Reunification with Parent(s) or } \\
\text { Primary Caretaker(s) }\end{array}$ & 145,341 & 2.1 & 156,050 & 2.2 & 154,645 & 2.1 & 158,597 & 2.2 & 155,499 & 2.1 & 151,648 & 2.1 \\
\hline Living with Other Relative(s) & 24,019 & 0.3 & 25,896 & 0.4 & 26,724 & 0.4 & 28,888 & 0.4 & 31,572 & 0.4 & 33,397 & 0.5 \\
\hline Guardianship & 6,713 & 0.1 & 9,043 & 0.1 & 8,325 & 0.1 & 10,535 & 0.2 & 10,959 & 0.2 & 12,519 & 0.2 \\
\hline Emancipation & 18,964 & 0.3 & 20,172 & 0.3 & 19,039 & 0.3 & 20,358 & 0.3 & 22,432 & 0.3 & 23,121 & 0.3 \\
\hline Other & 5936 & 0.1 & 6338 & 0.1 & 5725 & 0.1 & 5446 & 0.1 & 4744 & 0.1 & 4775 & 0.1 \\
\hline
\end{tabular}

\begin{tabular}{|c|c|c|c|c|c|c|c|c|c|c|c|c|}
\hline U.S. & 2005 & & 2006 & & 2007 & & 2008 & & 2009 & & 2010 & \\
\hline Adoption & 51,323 & 0.7 & 50,379 & 0.7 & 52,235 & 0.7 & 54,284 & 0.7 & 55,684 & 0.7 & 52,337 & 0.7 \\
\hline Transfer to Another Agency & 6,440 & 0.1 & 6,683 & 0.1 & 6,118 & 0.1 & 5,195 & 0.1 & 6,291 & 0.1 & 5,096 & 0.1 \\
\hline $\begin{array}{r}\text { Reunification with Parent(s) or } \\
\text { Primary Caretaker(s) }\end{array}$ & 155,608 & 2.1 & 154,103 & 2.1 & 153,868 & 2.1 & 148,340 & 2.0 & 140,061 & 1.9 & 128,775 & 1.7 \\
\hline Living with Other Relative(s) & 31,362 & 0.4 & 30,751 & 0.4 & 27,720 & 0.4 & 23,944 & 0.4 & 21,424 & 0.4 & 20,408 & 0.4 \\
\hline Guardianship & 12,881 & 0.2 & 15,010 & 0.2 & 18,158 & 0.2 & 19,941 & 0.3 & 19,290 & 0.3 & 16,202 & 0.2 \\
\hline Emancipation & 24,407 & 0.3 & 26,517 & 0.4 & 29,730 & 0.4 & 29,516 & 0.4 & 29,471 & 0.4 & 27,829 & 0.4 \\
\hline Other & 4979 & 0.1 & 5558 & 0.1 & 5170 & 0.1 & 3780 & 0.1 & 2558 & 0 & 1837 & 0 \\
\hline
\end{tabular}




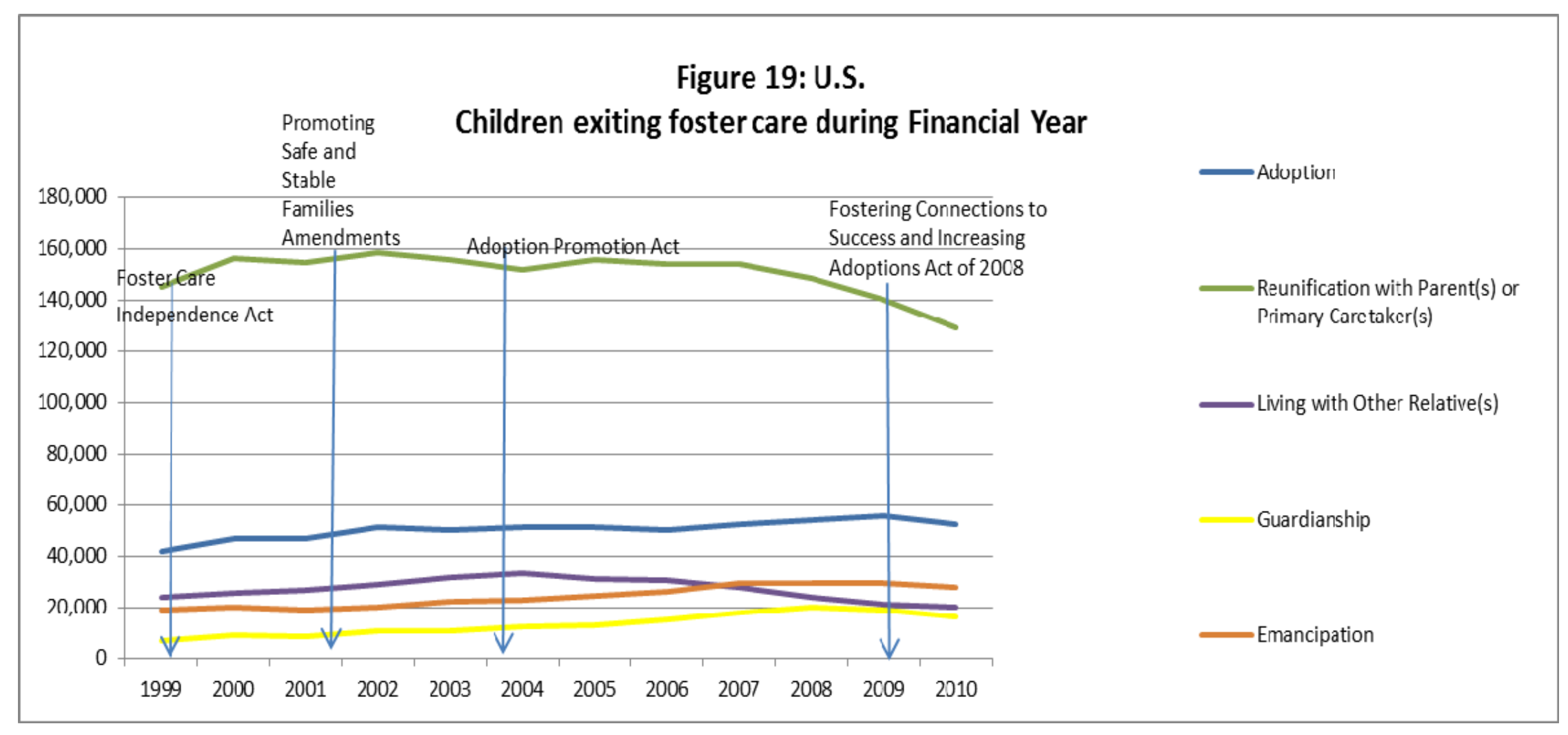




\section{U.S. Key legislative changes}

Promoting Safe and Stable Families Amendments of 2001: To extend and amend the Promoting Safe and Stable Families program, provide new authority to support programs for mentoring children of incarcerated parents, and amend the Foster Care Independent Living program under title IV-E to provide for educational and training vouchers for youth aging out of foster care.

Adoption Promotion Act of 2003: To reauthorize the adoption incentive payments program under part E of title IV of the Social Security Act and for other purposes.

Child and Family Services Improvement Act of 2006: To amend part B of title IV of the Social Security Act to reauthorize the Promoting Safe and Stable Families (PSSF) program, and for other purposes.

Fostering Connections to Success and Increasing Adoptions Act of 2008: To amend parts B and E of title IV of the Social Security Act to connect and support relative caregivers, improve outcomes for children in foster care, improve incentives for adoption, and for other purposes.

\section{Adoption and guardianship}

In both England and the U.S. efforts have been made to promote permanency for children who cannot safely return home. In the U.S. the Adoption and Safe Children Act 1997 (P.L. 105-89) and the 'Adoption 2002 goals' sought to encourage timely permanence and over this period (1998-2002) there was an increase in the number of children adopted from around 36,000 to 51,000 (Berrick, 2011). Since then there have been further legislative changes intended to promote the use of adoption which are mapped on the figure below; in spite of this the adoption rate per 1,000 has remained stable at 0.7 (Barth, Wulczyn and Crea, 2005). It is noteworthy that a similar pattern emerges in England. The Adoption and Children Act 2002 aimed to improve planning for permanence and increase the number of children adopted from care (Department of Health, 2000). Although there was a small increase in the number of children adopted from care in 2003-2005 the rates per 1,000 children adopted have remained constant at 0.3 . The statistical returns demonstrate wide variations in the percentage of children adopted in different authorities and the percentage placed within 12 months of the decision. Research suggests that variations are influenced 
by different views and perspectives on the desirability and feasibility of this form of permanence and that this has an impact upon decision-making processes (Biehal et al., 1995; 1999).

Guardianship offers an alternative permanence arrangement for children who cannot return home; in the U.S. between 3 and 7 percent of children exiting care, leave under these arrangements. This permanence solution was introduced in England under the Adoption and Children Act 2002 and was implemented in 2005 as an alternative permanence solution for those children for whom adoption was not appropriate. Since its inception the number of children who achieve permanence through this means has increased; in 2010, 5 percent $(1,260)$ children ceased to be looked after when a Special Guardianship Order was granted. The statistical returns also show that although orders are being granted for a broad range of children just over half (51\%) were aged under four and more than 65 per cent of orders were made to former foster carers (see also, Wade, Dixon and Richardson, 2010). Early evidence suggests that there are considerable variations between authorities in terms of the financial assistance these carers receive although guidelines suggest that local authorities should have regard to fostering allowances; this has been reinforced following the case of $B v$ London Borough of Lewisham (2008) EWHC 738 (Admin) (Wade, Dixon and Richardson, 2010).

\section{Transitions from care to adulthood}

Although the majority of children exit care to 'permanent' placements 27,829 young people in the U.S. left care to independent living ${ }^{45}$ in 2010 (11 percent of those leaving care). In 2010 in England, 3,770 young people made the transition from care to adulthood (15 percent of those leaving care). These young people have to attempt to simultaneously negotiate the transition to independent living, employment and financial autonomy at a much earlier age and without the level of support that their peers can expect to receive from their family (Stein, 2002) (see Courtney, 2008 and Wade and Munro, 2008 for an overview). Research in both countries has served to highlight that this group are at high risk of social exclusion and poor outcomes including low educational attainment, unemployment, poverty, mental health problems, social isolation, homelessness, instability and involvement in crime (Biehal et al., 1995; 1999; Broad, 1999; Courtney et al., 2001; 2005; Munro, Stein and Ward, 2005; Stein et al., 2000; Stein and Carey, 1986; Stein and Munro, 2008). In recent years efforts have been made to improve outcomes for this group. Policy and practice developments have been implemented in England which aim to delay young people's transitions, enhance preparation and planning, improve the consistency of support and strengthen financial

\footnotetext{
${ }^{45}$ Because they reached the age of majority or graduated from high school.
} 
arrangements to assist this group (Children (Leaving Care) Act 2000; Children and Young Persons Act 2008; Munro et al., 2011b; Munro et al., 2012). This has served to increase the number of 16 and 17 year olds remaining in care. The benefits of permitting young people to remain in foster care up to the age of 21 are also being evaluated (Munro et al., forthcoming). In the U.S. the Fostering Connections to Success and Increasing Adoptions Act 2008 allows states to claim federal reimbursement for the costs of caring for and supervising title IV-E eligible youth ${ }^{46}$ until the age of 21 (rather than 18). Based on observed differences between what happens in one U.S. state (Illinois), which allows young people to remain in foster care until age 21, compared to two other states (lowa and Wisconsin), where foster youth do not have this option estimates suggest a benefit-to-cost- ratio of almost two dollars in increased earnings due to higher rates of bachelor's degree completion for every one dollar spent on foster care beyond age 18 (Peters et al., 2009). They conclude that:

If states adopt a policy of allowing young people to remain in foster care until their $21^{\text {st }}$ birthday...the potential benefits to foster youth and society will more than offset the costs to government (p.9).

\footnotetext{
${ }^{46}$ Must either be completing high school or an equivalent programme, enrolled in postsecondary or vocational school; participating in a programme or activity designed to promote, or remove barriers to employment; employed for at least 80 hours per month or be incapable of doing any of these activities due to a medical condition.
} 


\section{Conclusion}

In the last decade both central and local administrations in England, Australia, Norway and the U.S. have implemented multiple reforms and programmes that have served to change the structure and delivery of services aimed at safeguarding children from harm and promoting their welfare. Despite variations in the social, political and economic contexts in which each operate, research evidence and management information system data have informed policy and practice developments that aim to promote early intervention and prevention to improve outcomes for children and their families. Increased emphasis has also been placed upon partnership working and acknowledging safeguarding children as a shared responsibility rather than one confined to children's social care services. Routinely collected child maltreatment datasets offer a readily accessible source of data to assist in exploring similarities and differences in recognition of and responses to abuse and neglect in various countries and how these have changed over time. They allow countries to benchmark their position against others and provide data which may assist in verifying or refuting claims about how one country is performing in relation to safeguarding children relative to another. However, it is essential that caution is exercised in making claims and drawing conclusions because it is all too easy to come to erroneous conclusions. This reflects the complexities of child welfare systems as well as variations in the data collected, recording practices, definitions of abuse and neglect, thresholds for formal intervention by children's social care services and subsequent systems and processes to respond to these concerns. The culmination of these factors means that making meaningful comparisons is challenging; this is particularly problematic if administrative data are seen in isolation from other sources of information. The study illustrates the value of cross-national dialogue between academics and data experts to promote a more nuanced understanding of trends in child welfare. Findings also highlight the importance of exploring trends in the data with reference to developments in policy, practice, research and evaluations that assist in understanding changes over time.

The study shows that despite variations in the historical orientation of child welfare systems (child protection or family support) over the last decade countries have faced increasing pressures. Some common contributory factors include: socio-economic conditions, family circumstances (including families with complex needs), broadening definitions of abuse and neglect, improved knowledge and awareness of the longstanding impact of maltreatment on children's development, mandatory reporting, child death enquiries and media reporting which influence public and professional responses to concerns that a child is suffering harm, and legislative changes which aim to improve outcomes for children in need. Overall, in 
England, Australia, Norway and the U.S. there has been an upward trend in referrals and assessments to determine whether children are suffering, or likely to suffer, significant harm; but there have been wider variations in substantiation of abuse within and between countries. Evidence suggests that variations in the number and rate of substantiation are due to changes in response to concerns rather than genuine differences in levels of need or child maltreatment. Findings from the Safeguarding Children Research Initiative in England reveal that 'too many children are left for too long or return prematurely to abusive or neglectful families where their welfare is inadequately safeguarded (Davies and Ward, 2012, p.145). In spite of this and policy changes which have aimed to promote family support, with the exception of the U.S. the rate per 1,000 children in out of home care ('in care' or 'stock' population) has been increasing. Although these data show changes over time it is less clear what contribution practice developments and services have had upon trends or outcomes for the children concerned. Whilst countries recognise the value of collecting data on statutory services designed to support children and address difficulties in family functioning, in practice there is still some way to go in establishing robust and comparable data on this ${ }^{47}$. There are also limitations in what can be determined using aggregate datasets. Access and analysis of child-level data provides opportunities for more complex analysis and as Professor Eileen Munro concluded in her review of child protection:

It is crucial that data...enables the effective mapping of the child's journey through the system. Such data can help to inform the development and evaluation of policy by central Government as well as drive improvement and encourage learning and adaptive practice at the local level (Munro, 2011b, p.81).

\footnotetext{
${ }^{47}$ Norway collects much more in-depth data than England, Australia or the U.S.. Data categories in Norway include: neglect, physical abuse, mental abuse, sexual abuse/incest, parents' somatic illness, parents' mental suffering, parents' drug excess, parents' inability of care, parents dead, parents' crime, domestic violence, the child is disabled, the child's psychological problems, the child's drug abuse, the child's behavioural problems, domestic conditions, other reason and unknown reason.
} 


\section{Appendices}

\section{Appendix 1}

\section{Definitions of sexual abuse}

\begin{tabular}{|l|l|}
\hline Australia & $\begin{array}{l}\text { Any act by a person having the care of the child which exposes a child to, } \\
\text { or involves a child in, sexual processes beyond his or her understanding or } \\
\text { contrary to accepted community standards (AlHW, 2010). }\end{array}$ \\
\hline England & $\begin{array}{l}\text { Sexual abuse involves forcing or enticing a child or young person to take } \\
\text { part in sexual activities, not necessarily involving a high level of violence, } \\
\text { whether or not the child is aware of what is happening. The activities may } \\
\text { involve physical contact, including assault by penetration (for example, } \\
\text { rape or oral sex) or non-penetrative acts such as masturbation, kissing, } \\
\text { rubbing and touching outside of clothing. They may also include non- } \\
\text { contact activities, such as involving children in looking at, or in the } \\
\text { production of, sexual images, watching sexual activities, encouraging } \\
\text { children to behave in sexually inappropriate ways, or grooming a child in } \\
\text { preparation for abuse (including via the internet). Sexual abuse is not solely } \\
\text { perpetrated by adult males. Women can also commit acts of sexual abuse, } \\
\text { as can other children (HM Government, 2010). }\end{array}$ \\
\hline U.S. & $\begin{array}{l}\text { It has not proved possible to locate a definition of sexual abuse in Norway, } \\
\text { although statistical data are collected. } \\
\text { A type of maltreatment that refers to the involvement of the child in sexual } \\
\text { activity to provide sexual gratification or financial benefit to the perpetrator, } \\
\text { including contacts for sexual purposes, molestation, statutory rape, } \\
\text { activities. This can include the risk of sexual abuse (U.S. Department of }\end{array}$ \\
\hline Health and Human Services, 2010).
\end{tabular}


Definitions of physical abuse

\begin{tabular}{|l|l|}
\hline Australia & $\begin{array}{l}\text { Any non-accidental physical act inflicted upon a child by a person having } \\
\text { the care of a child (AlHW, 2010). }\end{array}$ \\
\hline England & $\begin{array}{l}\text { Physical abuse may involve hitting, shaking, throwing, poisoning, burning } \\
\text { or scalding, drowning, suffocating, or otherwise causing physical harm to a } \\
\text { child. } \\
\text { Physical harm may also be caused when a parent or carer fabricates the } \\
\text { symptoms of, or deliberately induces, illness in a child (HM Government, } \\
\text { 2010). }\end{array}$ \\
\hline Norway & $\begin{array}{l}\text { It has not proved possible to identify a precise definition of physical abuse, } \\
\text { although data are collected on this issue. Section 30 of the Norwegian } \\
\text { Children Act 1982 (updated, 1987) states: 'The child must not be exposed } \\
\text { to violence, or in any other way be treated so as to harm or endanger his or } \\
\text { her mental or physical health'. This includes corporal punishment by } \\
\text { parents in the home (Sandbaek, Bakketeig and Einarsson, 2008). }\end{array}$ \\
\hline U.S. & $\begin{array}{l}\text { A type of maltreatment that refers to physical acts that caused or could } \\
\text { have caused physical injury to a child, for example bruising. This can } \\
\text { include risk of physical abuse or threatened harm (U.S. Department of } \\
\text { Health and Human Services, 2010). }\end{array}$ \\
\hline
\end{tabular}




\section{Definitions of neglect}

\begin{tabular}{|c|c|}
\hline Australia & $\begin{array}{l}\text { Any serious omissions or commissions by a person having the care of a } \\
\text { child which, within the bounds of cultural tradition, constitute a failure to } \\
\text { provide conditions which are essential for the healthy, physical and } \\
\text { emotional development of a child (AlHW, 2010). }\end{array}$ \\
\hline England & $\begin{array}{l}\text { Neglect is the persistent failure to meet a child's basic physical and/or } \\
\text { psychological needs, likely to result in the serious impairment of the child's } \\
\text { health or development. } \\
\text { Neglect may occur during pregnancy as a result of maternal substance } \\
\text { abuse. Once a child is born, neglect may involve a parent or carer failing to: } \\
\text { - Provide adequate food, clothing and shelter (including exclusion } \\
\text { from home or abandonment). } \\
\text { - } \quad \text { Protect a child from physical and emotional harm or danger. } \\
\text { givers). } \\
\text { Ensure access to appropriate medical care or treatment. } \\
\text { It may also include neglect of, or unresponsiveness to, a child's basic } \\
\text { emotional needs (HM Government, 2010). }\end{array}$ \\
\hline Norway & $\begin{array}{l}\text { It is evident from the statistical data that this includes parents' drug excess, } \\
\text { inability to care and domestic conditions. However, it has not proved } \\
\text { possible to find a full definition. }\end{array}$ \\
\hline U.S. & $\begin{array}{l}\text { - Medical neglect: a type of maltreatment caused by failure by the } \\
\text { caregiver to provide for the appropriate health care of the child } \\
\text { although financially able to do so, or offered financial or other } \\
\text { means to do so. } \\
\text { - Neglect or deprivation of necessities: a type of maltreatment that } \\
\text { refers to the failure by the caregiver to provide needed, age- } \\
\text { appropriate care although financially able to do so or offered } \\
\text { financial or other means to do so. This can include foetal alcohol } \\
\text { syndrome, prenatal substance abuse exposure, abandonment or } \\
\text { educational neglect (U.S. Department of Health and Human } \\
\text { Services, 2010). }\end{array}$ \\
\hline
\end{tabular}




\section{Emotional abuse}

\begin{tabular}{|c|c|}
\hline Australia & $\begin{array}{l}\text { Any act by a person having the care of a child that results in the child } \\
\text { suffering any kind of significant emotional deprivation or trauma (AlHW, } \\
\text { 2010). }\end{array}$ \\
\hline England & $\begin{array}{l}\text { Emotional abuse is the persistent emotional maltreatment of a child such } \\
\text { as to cause severe and persistent adverse effects on the child's emotional } \\
\text { development. } \\
\text { It may involve conveying to children that they are worthless or unloved, } \\
\text { inadequate, or valued only insofar as they meet the needs of another } \\
\text { person. It may include not giving the child opportunities to express their } \\
\text { views, deliberately silencing them or 'making fun' of what they say or how } \\
\text { they communicate. It may feature age or developmentally inappropriate } \\
\text { expectations being imposed on children. These may include interactions } \\
\text { that are beyond the child's developmental capability, as well as } \\
\text { overprotection and limitation of exploration and learning, or preventing the } \\
\text { child participating in normal social interaction. It may involve seeing or } \\
\text { hearing the ill-treatment of another. It may involve serious bullying } \\
\text { (including cyber-bullying), causing children frequently to feel frightened or } \\
\text { in danger, or the exploitation or corruption of children. Some level of } \\
\text { emotional abuse is involved in all types of maltreatment of a child, though it } \\
\text { may occur alone (HM Government, 2010). }\end{array}$ \\
\hline Norway & $\begin{array}{l}\text { It has not proved possible to identify a definition of emotional abuse in } \\
\text { Norway, although statistical data are collected. }\end{array}$ \\
\hline U.S. & $\begin{array}{l}\text { A type of maltreatment that refers to acts or omissions, other than physical } \\
\text { abuse or sexual abuse that caused, or could have caused, conduct, } \\
\text { cognitive, affective, or other mental disorders and includes emotional } \\
\text { neglect, psychological abuse, and mental injury. Frequently occurs as } \\
\text { verbal abuse or excessive demands on a child's performance. This can } \\
\text { include risk of physical or sexual abuse, threatened harm, or domestic } \\
\text { violence (U.S. Department of Health and Human Services, 2010). }\end{array}$ \\
\hline
\end{tabular}




\section{Appendix 2: Child Population}

\section{Australia}

\section{Estimated resident population of children aged under $18^{*^{48}}$}

\begin{tabular}{|c|c|c|c|c|c|c|c|c|c|c|c|c|}
\hline & $\begin{array}{l}\text { Jun- } \\
1999\end{array}$ & $\begin{array}{l}\text { Jun- } \\
2000\end{array}$ & $\begin{array}{l}\text { Jun- } \\
2001\end{array}$ & $\begin{array}{l}\text { Jun- } \\
2002\end{array}$ & $\begin{array}{l}\text { Jun- } \\
2003\end{array}$ & $\begin{array}{l}\text { Jun- } \\
2004\end{array}$ & $\begin{array}{l}\text { Jun- } \\
2005\end{array}$ & $\begin{array}{l}\text { Jun- } \\
2006\end{array}$ & $\begin{array}{l}\text { Jun- } \\
2007\end{array}$ & $\begin{array}{l}\text { Jun- } \\
2008\end{array}$ & $\begin{array}{l}\text { Jun- } \\
2009\end{array}$ & $\begin{array}{l}\text { Jun- } \\
2010\end{array}$ \\
\hline Child population & 4374087 & 4500102 & 4529378 & 4537187 & 4544736 & 4556500 & 4582380 & 4621763 & 4659776 & 5005149 & 5067556 & 5099841 \\
\hline
\end{tabular}

*Source: Australian Bureau of Statistics (ABS)- Time Series Spreadsheets

http://www.abs.gov.au/AUSSTATS/abs@.nsf/DetailsPage/3201.0Jun\%202009?OpenDocument

\section{England}

\section{Population estimates of children aged under 18*}

\begin{tabular}{|c|c|c|c|c|c|c|c|c|c|c|c|c|}
\hline & 1999 & 2000 & 2001 & 2002 & 2003 & 2004 & 2005 & 2006 & 2007 & 2008 & 2009 & 2010 \\
\hline Child population & 11209800 & 11177100 & 11145800 & 11117500 & 11086600 & 11060400 & 11031300 & 10991900 & 10992500 & 11004100 & 11012300 & 11045300 \\
\hline
\end{tabular}

*Source: Office for National Statistics; http://www.statistics.gov.uk/statbase/Product.asp?vlnk=15106

\footnotetext{
${ }^{48}$ The age profile of children was 1-16 years from June 1999 to 2007 and 0 - 17 years from June 2008 to 2009.
} 
Norway

Estimated population of children $0-17$ years of age*

\begin{tabular}{|l|r|r|r|r|r|r|r|r|r|r|r|r|}
\hline & 1999 & 2000 & 2001 & 2002 & 2003 & 2004 & 2005 & 2006 & 2007 & 2008 & 2009 & 2010 \\
\hline $\begin{array}{l}\text { Child } \\
\text { population }\end{array}$ & 1022291 & 1031536 & 1040269 & 1052844 & 1060857 & 1067489 & 1075711 & 1082326 & 1088033 & 1092728 & 1096003 & 1099279 \\
\hline
\end{tabular}

http://statbank.ssb.no/statistikkbanken/Default FR.asp?PXSid=0\&nvl=true\&PLanguage=1\&tilside=selecttable/hovedtabellHjem.asp\&KortnavnWeb=folkemen gde

U.S.

\section{Estimated population of children 0-17 years of age *}

\begin{tabular}{|r|r|r|r|r|r|r|r|r|r|r|r|r|r|r|r|r|r|}
\hline & 1999 & $\mathbf{2 0 0 0}$ & $\mathbf{2 0 0 1}$ & $\mathbf{2 0 0 2}$ & $\mathbf{2 0 0 3}$ & $\mathbf{2 0 0 4}$ & $\mathbf{2 0 0 5}$ & $\mathbf{2 0 0 6}$ & $\mathbf{2 0 0 7}$ & $\mathbf{2 0 0 8}$ & $\mathbf{2 0 0 9}$ & $\mathbf{2 0 1 0}$ \\
\hline Child population & 70199435 & 72293812 & 72941,000 & 72894483 & 73043506 & 73492810 & 73749167 & 74010089 & 74340127 & 74429709 & 74548215 & 74200000 \\
\hline
\end{tabular}

* Source: Federal Interagency Forum on Child and Family Statistics - http://www.childstats.gov/americaschildren/tables.asp 
Appendix 3: Children in substantiations by type of abuse and rate per 1,000
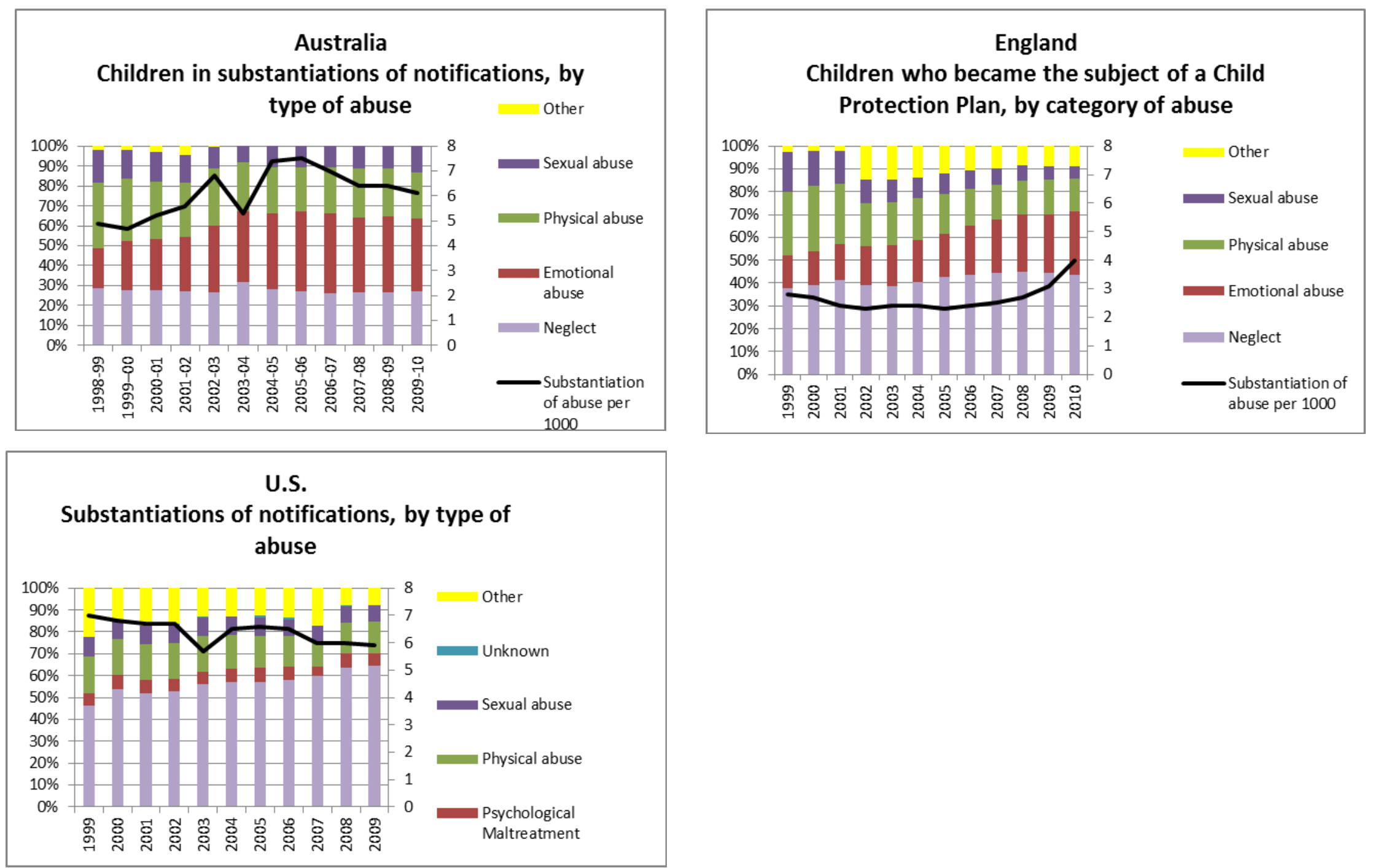


\section{References}

Archard, D. and M. Skivenes (2009) 'Hearing the Child.' Child \& Family Social Work. 14, 4, 391-399.

Association of the Directors of Children's Services (2010) Safeguarding Pressures Project Phase 2: Exploring reasons and effect- Executive Summary. Available at: http://www.adcs.org.uk/download/news/adcs-sg-pressures-p2-exec-summary.pdf

Australian Research Alliance for Children and Youth (2008) Inverting the pyramid. Enhancing systems for protecting children. Melbourne: Allen Consulting Group.

Australian Institute of Health and Welfare (AIHW) 2000. Child protection Australia 1998-99. AlHW cat. no. CWS 11. Canberra: AlHW (Child Welfare Series no. 25). Available at: http://www.aihw.gov.au/publication-detail/?id=6442467141

Australian Institute of Health and Welfare (AIHW) 2001. Child protection Australia 1999-00. AlHW cat. no. CWS 13. Canberra: AlHW (Child Welfare Series no. 27). Available at: http://www.aihw.gov.au/publication-detail/?id=6442467238

Australian Institute of Health and Welfare (AIHW) 2002. Child protection Australia 2000-01. AlHW cat. no. CWS 16. Canberra: AlHW (Child Welfare Series no. 29). Available at: http://www.aihw.gov.au/publication-detail/?id=6442467327

Australian Institute of Health and Welfare (AIHW) 2003. Child protection Australia 2001-02. AlHW cat. no. CWS 20. Canberra: AlHW (Child Welfare Series no. 32). Available at: http://www.aihw.gov.au/publication-detail/?id=6442467444.

Australian Institute of Health and Welfare (2004) Australia's health 2004. Canberra: AlHW.

Australian Institute of Health and Welfare (AIHW) 2005. Child protection Australia 2003-04. AlHW cat. no. CWS 24. Canberra: AlHW (Child Welfare Series no. 36). Available at: http://www.aihw.gov.au/publication-detail/?id=6442467684

Australian Institute of Health and Welfare (AIHW) 2006. Child protection Australia 2004-05. AlHW cat. no. CWS 26. Canberra: AlHW (Child Welfare Series no. 38). Available at: http://www.aihw.gov.au/publication-detail/?id=6442467800

Australian Institute of Health and Welfare (AIHW) 2007. Child protection Australia 2005-06. Child welfare series no. 40. Cat. no. CWS 28. Canberra: AlHW. Available at: http://www.aihw.gov.au/publication-detail/?id=6442467939

Australian Institute of Health and Welfare 2008. Child protection Australia 2006-07. Child welfare series no. 43. Cat. no. CWS 31. Canberra: AlHW. Available at:

http://www.aihw.gov.au/publication-detail/?id=6442468062

Australian Institute of Health and Welfare 2009. Child protection Australia 2007-08. Child welfare series no.45 Cat. no. CWS 33. Canberra: AlHW. Available at:

http://www.aihw.gov.au/publication-detail/?id=6442468200\&tab=2 
Australian Institute of Health and Welfare 2010. Child protection Australia 2008-09. Child welfare series no. 47. Cat. no. CWS 35. Canberra: AlHW. Available at: http://www.aihw.gov.au/publication-detail/?id=6442468325\&tab=2

Australian Institute of Health and Welfare 2011. Child protection Australia 2009-10. Child welfare series no. 51. Cat. no. CWS 39. Canberra: AlHW. Available at: http://www.aihw.gov.au/publication-detail/?id=6442475448\&tab=2

Australian Institute of Health and Welfare (2011) Young Australians: their health and wellbeing 2011. Canberra: AlHW.

Barth, R.P., Wulczyn, F. and Crea, T. (2005) 'From anticipation to evidence: Research on the Adoption and Safe Families Act.' Virginia Journal of Law and Social Policy 12, 371-399.

Berrick, J.D. (2011) 'Trends and Issues in the U.S. Child Welfare System.' In N. Gilbert, N. Parton and M, Skivenes (eds.) (2011a) Child Protection Systems. International Trends and Orientations. Oxford: Oxford University Press.

Berrick, J.D., Barth, R.P., Needell, B. and Jonson-Reid, M. (1998) The tender years. New York: Oxford University Press.

Biehal, N. (1999) 'Having a say: involving young people in research on leaving care.' In M. Barnes and L. Warren (eds) Paths to Empowerment. London: Policy Press.

Biehal, N., Clayden, J., Stein, M. and Wade, J. (1995) Moving On: Young People and Leaving Care Schemes. London: HMSO.

Biehal, N., Ellison, S., Baker, C. and Sinclair, I. (2010) Belonging and Permanence: Outcomes in long term foster care and adoption. London: BAAF.

Broad, B. (1999) 'Young people leaving care: moving towards 'joined up' solutions?' Children and Society 13, 81-93.

Bromfield, L.M. and Higgins, D.J. (2004) 'The limitations of using statutory child protection data for research into child maltreatment.' Australian Social Work 57,1, 19-30.

Bromfield, L. and Holzer, P. (2008) Protecting Australian Children: Analysis of challenges and strategic directions, CDSMC National Approach for Child Protection Project. Canberra: Commonwealth of Australia.

Brookes, C. (2010) Safeguarding Pressures Projects: Results of data collection. London: Association of Directors of Children's Services.

Cashmore, J. and Mendes, P. (2008) 'Australia.' In M. Stein and E.R. Munro (eds) Young People's Transitions from Care to Adulthood: International Research and Practice. London: Jessica Kingsley Publishers.

ChildOnEurope (2009) Guidelines on Data Collection and Monitoring Systems on Child Abuse. Italy: Istituto degli Innocenti. Available at: http://www.childoneurope.org/issues/publications/childabuse guidelines.pdf

Clarke, H. (2009) The Age of Foster Care. London: Fostering Network. 
Clarke, H. (2010) Bursting at the Seams: The impact on fostering services of the rise of children going into care 2009-10. London: Fostering Network.

Cleaver, H. and Walker, S. with Meadows P. (2004) Assessing Children's Needs and Circumstances. London: Jessica Kingsley Publishers.

Cm 5730 (2003) The Victoria Climbié Inquiry: Report of an Inquiry by Lord Laming.. London: The Stationery Office.

Cm 5860 (2003) Every Child Matters. London: The Stationery Office.

Cm 8062 (2011) The Munro Review of Child Protection: Final Report. A Child Centred System. London: The Stationery Office.

Cm 8273 (2012) The Government Response to the Family Justice Review: A system with children and families at its heart. London: The Stationery Office.

Council of Australian Governments (2009) Protecting Children is Everyone's Business.

National Framework for Protecting Australia's Children 2009-2020. Canberra:

Commonwealth of Australia. [available at

http://www.coag.gov.au/coag meeting outcomes/2009-04-

30/docs/child protection framework.pdf]

Courtney, M. (1995) 'Re-entry to foster care of children returned to their families.' Social Services Review 69, 226-241.

Courtney, M., Dworsky, A., Ruth, G., Havlicek, J. and Bost, N. (2005) Midwest Evaluation of the Adult Functioning of Former Foster Youth: Outcomes at age 19. University of Chicago: Chapin Hall Centre for Children.

Courtney, M.E., Pilivan, I., Grogan-Kayor, A. and Nesmith, A. (2001) Foster Youth Transitions to Adulthood: A longitudinal view of youth leaving care. University of Chicago: Chapin Hall Centre for Children.

Courtney, M.E (2008) 'United States.' In M. Stein and E.R. Munro (eds) Young People's Transitions from Care to Adulthood: International Research and Practice. London: Jessica Kingsley Publishers.

Davies, C. and Ward, H. (2012) Safeguarding Children Across Services: Messages from Research. London: Jessica Kingsley Publishers.

Department for Education (1999-2009) Referrals, Assessments and Children and Young People who are the subject of a Child Protection Plan. Available at: http://www.education.gov.uk/rsgateway/catego.shtml\#m9

Department for Education (1999-2010) Children Looked After by Local Authorities in England (including adoption and care leavers) year ending 31 March. Available at: http://www.education.gov.uk/rsgateway/catego.shtml\#m9Referrals

Department for Education (2010) Children In Need in England, including their characteristics and further information on children who were the subject of a child protection plan (Children in Need census, Final). Available at:

http://www.education.gov.uk/rsgateway/DB/STR/d000970/index.shtml 
Department for Education (2011) Family and Friends Care: Statutory Guidance for Local Authorities. [available at

https://www.education.gov.uk/publications/eOrderingDownload/Family\%20and\%20Friends\% 20Care.pdf

Department for Education and Skills (2006) What to do if you're Worried a Child is being Abused? London: Department for Education and Skills.

Department of Health (1995) Child Protection: Messages from Research. London: HMSO.

Department of Health (2000) Adoption, a new approach - a White Paper Cm 5017. London: Department of Health.

Department of Health (2003) What to do if you're worried a child is being abused? London: Department of Health.

Department of Health, Department for Education and Employment and the Home Office (2000) Framework for the Assessment of Children in need and their Families. London: The Stationery Office.

Department of Health, Home Office, and Department for Education and Employment (1999) Working Together to Safeguard Children: A guide to interagency working to safeguard and promote the welfare of children. London: The Stationery Office.

Dobrowolsky, A. (2002) 'Rhetoric versus reality: The figure of the child and New Labour's strategic "social investment state".' Studies in Political Economy, Autumn, 43-73.

Drake, B. and Johnson-Reid, M. (1999) 'Some thoughts on the increasing use of administrative data in child maltreatment research.' Child Maltreatment 4, 308-314.

English, D.J., Brandford, C. and Coghlan, L. (2000) 'Data-based organisazational change: the use of administrative data to improve child welfare programs and policies.' Child Welfare League of America LXXIX, 500-515.

Euser, E.M., IJzendoorn, M., Prinzie, P. and Bakermans-Kranenburg, M.J. (2010)

Prevalence of Child Maltreatment in the Netherlands. Child Maltreatment 15, 5-17.

Farmer, E. and Moyers, S. (2008) Fostering Effective Family and Friends Placements. London: Jessica Kingsley Publishers.

Farmer, E. and Dance, C. with Beecham, J, Bonin, E and Ouwejan, D. (2010) An Investigation of Family Finding and Matching in Adoption - Briefing Paper. Research Brief DFE RBX-10-05. London: Department for Education.

Family Violence Clearing House (2009) Family Violence Statistics Fact Sheet [assessed May 26, 2011 from

http://www.nzfvc.org.nz/sites/default/files/Statistics\%20Fact\%20Sheet\%20December\%2020 09.pdf] 
Fawcett, B., Featherstone, B. and Goddard, J. (2003) From the Womb to Workplace: Child Welfare under New Labour. Paper presented to the Annual Conference of the Social Policy Association, 15 July. Middlesbrough: University of Teesside.

Fernandez, E. and Barth, R. (2010) How Does Foster Care Work? International Evidence on Outcomes. London: Jessica Kingsley Publishers.

Finkelhor, D., Jones, L. and Shattuck, A. (2011) Updated Trends in Child Maltreatment, 2009. Durham, NH: Crime Against Children Research Centre.

Fluke, J.D., Edwards, M., Kutzler, P., Kuna, J. and Tooman, G. (2000) 'Safety, permanency and in-home services: applying administrative data.' Child Welfare League of America LXXIX, 573-595.

France, A., Munro, E.R. and Waring, A. (2010) The Evaluation of Arrangements for Effective Operation of the New Local Safeguarding Children Boards in England: Final Report. DFERR027. London: Department for Education.

Freymond, N. and Cameron, G. (eds.) (2006) Towards Positive Systems of Child and Family Welfare. Canada: University of Toronto Press.

Gatehouse, M., Ward, H., and Holmes, L. (2008) Developing Definitions of Local Authority Services and Guidance for the New Children in Need Census, Final report to the Department for Children Schools and Families. London: Department of Children, Schools and Families.

Gilbert, N. (1997) Combatting Child Abuse: International perspectives and trends. New York: Oxford University Press.

Gilbert, N. (2012) 'A comparative study of child welfare systems: Abstract orientations and concrete results.' Children and Youth Services Review 34, 532-536.

Gilbert, R., Kemp, A., Thoburn, J., Sidebotham, P., Radford, L., Glaser, D. and MacMillan, H.L. (2009a) 'Recognising and responding to child maltreatment.' The Lancet 372, 167-80.

Gilbert, R.E., Spatz Widom, C., Browne, K., Fergusson, D., Webb, E. and Janson, S. (2009b) 'Burden and consequences of child maltreatment in high-income countries.' The Lancet 373 , 68-81.

Gilbert, N., Parton, N. and Skivenes, M. (eds.) (2011a) Child Protection Systems. International Trends and Orientations. Oxford: Oxford University Press.

Gilbert, N., Parton, N. and Skivenes, M. (2011b) 'Changing patterns of response and emerging orientations.' In N. Gilbert, N. Parton and M. Skivenes (eds.) Child Protection Systems. International Trends and Orientations. Oxford: Oxford University Press.

Harries, M. and Clare, M. (2002) Mandatory reporting of child abuse: Evidence and options. Perth: Discipline of Social Work and Social Policy, University of Western Australia.

Healy, K. and Oltedal, S. (2010) 'An institutional comparison of child protection systems in Australia and Norway focused on workforce retention.' Journal of Social Policy 39, 255-274. 
Hetherington, R. (2006) 'Learning from difference: Comparing child welfare systems.' In N. Freymond and G. Cameron (eds)Towards Positive Systems of Child and Family Welfare. University of Toronto Press: Toronto, 27- 50.

Hetheringtron, R., Cooper, A., Smith, P. and Wilford, G. (1997) Protecting children. Messages from Europe. Lyme Regis: Russell House Publishing.

Higgins, D. and Katz, I. (2008) 'Enhancing service systems for protecting children. Promoting child wellbeing and child protection reform in Australia.' Family Matters 80, 44-50. Australian Institute of Family Studies.

HM Government (2006b) What to do if you're worried a child is being abused? London: The Stationery Office.

HM Government. (2009) The protection of children in England: action plan. The government's response to Lord Laming. London, The Stationery Office.

HM Government (2010) Working Together to Safeguard Children: A Guide to Inter-Agency Working to Safeguard and Promote the Welfare of Children. London: Department for Children, Schools and Families.

Holmes, L. and McDermid, S. (2012) Understanding the Costs of Child Welfare. London: Jessica Kingsley Publishers.

Holmes, L., McDermid, S. and Sempik, J. (2010) The Cost of Short Break Provision. Report to the Department for Children, Schools and Families. Loughborough: Centre for Child and Family Research, Loughborough University.

Holmes, L., McDermid, S., Soper, J., Sempik, J. and Ward, H. (2010) Extension of the Cost Calculator to include Cost Calculations for all Children in Need (research brief). London: Department for Education.

Holmes, L., Munro, E.R. and Soper, J. (2010) Calculating the cost and capacity implications for local authorities implementing the Laming (2009) recommendations. London: Local Government Association. Available at: http://www.lga.gov.uk/lga/aio/9387423

Holmes, L. and Thoburn, J. (unpublished) The contribution to child welfare research of robust administrative data on children in need. Discussion paper from Lisa Holmes and June Thoburn for the CiN review group meeting.

Hunt, J., Waterhouse, S. and Lutman, E. (2008) Keeping them in the Family: Children Placed in Kinship Care Through Care Proceedings. London: BAAF.

ISPCAN (2010) 'World Perspectives on Child Abuse: Ninth edition.' In Gray J. (ed) Denver: International Society for Prevention of Child Abuse and Neglect.

Iwaniec, D. (1995) The Emotionally Abused and Neglected Child. Chichester: Wiley.

Kojan, B.H. (2011) Norwegian child welfare services: a successful program for protecting and supporting vulnerable children and parents? Australian Social Work.

doi:10:1080/0312407x.2010.538069 
Kosanovich, A. and Joseph, R. M. (2005) Child welfare consent decrees: Analysis of thirtyfive court actions from 1995 to 2005. Washington, DC: Child Welfare League of America and American Bar Association.

Lamont, A. (2011) Child Abuse and Neglect Statistics. Australian Institute of Family Studies.

Lister, R. (2003) 'Investing in the citizen-workers of the future: Transformations in citizenship and the state under New Labour.' Social Policy and Administration 37, 5, 427-443.

Lister, R. (2006) 'An agenda for children: Investing in the future or promoting well-being in the present?' In J. Lewis (ed.) Children, changing families and welfare states. Cheltenham: Edward Elgar.

Lord Laming (2009) The Protection of Children in England: A Progress Report. HCC 330 London: The Stationery Office.

Lonne, B., Parton, N., Thomson, J. and Harries, M. (2008) Reforming child protection. London: Routledge.

Malm, K. and Geen, R. (2003) When child welfare agencies only rely on voluntary kinship placements. Ni A-61. Washington DC: Urban Institute.

Mansell, J., Ota, R., Erasmus, R. and Marks, K. (2011) 'Reframing child protection: A response to a constant crisis of confidence in child protection.' Children and Youth Services Review 33, 2076-2086.

Mathews, B. and Kenny, M.C. (2008) 'Mandatory reporting legislation in the United States, Canada and Australia: A cross-jurisdictional review of key features, differences and issues.' Child Maltreatment 13, 50-63.

McDermid, S. (2008) 'The nature and availability of child level data on children in need for use by Children's Services practitioners and managers.' Research, Policy and Planning 26, 3, 183-192.

Ministry of Social Development (2006) Children at increased risk of death from maltreatment and strategies for prevention. [assessed March 8, 2011 from http://www.msd.govt.nz/documents/about-msd-and-our-work/newsroom/mediareleases/news/2006/pr-2006-07-27-2-child-death-from-maltreatment.pdf]

Ministry of Social Development (2010) Recognising and responding to child neglect in New Zealand. Centre for Social Research and Evaluation. Wellington, New Zealand: Ministry of Social Development.

Munro, E. (2011) The Munro Review of Child Protection: Interim Report: A Child's Journey. London: Department for Education.

Munro, E.R., Brown, R., Sempik, J. and Ward, H. (2011a) Scoping Review to Draw together Data on Child Injury and Safeguarding and to Compare the Position of England and the UK with that in Other Countries. Report to Department for Education. London: Department for Education. 
Munro, E.R., Lushey, C., Ward, H. and NCAS with Soper, J., McDermid, S., Holmes, L., Beckhelling, J. and Perren, K. (2011b) Evaluation of the Right2BCared4 Pilots: Final report. London: Department for Education.

Munro, E. R., Stein, M. and Ward, H. (2005) 'Comparing how different social, political and legal frameworks support or inhibit transitions from public care to independence in Europe, Israel, Canada and the United States.' International Journal of Child Welfare 4,191-201.

Munro, E.R., Maskell-Graham, D., Ward, H. and National Care Advisory Service (2012) Staying Put 18+ Family Placement pilot. Final report. London: Department for Education.

Munro, E.R., Brown, R. and Manful, E. (2011) Safeguarding children statistics: the availability and comparability of data in the UK. Research Brief. DFE-RB153. London: Department for Education.

O'Donnell, M., Scott, D. and Stanley, F. (2008) 'Child abuse and neglect: Is it time for a public health approach?' Australian and New Zealand Journal of Public Health 32,4, 325-330.

OECD (2011) Doing Better for Families. OECD Publishing.

Parton, M. and Berridge, D. (2011)'Child protection in England.' In N. Gilbert, N. Parton, M. Skivenes (eds) Child Protection Systems: International Trends and Orientations. Oxford: Oxford University Press.

Peters, C.M., Dworsky, A., Courtney, M.E. and Pollack, H. (2009) Extending foster care to age 21: Weighing the costs to government against the benefits to youth. Chapin Hall Issue Brief. June. Chicago: Chapin Hall at the University of Chicago.

Platt, D. (2005) 'Investigation or Initial Assessment of Child Concerns? The impact of the refocusing initiative on social work practice.' British Journal of Social Work 36, 2, 267 - 281.

Richards, A. and Tapsfield, R. (2003) Funding Family and Friends Care: The Way Forward. London: Family Rights Group.

Schene, P. (2006) 'Forming and sustaining partnerships in child and family welfare: the American experience.' In N. Freymond and G. Cameron (eds)Towards Positive Systems of Child and Family Welfare. University of Toronto Press: Toronto.

Schwartz-Kenney, B. M., McCauley, M. and Epstein, M. (2001) Child Abuse: A Global View. Westport, CT: Greenwood.

Scott, D. (2005) 'Towards a public health model of child protection in Australia.'

Communities, Children and Families Australia 1,1, 9-16.

Simpson, D.G., Imrey, P.B., Geling, O. and Butkus, S. (2000) 'Statistical estimation of child abuse rates from administrative databases.' Children and Youth Services Review 22, 951971.

Skivenes, M. (2011) 'Norway: towards a child-centric perspective.' In N. Gilbert, N. Parton, M. Skivenes (eds.) (2011a) Child Protection Systems. International Trends and Orientations. Oxford: Oxford University Press.

Spence, N. (2004) Kinship Care in Australia. Child Abuse Review, 13: 263-276 
Statistics Norway (2000 - 2009) Child Welfare Data

Available at: Statistics Norway http://www.ssb.no/english/subjects/03/03/.

Stein, M. and Carey, K. (1986) Leaving Care. Oxford: Blackwells.

Stein, M., Pinkerton, J. and Kelleher, P. (2000) 'Young people leaving care in England, Northern Ireland and Ireland: a comparative research perspective.' European Journal of Social Work 3, 3, 235-246.

Stein, M. (2002) 'Leaving Care.' In D. McNeish, T. Newman and H. Roberts. (eds.) What works for children. UK: Open University.

Stein, M. and Munro, E.R. (2008) Young People's Transitions from Care to Adulthood: International Research and Practice. London: Jessica Kingsley Publishers.

Storo, J. (2008) 'Norway.' In M. Stein and E.R. Munro (eds) Young People's Transitions from Care to Adulthood: International Research and Practice. London: Jessica Kingsley Publishers.

Thoburn, J. (2007) Globalisation and child welfare: some lessons from a cross-national study of children in out-of-home care. Norwich: University of East Anglia. Available at: http://www.uea.ac.uk/polopoly_fs/1.103398!globalisation\%201108.pdf

Tjelflaat, T. (2001) 'Child protection in Norway: Changing ideologies.' Journal of Social Work 2, 82-90.

U.S. Department of Health and Human Services, Administration for Children and Families, Administration on Children, Youth and Families, Children's Bureau. (1999 - 2009a) Child Abuse \& Neglect Research Child Maltreatment Reports 1999 - 2009. Available at: U.S. Department of Health and Human Services, Administration for Children and Families, Administration on Children, Youth and Families, Children's Bureau http://www.acf.hhs.gov/programs/cb/stats research/index.htm\#afcars

U.S. Department of Health and Human Services, Administration for Children and Families, Administration on Children, Youth and Families, Children's Bureau (1999-2009b) Adoption and Foster Care Statistics Adoption and Foster Care Analysis and Reporting System Data. Available at: U.S. Department of Health and Human Services, Administration for Children and Families, Administration on Children, Youth and Families, Children's Bureau http://www.acf.hhs.gov/programs/cb/stats_research/index.htm\#afcars

US Department of Health and Human Services, Administration on Children youth and Families (2008) Child Maltreatment 2006. Washington, DC: US Government Printing Office.

Wade, J., Dixon, J. and Richardson, A. (2010) Special Guardianship in Practice. London: BAAF.

Wade, J. and Munro, E.R. (2008) 'United Kingdom.' In M. Stein and E.R. Munro (eds) Young People's Transitions from Care to Adulthood: International Research and Practice. London: Jessica Kingsley Publishers.

Ward, H., Brown, R. and Westlake, D. (2012) Safeguarding Babies and Very Young Children from Abuse and Neglect. London: Jessica Kingsley Publishers. 
Ward, H., Holmes, L., Moyers, S., Munro, E. R. and Poursanidou, D. (2004) Safeguarding Children: A scoping study of research in three areas. Final report to the Department for Education and Skills. Loughborough: Centre for Child and Family Research, Loughborough University

Ward, H., Holmes, L. and Soper, J. (2008) Costs and Consequences of Placing Children in Care. London: Jessica Kingsley Publishers.

Weyland, I. (1997) 'The blood tie: raised to the status of a presumption.' Journal of Social Welfare and Family Law 19(2), 173-188.

Williams, F. (2004) 'What matters is who works: Why every child matters to New Labour, Commentary on the DfES Green Paper "Every Child Matters".' Critical Social Policy 24, 3, 406-427.

Wood, J. (2008) Report of the Special Commission of Inquiry into Child Protection Services in NSW: Executive Summary and Recommendations. NSW: State of New South Wales.

Yampolskaya, S. and Banks, S. M. (2006) 'An assessment of the extent of child maltreatment using administrative databases.' Assessment 13, 342-355.

\section{Family Court Cases}

$\mathrm{R}$ (on the application of $\mathrm{L}$ and others) $\mathrm{v}$. Manchester City Council; $\mathrm{R}$ (on the application of $\mathrm{R}$ and another) v. Same [2001] EWHC Admin 707, CO/3954/2000, CO/965/2001. 
Ref: DFE-RR198

ISBN: 978-1-78105-086-6

(C) E.R Munro and E Manful, Childhood Wellbeing Research Centre

March 2012 